In cooperation with

SUFFOLK COUNTY WATER AUTHORITY

\title{
Simulated Effects of Pumping and Drought on Ground-Water Levels and the Freshwater- Saltwater Interface on the North Fork, Long Island, New York
}

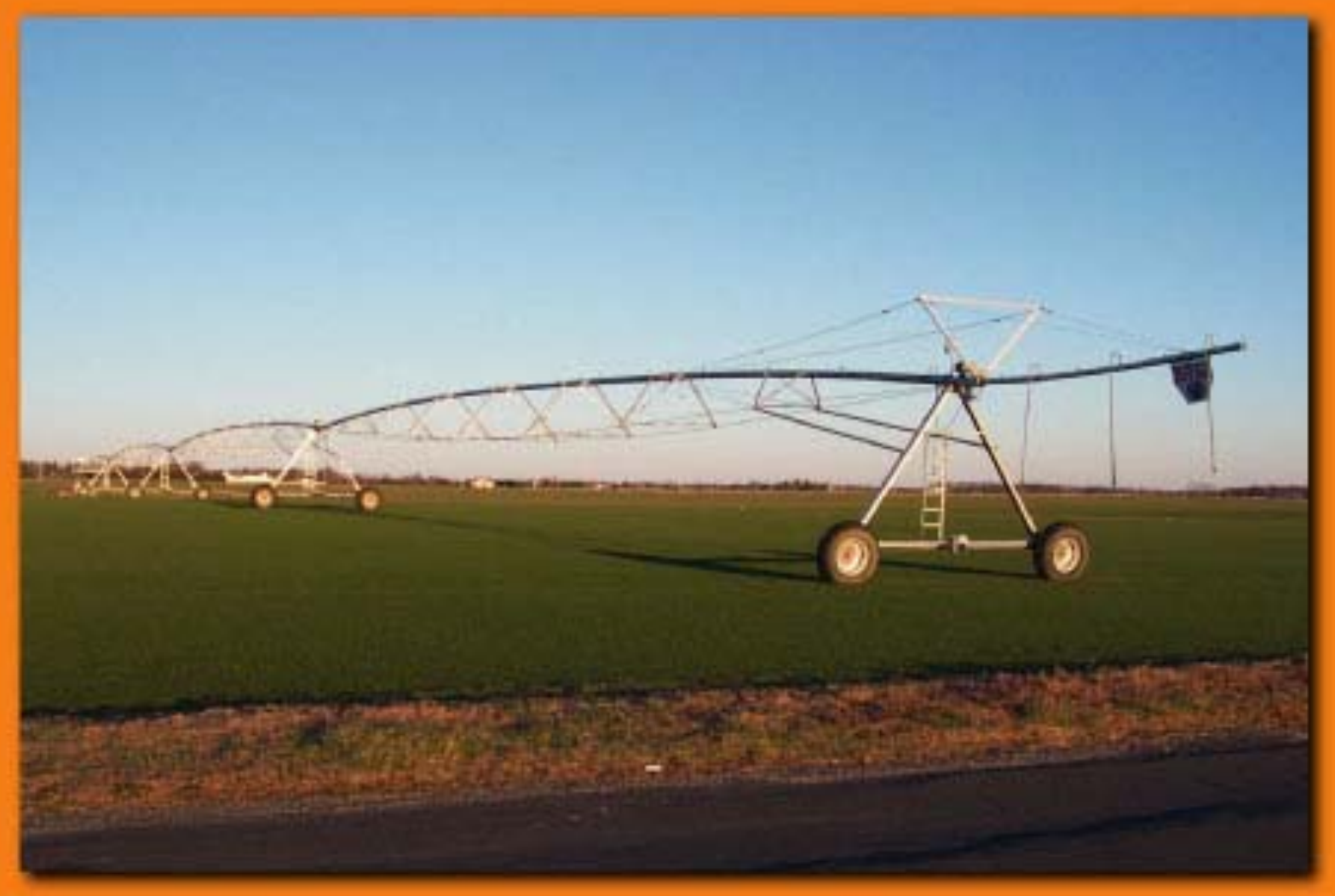

Water-Resources Investigations Report 03-4184

U.S. Department of the Interior U.S. Geological Survey 
This page has been left blank intentionally. 


\section{Simulated Effects of Pumping and Drought on Ground-Water Levels and the Freshwater-Saltwater Interface on the North Fork, Long Island, New York}

By Paul E. Misut, Christopher E. Schubert, Richard G. Bova, and Steven R. Colabufo 


\title{
U.S. Department of the Interior \\ Gale A. Norton, Secretary \\ U.S. Geological Survey \\ Charles G. Groat, Director
}

\author{
U.S. Geological Survey, Reston, Virginia: 2004 \\ For additional information about this report write to: \\ U.S. Geological Survey \\ 2045 Route 112, Bldg. 4 \\ Coram, NY 11727 \\ Email: askny@usgs.gov \\ World Wide Web: http://ny.usgs.gov/ \\ For sale by U.S. Geological Survey, Information Services \\ Box 25286, Denver Federal Center \\ Denver, CO 80225 \\ For more information about the USGS and its products: \\ Telephone: 1-888-ASK-USGS \\ World Wide Web: http://www.usgs.gov/
}

\footnotetext{
Any use of trade, product, or firm names in this publication is for descriptive purposes only and does not imply endorsement by the U.S. Government.

Although this report is in the public domain, permission must be secured from the individual copyright owners to reproduce any copyrighted materials contained within this report.
} 


\section{Contents}

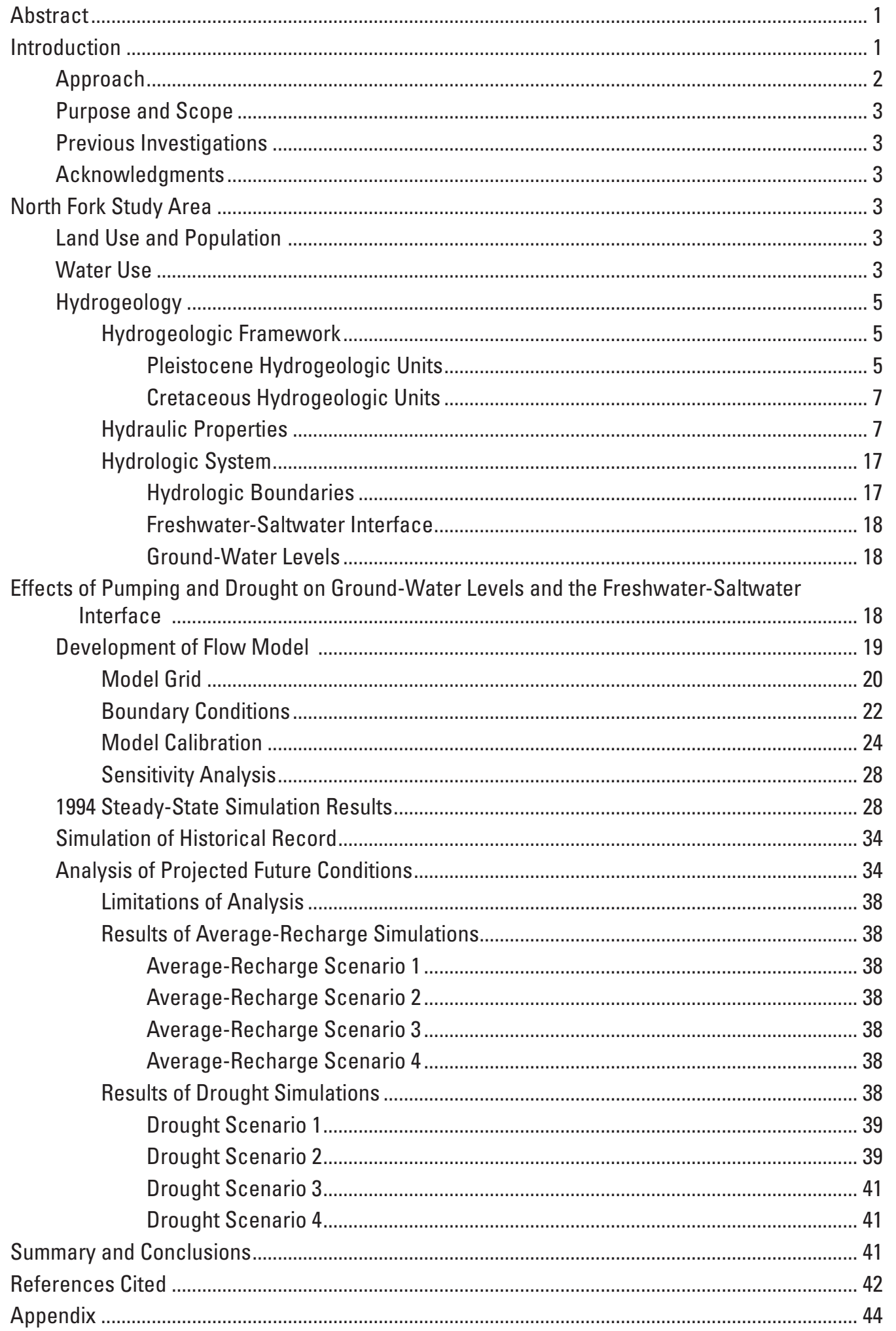




\section{Figures}

1. Location of study area on North Fork, Suffolk County, N.Y. and selected features in the study area.

2. Past and projected public water-supply areas on North Fork, Suffolk County, N.Y.:

A. Village of Greenport and North Fork water supply districts in 1957. B. Riverhead and Suffolk County Water Authority supply districts in 1994. C. Riverhead and Suffolk County Water Authority supply districts in 1998. D. Projected Riverhead and Suffolk County Water Authority supply districts in 2010. E. Projected Riverhead and Suffolk County Water Authority supply districts in 2020.

3. Past and projected public-supply wellfields on North Fork, Suffolk County, N.Y.: A. Publicsupply wellfield locations in 1957. B. Public-supply wellfield locations in 1994. C. Publicsupply wellfield locations in 1998. D. Projected public-supply wellfield locations in 2010. E. Projected public-supply wellfield locations in 2020 ......

4. Sewage-treatment district of the Village of Greenport on the North Fork, Suffolk County, N.Y.

5. Sections A-A' and B-B' showing hydrogeologic units in the North Fork study area ................ 10

6. Surficial distribution of moraine, outwash, and drift on the North Fork, Suffolk County, N.Y.

7. Lower surface altitude and thickness of the upper glacial aquifer zone A on North Fork, Suffolk County, N.Y.: A. Lower surface altitude. B. Thickness

8. Lower surface altitude and thickness of the upper confining unit on North Fork, Suffolk County, N.Y.: A. Lower surface altitude. B. Thickness

9. Lower surface altitude and thickness of the upper glacial aquifer zone B on North Fork, Suffolk County, N.Y.: A. Lower surface altitude. B. Thickness

10. Lower surface altitude and thickness of the lower confining unit on North Fork, Suffolk County, N.Y.: A. Lower surface altitude. B. Thickness

11. Lower surface altitude and thickness of the upper glacial aquifer zone $C$ on North Fork, Suffolk County, N.Y.: A. Lower surface elevation. B. Thickness

12. Upper and lower surface altitude and thickness of the Magothy aquifer on North Fork, Suffolk County, N.Y.: A. Upper surface elevation. B. Lower surface elevation.

13. Vertical leakance values for the Pleistocene upper and lower confining units on the North Fork, Suffolk County, N.Y.: A. Upper confining unit. B. Lower confining unit ..

14. Location of local freshwater flow systems on North Fork, Suffolk County, N.Y. ....................... 17

15. Water-table altitude in March-April 1994 on North Fork, Suffolk County, N.Y. ....................... 19

16. Schematic representation of the freshwater-saltwater interface along model row i,

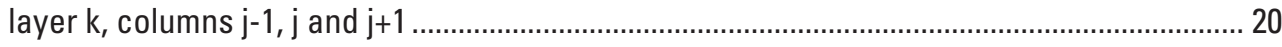

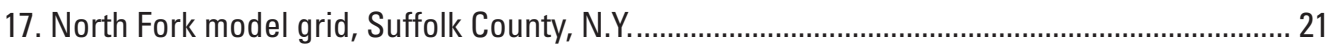

18. Sea floor bathymetry near North Fork, Suffolk County, N.Y. .................................................. 21

19. Conceptual diagram showing boundary conditions of the North Fork Model, Suffolk County, N.Y.

20. Locations of recharge zones, public water-supply districts, freshwater bodies, and recharge rates used for 1994 steady-state simulations in North Fork model, Suffolk County, N.Y.: A. Recharge zones and locations of freshwater bodies. B. Public watersupply districts. C. Ground-water-recharge rates. 
21. Locations of public-supply and commercial-supply wells in 1994 in North Fork model, Suffolk County, N.Y.: A. Public- and commercial-supply wells screened less than 45 feet below sea level. B. Public- and commercial-supply wells screened 45 feet or more below sea level. C. Agricultural parcels and irrigation wells

22. Locations of observation wells used in calibration of North Fork model, Suffolk County, N.Y.: A. Wells used for water-level measurement. B. Wells used for freshwater-

saltwater interface measurement. C. Secondary wells near western extent of grid 26

23. Measured and simulated ground-water level and freshwater-saltwater interface depths: A. Measured and simulated water levels at well S16764. B. Simulated head and interface depth at well S4091

24. Sensitivity of simulated hydraulic head to variations in the values of selected parameters in the North Fork model: A. Mean residual. B. Root mean square error...

25. Simulated water-level and freshwater-saltwater interface position for the upper glacial aquifer zone A, 1994 average annual conditions on the North Fork, Suffolk County, N.Y.: A. Simulated 1994 water levels in freshwater-flow system. B. Simulated 1994 freshwatersaltwater interface position

26. Simulated water-level and position of freshwater-saltwater interface position for the upper glacial aquifer zone B, 1994 average annual conditions on North Fork, Suffolk County, N.Y.: A. Simulated 1994 water levels in freshwater-flow system. B. Simulated 1994 freshwater-saltwater interface position. C. Simulated 1994 vertical gradient between upper glacial aquifer zones $A$ and $B$

27. Simulated water level and freshwater-saltwater interface for the upper glacial aquifer zone C,1994 average annual conditions on North Fork, Suffolk County, N.Y.: A. Simulated 1994 water levels in freshwater-flow system. B. Simulated 1994 freshwater-saltwater interface position. C. Simulated 1994 vertical gradient between upper glacial aquifer zones $B$ and $C$

28. Simulated water level and position of freshwater-saltwater interface for the Magothy aquifer, 1994 average annual conditions on North Fork, Suffolk County, N.Y.: A. Simulated 1994 water levels in freshwater-flow system. B. Simulated 1994 freshwater-saltwater interface position. C. Simulated 1994 vertical gradient between upper glacial aquifer zone $\mathrm{C}$ and Magothy layer.

29. Vertical sections showing simulated position of freshwater-saltwater interface under 1994 average annual conditions in North Fork model, Suffolk County, N.Y.

30. Vertical sections showing model-generated heads and freshwater-saltwater interface positions at selected wells in scenarios 1 through 4 under simulated average-recharge conditions in North Fork model, Suffolk County, N.Y.: A. Scenario 1: Well S105669 (redeveloped as S108347). B. Scenario 2: Well S15795

\section{Tables}

1. Geologic and hydrogeologic units in the North Fork study area of eastern Long Island, N.Y.

2. Hydraulic conductivity of Pleistocene and uppermost Cretaceous hydrogeologic units for North Fork model.

3. Discharge of Moores Drain at Route 25 in Greenport, Suffolk County, N.Y., on four sampling dates in 1998-99 
4. Simulated 1994 ground-water-recharge rates for North Fork model, Suffolk County, N.Y .... 24

5. Measured (March-April 1994) and simulated water levels and hydraulic gradients at six well pairs in North Fork study area, Suffolk County, N.Y.

6. Calibration statistics on ground-water levels and saltwater interface for hydrogeologic units in North Fork model....................................................................................................... 28

7. Parameter values used in North Fork model ............................................................................. 28

8. Model-generated fresh-ground-water budget for 1994 average annual conditions .............. 31

9. Monthly distribution of recharge and discharge in North Fork model ...................................... 37

10. Data used for the five stress periods of the 65-year (1941-2005) simulation in North

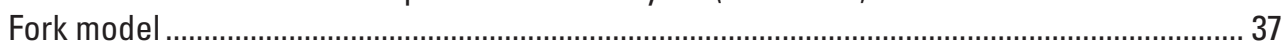

11. Summary of water-supply scenarios for years 2006-20 in North Fork model .......................... 37

\section{CONVERSION FACTORS, ABBREVIATIONS , AND VERTICAL DATUM}

\begin{tabular}{lcl}
\hline Multiply & By & To Obtain \\
\hline feet $(\mathrm{ft})$ & 0.3048 & meter \\
feet per day $(\mathrm{ft} / \mathrm{d})$ & 0.3048 & meter per day \\
gallon per minute $(\mathrm{gal} / \mathrm{min})$ & 0.002228 & cubic feet per second \\
square mile $\left(\mathrm{mi}^{2}\right)$ & 2.590 & square kilometer \\
acres & 5360 & square feet \\
inches per year $(\mathrm{in} / \mathrm{yr})$ & 2.54 & centimeters per year \\
million gallons per day $(\mathrm{Mgal} / \mathrm{d})$ & 0.04381 & cubic meter per second \\
gallon $(\mathrm{gal})$ & 3.785 & liter \\
cubic feet per second $(\mathrm{ft} / \mathrm{s})$ & 448.83 & gallons per minute \\
pound per cubic feet $\left(\mathrm{lb} / \mathrm{ft}^{3}\right)$ & 16.018 & kilograms per cubic meter \\
pound per second per foot $(\mathrm{lb} / \mathrm{s} / \mathrm{ft})$ & 14.88195 & kilogram per second per meter \\
\hline
\end{tabular}

Other abbreviations used in this report:

milligrams per liter $(\mathrm{mg} / \mathrm{L})$

microsiemens per centimeter at $25^{\circ}$ Celsius $\quad(\mu \mathrm{S} / \mathrm{cm})$

In this report, the term "sea level" is used to refer to the local coastal mean sea-level datum and is not used as a substitute for the National Geodetic Vertical Datum of 1929 or the North American Vertical Datum of 1988. 


\title{
Simulated Effects of Pumping and Drought on Ground- Water Levels and the Freshwater-Saltwater Interface on the North Fork of Long Island, New York
}

\author{
By Paul E. Misut' ${ }^{1}$ Christopher E. Schubert' ${ }^{1}$, Richard G. Bova ${ }^{2}$, and Steven R. Colabufo ${ }^{2}$
}

\begin{abstract}
Ground water is the sole source of freshwater on the North Fork of Long Island. Future demands for the limited freshwater supply during a prolonged drought could cause drawdowns that induce saltwater intrusion and render the supply unusable. The freshwater system on the North Fork contains several localized, hydraulically isolated aquifers bounded by salty water. The need for information on the ability of these aquifers to meet future demands prompted a 4year study to develop a ground-water flow model to simulate several proposed pumping scenarios under long-term average conditions and during a hypothetical drought, and to delineate the resulting ground-water levels and movement of the freshwater-saltwater interface. The model code selected was SHARP, a quasi-three-dimensional finite-difference method of simulating freshwater and saltwater flow simultaneously.

Two sets of four proposed pumping scenarios were evaluated. The first represented average recharge from precipitation during 2006-20; the second represented the same period and conditions except for a 5-year period of drought conditions. The average-recharge simulations used the long-term (1959-99) rate of recharge; the drought simulations applied a 20-percent reduction in recharge rate and a 20-percent increase in the 1999 rate of agricultural pumpage during 2011-15.

The simulated movement of the freshwater-saltwater interface in future withdrawal and recharge scenarios indicates that the interface may rise beneath pumped wells at Inlet Drive, Brecknock Hall, Main Bayview Road, Islands End, North Road, and Alvah's Lane. Either (1) movement of the interface to within 50 feet of the well screen, (2) a large percent change in the distance between the interface and the well screen, or (3) movement of the interface through a clay layer is a cause for concern. Wellfields in which saltwater intrusion does not appear to be a cause for concern were those at Ackerly Pond, Kenney's Road, Middle Road, Rocky Point

U.S. Geological Survey, Coram, N.Y.

${ }^{2}$ Suffolk County Water Authority, Great River, N.Y.
\end{abstract}

Road, and hypothetical sites where future wellfields have been proposed.

\section{Introduction}

Ground water is the sole source of drinking water and irrigation supply on the North Fork of eastern Long Island (fig. 1), where the freshwater system consists of a sequence of sand and gravel aquifers that are mostly bounded by saltwater. Nearly all drinking water and irrigation water is withdrawn from the surficial (Pleistocene) aquifers; the deeper aquifers contain mostly saline water and are not used for water supply or irrigation.

Previous studies by the U.S. Geological Survey (USGS) and other agencies have documented the susceptibility of the North Fork aquifers to saltwater intrusion and upconing at water-supply wells in response to heavy pumping. Early water-resources investigations (Hoffman, 1961; Crandell, 1963 ) reported steady increases in ground-water pumping starting about 1950 , followed by saltwater intrusion during subsequent years. In addition, a growing body of evidence indicates extensive pesticide contamination of monitoring wells and private water-supply wells near agricultural areas throughout eastern Long Island (Baier and Moran, 1981; Baier and Robbins, 1982a and 1982b; Soren and Steltz, 1984; BohnBuxton and others, 1996); this contamination further limits the finite freshwater supply.

Concerns have been raised recently over the ability of public water-supply systems on the North Fork to meet current and future demands for drinking water and irrigation water in summer, when the population doubles. This increased summer demand in a prolonged drought could result in drawdowns that induce saltwater intrusion and potential abandonment of affected wells. These concerns, in addition to reported contamination of supply wells by domestic wastewater (E.J. Rosavitch, Suffolk County Water Authority, oral commun., 1997) and the potential for migration of contaminants from a local landfill, have prompted efforts to plan for the maintenance, upgrading, and expansion of present public water-supply systems and to protect the remaining 

North Fork of Long Island, New York

\section{A. Location of study area}

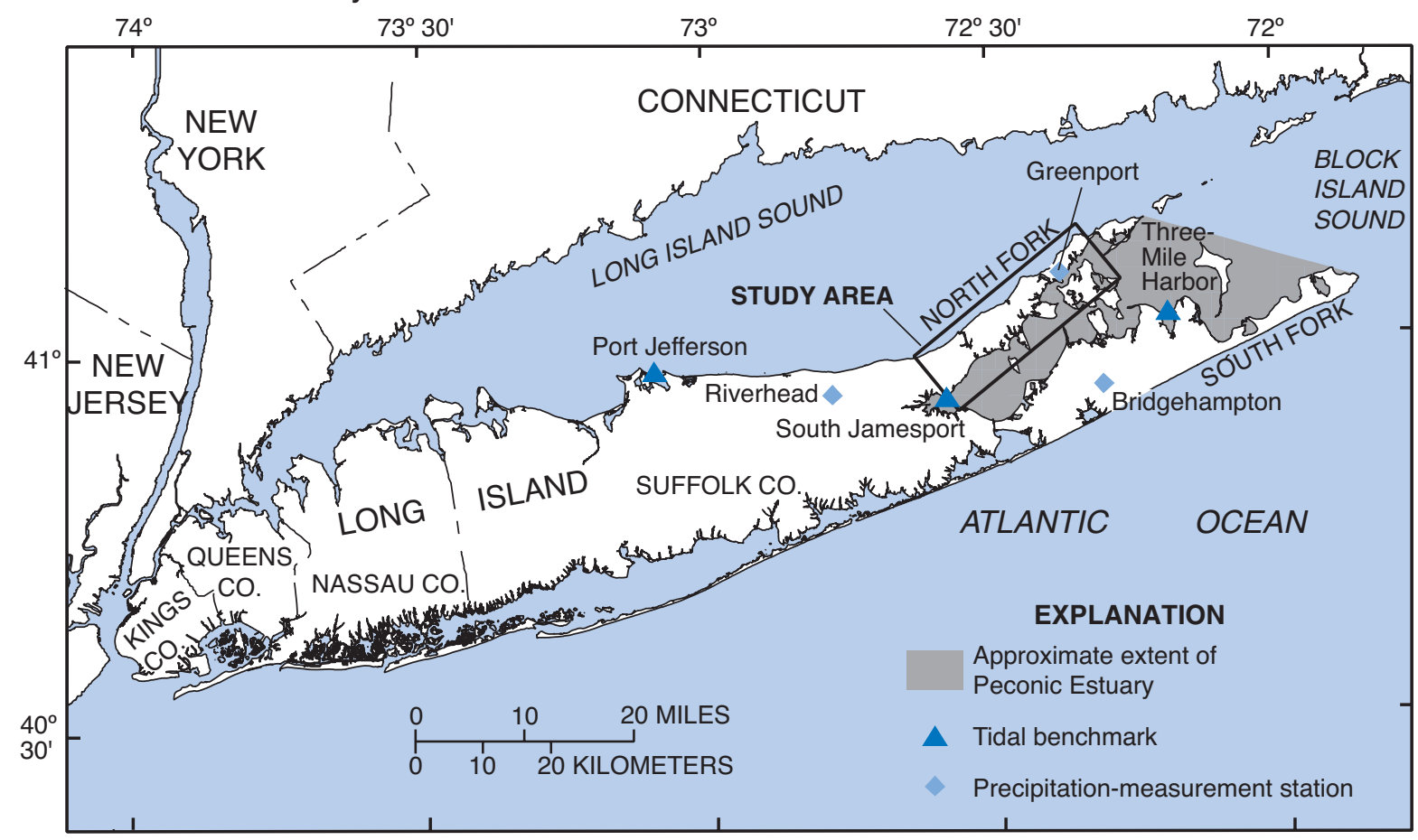

Base from U.S. Geological Survey digital data, 1:24,000,

Universal Transverse Mercator projection, NAD27, Zone 18

\section{B. Selected features in the study area}

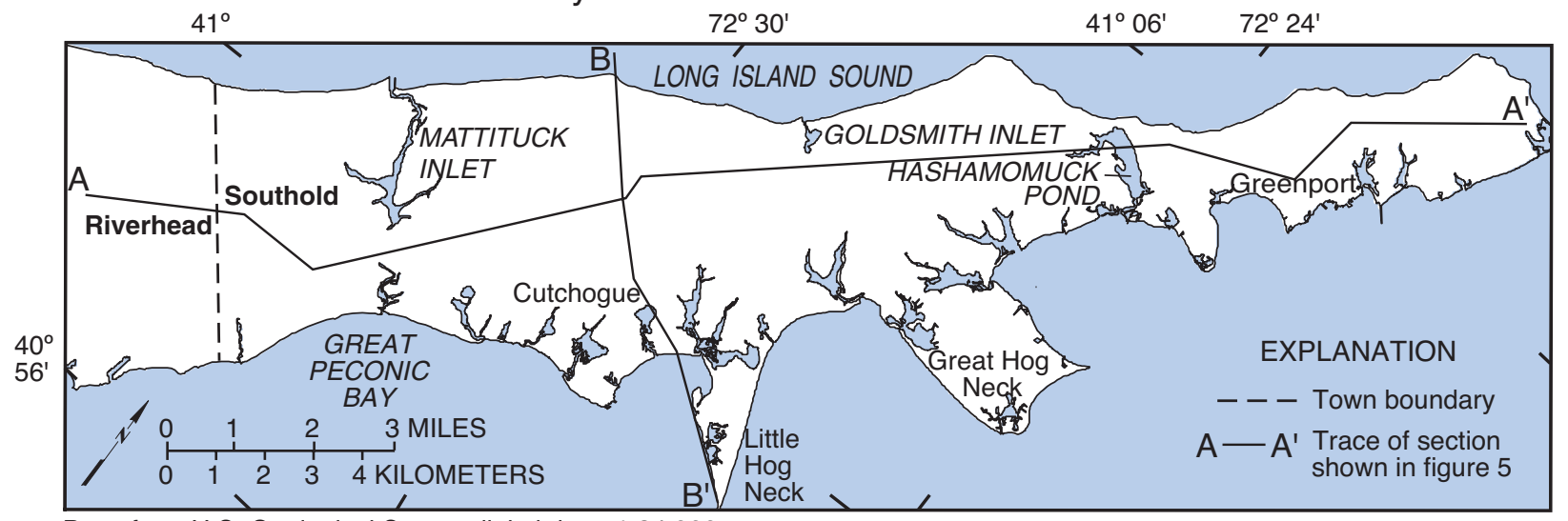

Base from U.S. Geological Survey digital data, 1:24,000,

Universal Transverse Mercator projection, NAD27, Zone 18

Figure 1. Location of study area on North Fork, Suffolk County, N.Y. and selected features in the study area.

potable ground-water supplies. Such planning will require the development of water-supply strategies that account for the effects of present and future withdrawals and drought on ground-water levels and the position of the freshwatersaltwater interface.

\section{Approach}

The need for information on aquifer capacity to meet projected demands prompted the USGS, in cooperation with the Suffolk County Water Authority (SCWA), to begin a 4-year study in 1996 to analyze the effects of pumping and drought on ground-water levels and the position of freshwatersaltwater interface. This effort entailed (1) development of a model of freshwater and saltwater flow to simulate a wide range of hypothetical pumping scenarios through the year 2020, and (2) evaluation of the model-generated water levels and interface response within the individual aquifers. Two sets of four scenarios were evaluated: the first set represented a wide range of public-supply, agricultural, and miscellaneous pumping rates under normal (average long-term) rates of recharge from precipitation; the second set represented the same conditions with the addition of a 5-year drought during the years 2011-2015, represented by a 20-percent decrease in 
recharge rate and a corresponding increase in the agricultural irrigation requirement to offset the diminished precipitation. The resulting simulated changes in ground-water levels and interface altitude were tabulated and evaluated.

\section{Purpose and Scope}

This report (1) describes the geologic framework and the hydrologic boundaries of the aquifer system, (2) describes the development and calibration of transient-state and steadystate three-dimensional ground-water-flow simulations, (3) depicts in maps and vertical sections the present and predicted future ground-water levels, freshwater-saltwater interface position, and directions of ground-water flow, and (4) depicts the effects of simulated pumping rates under normal-recharge and drought conditions on water levels and the interface, as indicated by the two sets of water-use scenarios. Tables of precipitation, recharge, and pumpage data are given in appendixes at the end of the report.

\section{Previous Investigations}

The first islandwide descriptions of the geology and ground-water conditions of Long Island were given by Fuller (1914) and Veatch and others (1906), respectively. A more recent comprehensive account of Long Island hydrology is given by Cohen and others (1968). The history of groundwater development on Long Island is summarized in Nemickas and others (1989). The first digital ground-water models of the North Fork were developed and described by Bohn-Buxton and others (1996). Ground-water contributingarea boundaries on the North Fork were delineated by Schubert (1998), who also defined ground-water flow paths and traveltimes (Schubert, 1999). A model of the freshwatersaltwater interface in the Brooklyn-Queens aquifer system was constructed by Kontis (1999), and models of the freshwatersaltwater interface on Cape Cod, Martha's Vineyard, and Nantucket, Mass., were constructed by Masterson and Barlow (1997). The freshwater-saltwater interface in the Coastal Plain aquifer system of New Jersey was evaluated by Spitz (1998) and Pope and Gordon (1999). The interface in the coastal aquifer system of Virginia was studied by Richardson (1994). A bibliography on the occurrence of saltwater intrusion in aquifers along the Atlantic Coast is given by Barlow and Wild (2002).

\section{Acknowledgments}

Thanks are extended to Edward Rosavitch and Joseph Pokorny, former and current Chief Engineers of the SCWA, respectively, for their technical support and cooperation during the investigation. Appreciation also is expressed to Jeff Altorfer and Tyrand Fuller of the SCWA Engineering
Department for providing information and assisting with data collection.

\section{North Fork Study Area}

The North Fork is bordered by Long Island Sound on the north and by embayments of the Peconic Estuary on the south (fig. 1). Local tidal benchmarks are at Port Jefferson, Threemile Harbor, and South Jamesport; precipitation stations are at Riverhead, Greenport, and Bridgehampton (fig. 1). The modeled study area encompasses about $100 \mathrm{mi}^{2}$ in the Town of Southold and the eastern part of the Town of Riverhead (fig. 1). The highest elevation is about $160 \mathrm{ft}$ above sea level, west of Mattituck Inlet (fig. 1); the lowest bathymetric elevation is about $100 \mathrm{ft}$ below sea level, north of Greenport (fig. 1).

\section{Land Use and Population}

About 50 percent of the study area is used for agricultural purposes that include truck farming, sod farming, and viniculture (Suffolk County Department of Planning Department, 2001). About 25 percent has residences, although some of the residences are unoccupied during the winter. Proposed development of the vacant residential land could result in the creation of about 9,230 new dwelling units. In 1990, the Town of Southold contained 12,979 dwelling units; thus, maximum development could result in a total of about 22,200 dwelling units. This represents a 71-percent increase from the 1990 level. About 3 percent of the land available for development is zoned commercial and (or) industrial.

The combined year-round and seasonal population of the Town of Southold in 1990 was about 36,000 and is expected to increase by about 72 percent at maximum development around the year 2020 (Suffolk County Department of Planning, 2001). The year-round population in 1990 was about 56 percent of the total and is expected to increase only slightly--to 57 percent of the total--by 2020, which is about a 75 -percent increase in the year-round population. The vacation season runs from about Memorial Day (the end of May) to Labor Day (the beginning of September).

\section{Water Use}

Communities on the North Fork were served in 2002 by the SCWA and Riverhead Water District. Past and projected service areas $(1957,1994,1998,2010$, and 2020) are depicted in figures 2A-E. The service-area locations for the Riverhead Water District are based on geographic information system (GIS) coverages (Dennis Jackson, Suffolk County Department of Health Services, written commun., 1995). The locations of public-supply wells operated prior to 1958 were digitized and used to estimate the service-area location for the former 


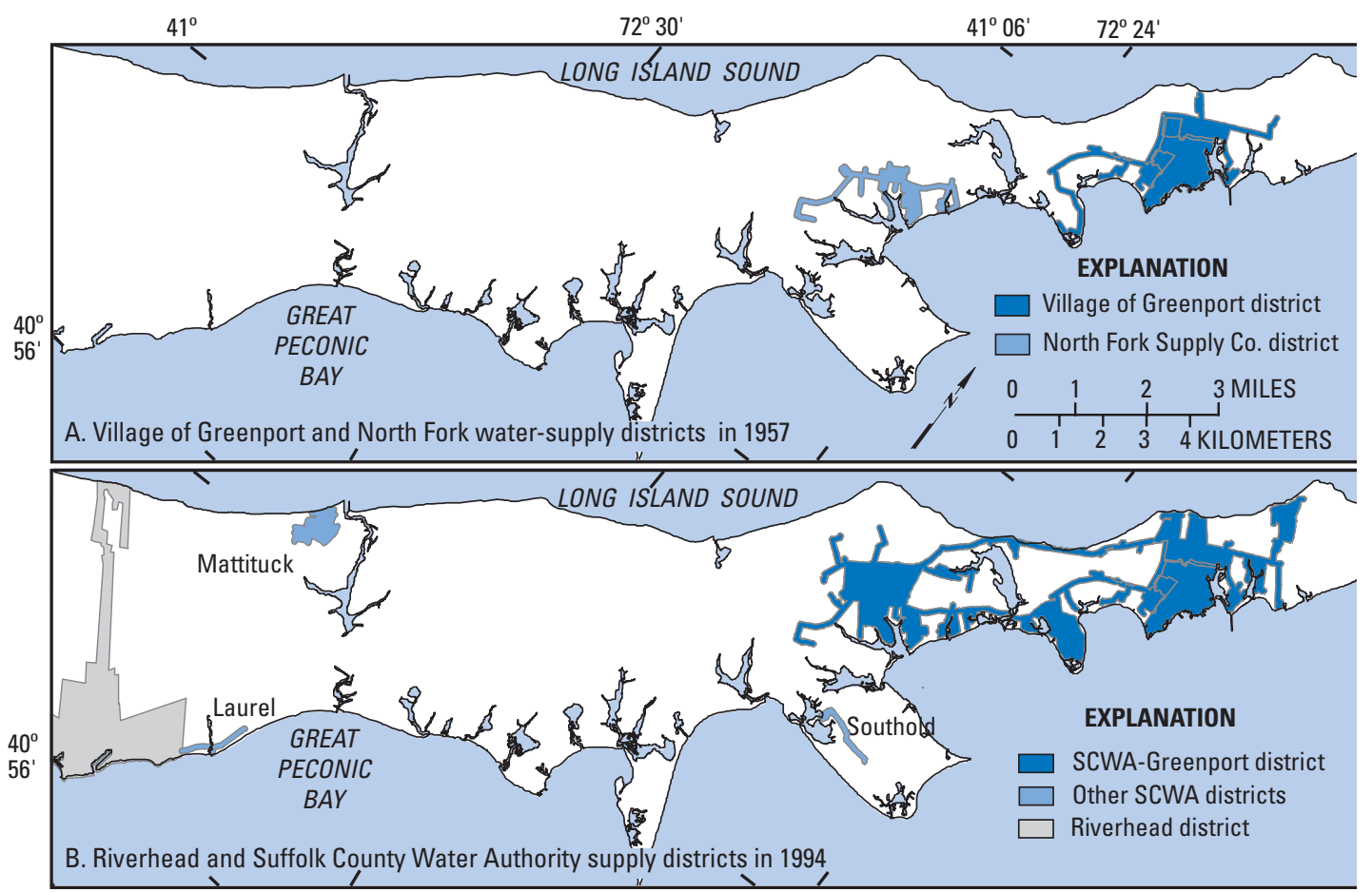

Figure 2. Past and projected public water-supply areas on North Fork, Suffolk County, N.Y.: A. Village of Greenport and North Fork water supply districts in 1957. B. Riverhead and Suffolk County Water Authority supply districts in 1994. C. Riverhead and Suffolk County Water Authority supply districts in 1998. D. Projected Riverhead and Suffolk County Water Authority supply districts in 2010. E. Projected Riverhead and Suffolk County Water Authority supply districts in 2020. (Location is shown in fig. 1)
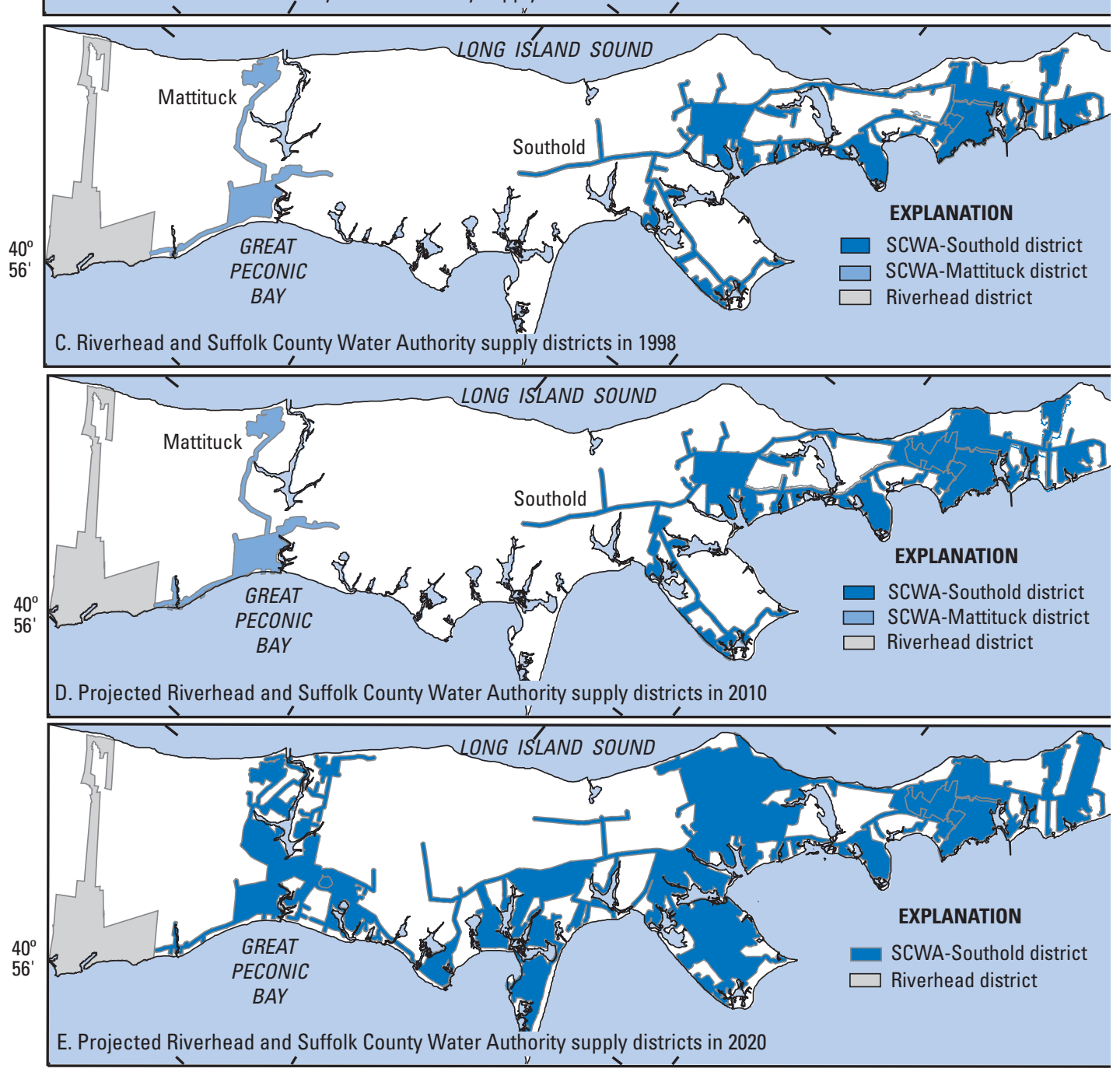

Base from U.S. Geological Survey digital data, 1:24,000,

Universal Transverse Mercator projection, NAD27, Zone 18 
North Fork Water Company and Village of Greenport Water Supply; the service-area locations for the former Greenport Water District were digitized by Schubert (1998) from a 1992 map of current and proposed facilities (Roy F. Weston, Inc., 1992). The service-area locations for the SCWA in 1994 were digitized by Schubert (1998) from the SCWA's 1995 distribution-system maps (Jeff Altorfer, Suffolk County Water Authority, written commun., 1996); the remaining service-area locations were assembled by the SCWA (Jeff Altorfer, written commun., 1999).

Locations of public-supply wellfields in 1957, 1994, and 1998, and of projected future public-supply systems in 2010 and 2020, are shown in figures 3A-E. The wellfield locations for the former Greenport Water District were digitized by Schubert (1998) from a 1992 map of current and proposed facilities (Roy F. Weston, Inc., 1992). Wellfield locations for the SCWA in 1994 were digitized by Schubert (1998) from the SCWA's 1995 distribution-system maps (Jeff Altorfer, written commun., 1996); the wellfield locations in 1998 were assembled by the SCWA (Jeff Altorfer, written commun., 1999).

Annual public-supply pumpage for 1957,1994 , and 1998 are summarized in appendixes 1,2, and 3, respectively; miscellaneous pumpage for 1993-95 is summarized in appendix 4. Estimated past and projected (2020) pumpage values are as follows:

\begin{tabular}{lcccr}
\hline & \multicolumn{4}{c}{ Pumpage, in million gallons per day } \\
\cline { 2 - 5 } \multicolumn{1}{c}{ Category } & $\mathbf{1 9 5 7}$ & $\mathbf{1 9 9 4}$ & $\mathbf{1 9 9 8}$ & \multicolumn{1}{c}{$\mathbf{2 0 2 0}$} \\
\hline Public supply & 0.5 & 1.1 & 1.1 & $2.0-4.0$ \\
Miscellaneous pumpage & 0.1 & 0.2 & 0.2 & 0.2 \\
\hline
\end{tabular}

Monthly 1994 pumpage for each wellfield associated with the Greenport and Riverhead Water Districts and SCWA was compiled by Schubert (1998) from data provided by T.A. Nanos of the Suffolk County Department of Health Services (written commun., 1995, 1996) and by Paul Kuzman of the Suffolk County Water Authority (written commun., 1995). SCWA pumpage in 1998 by each wellfield was also was compiled by Paul Kuzman (written commun., 1999).

Most public-supply water is returned to the water table, mainly through septic systems but also, to a lesser extent, as leakage from the water-distribution system; the rest is not returned and is lost from the ground-water system. The amount of public-supply water that reaches the water table in unsewered areas of other parts of Long Island has been estimated to be about 85 percent of total public-supply pumpage (Franke and McClymonds, 1972). Communities on the North Fork and elsewhere in eastern Suffolk County that obtain drinking water from local water-supply systems or private wells generally return most of this water to the ground-water system at nearly the same location from which it is withdrawn (Schubert, 1998); therefore, the withdrawal and return flow of local- or private-supply water was not considered in this investigation. All water pumped for public supply and distributed in the sewage-treatment district of the Village of Greenport (fig. 4), which discharges treated wastewater to Long Island Sound, is considered to be removed from the ground-water system.

Irrigation water in the study area is pumped from shallow wells. A method for estimating the total agricultural irrigation requirement, in inches per year, was described and applied to 1994 conditions by Schubert (1998). Estimated past and projected irrigation requirements calculated by this method are as follows: 1941-61 and 1967-70: $7.0 \mathrm{in} / \mathrm{yr}$; 1962-66 drought: $10.4 \mathrm{in} / \mathrm{yr}$; and 1971-2020 (1999 conditions): $3 \mathrm{in} / \mathrm{yr}$. The irrigation requirement during a future projected drought is estimated to total $5.3 \mathrm{in} / \mathrm{yr}$.

\section{Hydrogeology}

The hydrogeology of the North Fork was evaluated from published information and from exploratory drilling of five deep (about $400 \mathrm{ft}$ ) wells during this study. The hydraulic properties of hydrogeologic units were compiled from previous investigations of unconsolidated deposits on Long Island and in similar settings in the Atlantic Coastal Plain of New Jersey and on western Cape Cod, Massachusetts. Detailed information on the hydrogeologic framework of the North Fork is given in a companion report (Schubert and others, 2003).

\section{Hydrogeologic Framework}

The framework of the North Fork consists of a series of Pleistocene and Cretaceous aquifers and confining units that overlie southeastward-sloping Paleozoic and Precambrian bedrock (Schubert and others, 2003). Descriptions of the geologic and hydrogeologic units are given in table 1 . The generalized hydrogeologic framework along southwestnortheast $\left(\mathrm{A}^{-} \mathrm{A}^{\prime}\right)$ and northwest-southeast $\left(\mathrm{B}-\mathrm{B}^{\prime}\right)$ sections is depicted in figure 5 (location of section traces shown in fig. 1). The focus of this investigation was the fresh ground-water flow system in the Pleistocene and uppermost Cretaceous units. The deeper Cretaceous units contain saline water.

\section{Pleistocene Hydrogeologic Units}

On Long Island, saturated coarse-grained deposits of Pleistocene age commonly are referred to as the upper glacial aquifer. In this report, following the work of Schubert and others (2003), the upper glacial aquifer has been divided into three zones (table 1). In general, zone $\mathrm{A}$ is the upper glacial aquifer above the upper confining unit; zone $\mathrm{B}$ is the upper glacial aquifer between the upper and lower confining units; and zone $\mathrm{C}$ is the upper glacial aquifer below the lower confining unit.

Upper glacial aquifer zone A, which is unconfined, is further divided based on the surficial distribution of the Roanoke Point outwash and moraine and Ronkonkoma drift 


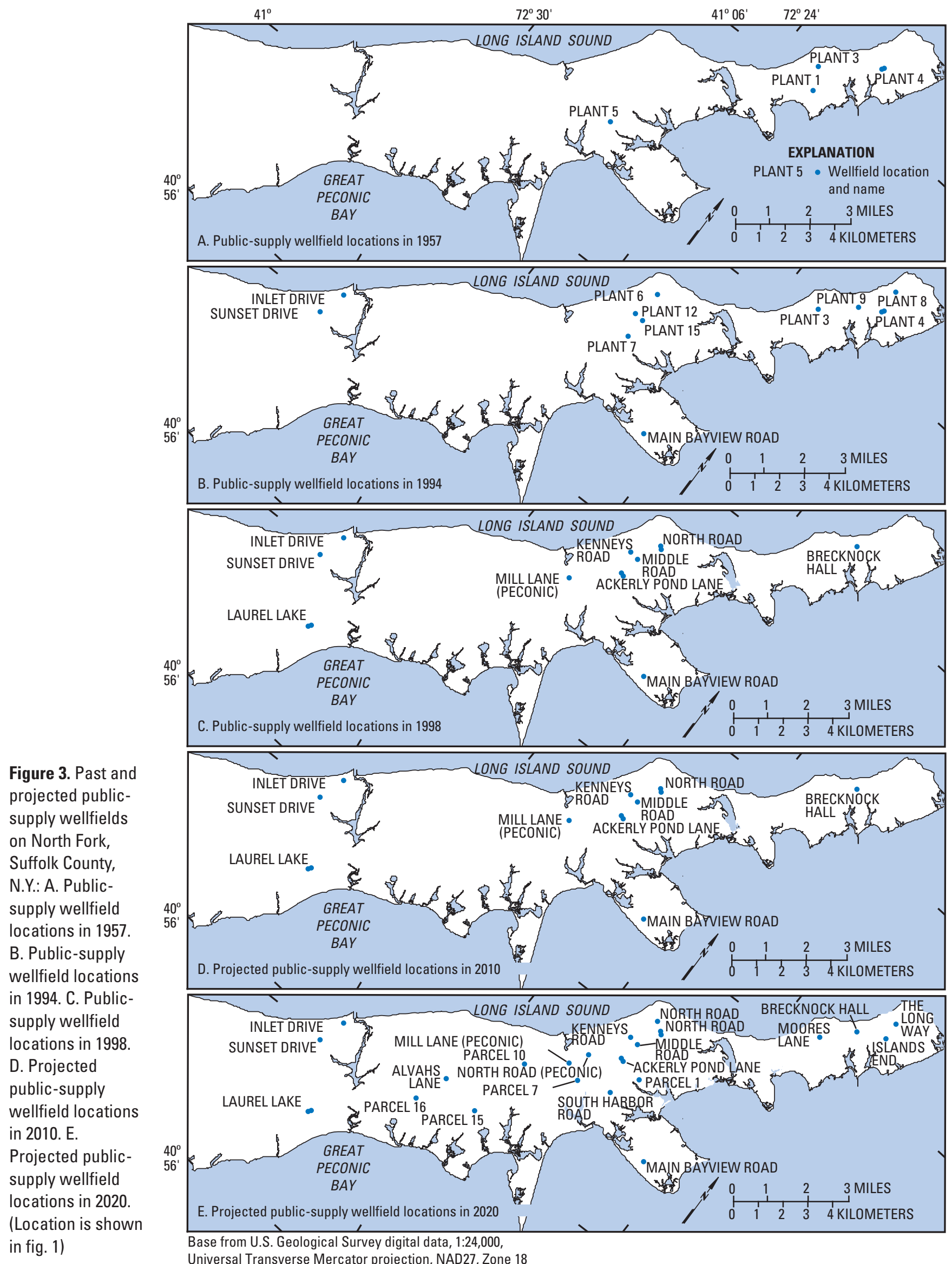




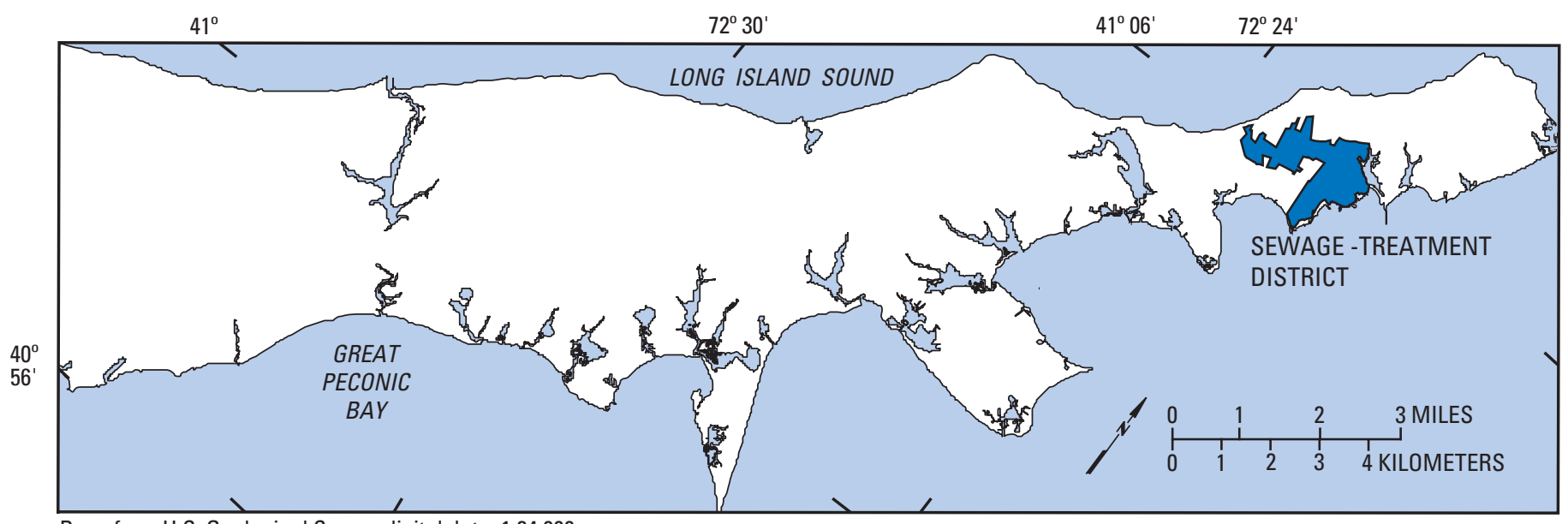

Base from U.S. Geological Survey digital data, 1:24,000,

Universal Transverse Mercator projection, NAD27, Zone 18

Figure 4. Sewage-treatment district of the Village of Greenport on the North Fork, Suffolk County, N.Y. (Location is shown in fig. 1)

(fig. 6). In the northernmost part of the study area, zone A consists of moraine deposits, and in the central part it consists of outwash. In the south where the drift is at the surface, zone A consists of the upper part of the drift. The outwash deposits are moderately to well-sorted sand, gravel, and silt; the moraine deposits are poorly to moderately sorted silt, sand, and gravel; and the drift deposits are poorly to well-sorted sand, gravel, and silt. The upper confining unit is glacial-lake clay with silt and fine sand. The lower-surface altitude and thickness of the upper glacial aquifer zone $\mathrm{A}$ are depicted in figures 7A-B. The lower-surface altitude and thickness of the upper confining unit are depicted in figures 8A-B.

Upper glacial aquifer zone B includes the Ronkonkoma drift where it is confined below the upper glacial-lake clay. Unconfined parts of zone B include the drift present below the outwash and moraine where the glacial-lake clay is absent, and the lower part of the drift where it is at the surface in the southern part of the study area. Below zone B is the lower confining unit, which is marine and nonmarine clay with lenses of sand and gravel in the southern part of the study area, and, elsewhere, glacial-lake clay and silt. The lower-surface altitude and thickness of the upper glacial aquifer zone B are depicted in figures 9A-B. The lower-surface altitude and thickness of the upper confining unit are depicted in figures 10A-B.

Upper glacial aquifer zone $\mathrm{C}$ includes poorly to wellsorted sand and gravel associated with the Montauk till, and post-Cretaceous (?) deposits confined below marine, nonmarine, and (or) glacial-lake clay. Below zone $\mathrm{C}$ is the Magothy aquifer of Cretaceous age. The lower-surface altitude and thickness of the upper glacial aquifer zone $\mathrm{C}$ are depicted in figures 11A-B.

\section{Cretaceous Hydrogeologic Units}

The Cretaceous hydrogeologic units in descending order include the Magothy aquifer, Raritan confining unit, and Lloyd aquifer. The Magothy aquifer includes the deposits of the Magothy Formation-Matawan Group, undifferentiated, which consist of sand with silt, clay, and lignite and, in the basal 100-200 ft, gravel (Jensen and Soren, 1974). The lowerand upper-surface altitudes and thickness of the Magothy aquifer are depicted in figures 12A-B. Below the Magothy aquifer is the Raritan confining unit, which consists of clay and silt deposits of the unnamed clay member of the Raritan Formation. The deepest Cretaceous unit is the Lloyd aquifer, which consists of sand and gravel of the Lloyd Sand Member of the Raritan Formation.

\section{Hydraulic Properties}

Horizontal and vertical hydraulic conductivity values of aquifers and confining units were compiled from previous studies on Long Island and Cape Cod and are summarized in table 2. The depositional environment and lithology of western Cape Cod are comparable to those of glacial deposits on the North Fork (Schubert, 1999). The moraine deposits above the upper confining layer are probably the least homogeneous and, therefore, the least accurately represented by a bulk hydraulic value. Vertical leakance values for the two confined aquifers are shown in figures 13A-B. Vertical leakance between two aquifers separated by a confining unit is calculated as follows (Essaid, oral commun., 2000):

$$
\text { Leakance }(x, y)=\frac{1}{\frac{\left(\frac{b(x, y)_{\text {lower }}}{2}\right)}{K v(x, y)_{\text {lower }}}+\frac{\left(\frac{b(x, y)_{\text {upper }}}{2}\right)}{K v(x, y)_{\text {upper }}}+\frac{b(x, y)_{\text {conf }}}{K v(x, y)_{\text {conf }}}}
$$

where:

Leakance $(x, y)=$ leakance $[1 /$ time $]$ between two aquifers separated by a confining unit

$b(x, y)_{\text {lower }}, b(x, y)_{\text {lower }}, b(x, y)_{\text {conf }}=$ thickness [length] of lower unit, upper unit, and confining unit, respectively. These are functions of horizontal location $\mathrm{x}, \mathrm{y}$. 


\section{Simulated Effects of Pumping and Drought on Ground-Water Levels and the Freshwater-Saltwater Interface on the North Fork of Long Island, New York}

Table 1. Geologic and hydrogeologic units in the North Fork study area of eastern Long Island, N.Y.

[From Schubert and others, 2003. Descriptions of selected Pleistocene deposits adapted from Soren, 1978; Nemickas and Koszalka, 1982; Soren and Stelz, 1984; Prince, 1986; and Schubert, 1999. Descriptions of Cretaceous deposits and bedrock modified from Jensen and Soren, 1974.]

\begin{tabular}{|c|c|c|c|c|}
\hline Age & \multicolumn{2}{|l|}{ Geologic unit } & Hydrogeologic unit & Description \\
\hline \multirow{7}{*}{$\begin{array}{l}\frac{0}{0} \\
\frac{0}{0} \\
\frac{0}{2} \\
\frac{0}{2}\end{array}$} & \multicolumn{2}{|c|}{ Roanoke Point outwash and moraine } & $\begin{array}{l}\text { Upper glacial aquifer } \\
\text { zone } \mathrm{A}\end{array}$ & $\begin{array}{l}\text { Outwash deposits consist of tan, moderately to well-sorted } \\
\text { fine to coarse sand and gravel, locally with light-brown, fine } \\
\text { sand and silt in basal 10-20 feet. Moraine deposits consist of } \\
\text { brown, poorly to moderately sorted, medium to coarse sand } \\
\text { and gravel with some fine sand and silt, and discontinuous, } \\
\text { poorly to unsorted lenses of gray and brown, fine to medium } \\
\text { sand and silt with some clay, coarse sand, and gravel. }\end{array}$ \\
\hline & \multicolumn{2}{|c|}{ Upper glacial-lake clay } & Upper confining unit & $\begin{array}{l}\text { Tan, gray, and brown fine sand, silt, and clay, commonly with } \\
\text { abundant mica, interbedded with brown clay and silt, locally } \\
\text { with some fine to coarse sand and gravel. }\end{array}$ \\
\hline & \multicolumn{2}{|c|}{ Ronkonkoma drift } & $\begin{array}{l}\text { Upper glacial aquifer } \\
\text { zone } \mathrm{B}^{\mathrm{a}}\end{array}$ & $\begin{array}{l}\text { Tan, gray, and brown, poorly to moderately sorted deposits of } \\
\text { medium to fine sand, silt, and some coarse sand and gravel, } \\
\text { with discontinuous lenses of moderately to well-sorted fine to } \\
\text { coarse sand, gravel, and some silt. }\end{array}$ \\
\hline & \multicolumn{2}{|c|}{ Lower glacial-lake clay } & Lower confining unit & $\begin{array}{l}\text { Gray silt, clay, silty clay, and sandy clay, commonly with } \\
\text { abundant mica, interbedded with brown clay and silt, and } \\
\text { locally with lenses of gray and brown silty sand and fine sand. }\end{array}$ \\
\hline & \multicolumn{2}{|c|}{$\begin{array}{l}\text { Montauk Till and associated } \\
\text { glaciofluvial deposits }\end{array}$} & $\begin{array}{l}\text { Upper glacial aquifer } \\
\text { zone } \mathrm{C}\end{array}$ & $\begin{array}{l}\text { Montauk Till consists of unsorted deposits of gravel, sand, silt, } \\
\text { and clay. Glaciofluvial deposits consist of fine to coarse and } \\
\text { gravel with thin lenses of silt and clay. }\end{array}$ \\
\hline & \multicolumn{2}{|c|}{ Marine clay } & Lower confining unit ${ }^{\mathrm{b}}$ & $\begin{array}{l}\text { Grayish-green, dark-gray, and brown clay, silty clay, and } \\
\text { sandy clay, locally with marine fossils and some thin lenses of } \\
\text { sand and gravel. }\end{array}$ \\
\hline & \multicolumn{2}{|c|}{ Nonmarine clay } & & $\begin{array}{l}\text { Mainly brown and reddish-brown clay, locally with thin beds } \\
\text { of silt and fine sand. }\end{array}$ \\
\hline$?$ & \multicolumn{2}{|c|}{ Post-Cretaceous(?) deposits } & $\begin{array}{l}\text { Upper glacial aquifer } \\
\text { zone } \mathrm{C}\end{array}$ & $\begin{array}{l}\text { Tan, gray, and brown poorly to well sorted deposits of fine to } \\
\text { coarse sand and gravel, with some silt and clay. }\end{array}$ \\
\hline \multirow{3}{*}{ 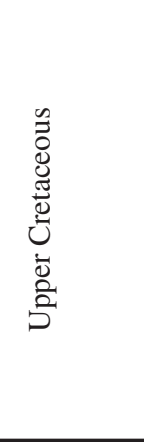 } & \multicolumn{2}{|c|}{$\begin{array}{l}\text { Matawan Group and Magothy } \\
\text { Formation, undifferentiated }\end{array}$} & Magothy aquifer & $\begin{array}{l}\text { Gray to white, fine to coarse sand with interstitial clay, silt, } \\
\text { lignite, interbedded with layers of gray clay, silt, and clayey } \\
\text { and silty sand, and lenses of lignite and pyrite. Coarse sand } \\
\text { and gravel generally present in basal 100-200 feet. }\end{array}$ \\
\hline & \multirow{2}{*}{$\begin{array}{l}\text { Raritan } \\
\text { Formation }\end{array}$} & $\begin{array}{l}\text { Unnamed clay } \\
\text { member }\end{array}$ & Raritan confining unit & $\begin{array}{l}\text { Multicolored clay, silty clay, and clayey and silty fine sand, } \\
\text { commonly with beds and lenses of lignite, pyrite, and sand, } \\
\text { and locally with thin beds of gravel. }\end{array}$ \\
\hline & & $\begin{array}{l}\text { Lloyd Sand } \\
\text { Member }\end{array}$ & Lloyd aquifer & $\begin{array}{l}\text { White and gray, fine to coarse sand and gravel, with } \\
\text { intercalated beds and lenses of gray clay, silt, clayey and silty } \\
\text { sand, and some lignite and pyrite. }\end{array}$ \\
\hline 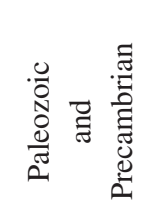 & \multicolumn{2}{|c|}{ Bedrock } & Bedrock & $\begin{array}{l}\text { Mainly gneiss and schist capped by a weathered zone of } \\
\text { greenish-white residual clay. }\end{array}$ \\
\hline
\end{tabular}

a Upper part of the Ronkonkoma drift is included in the upper glacial aquifer zone A where it is at the surface in the southern part of the study area.

b The lower glacial-lake clay, marine clay, and nonmarine clay are considered as one hydrogeologic unit in this study and are referred to as the lower confining unit. (See discussion in text.) 


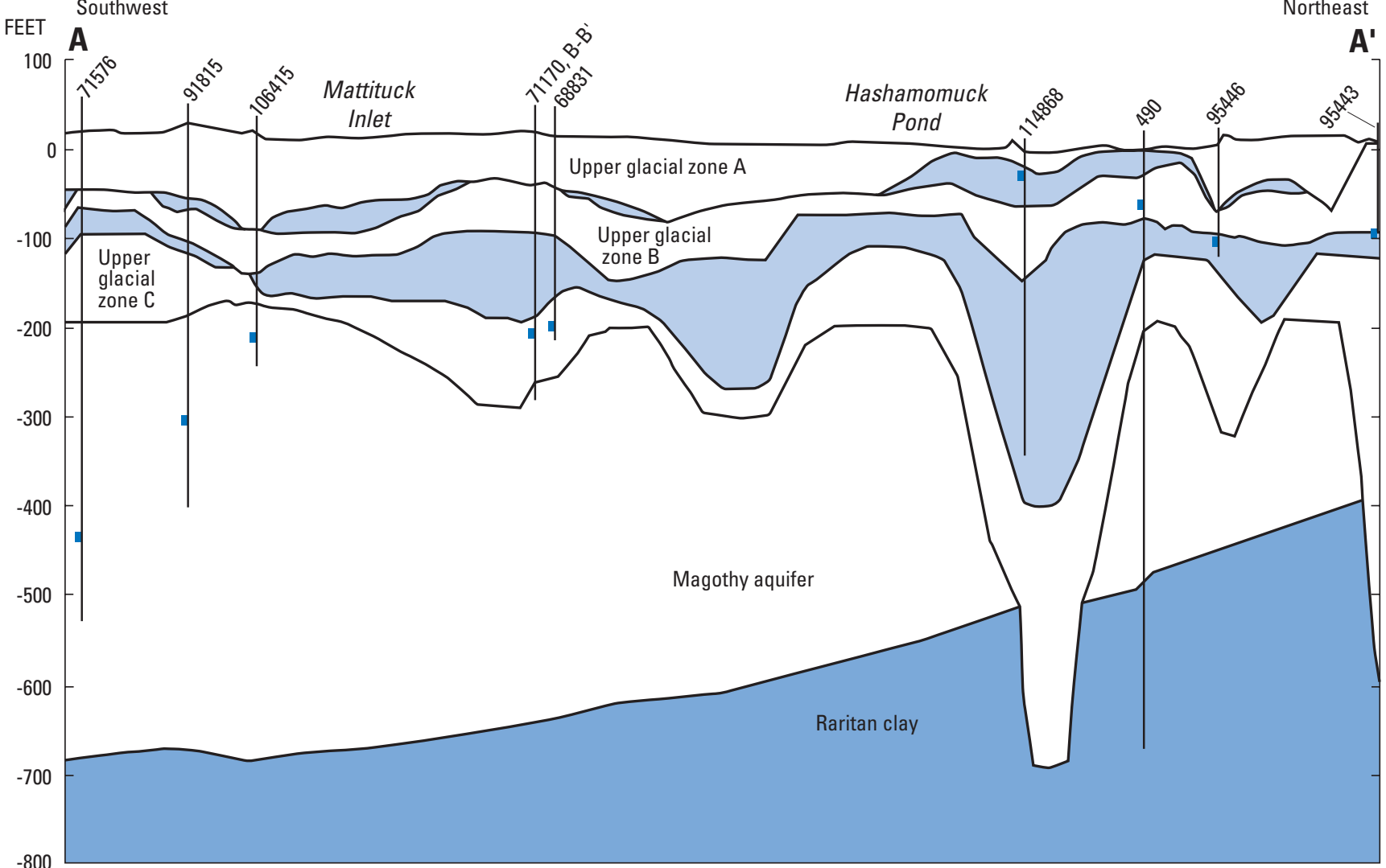

$-800$

\section{Northwest}

FEET

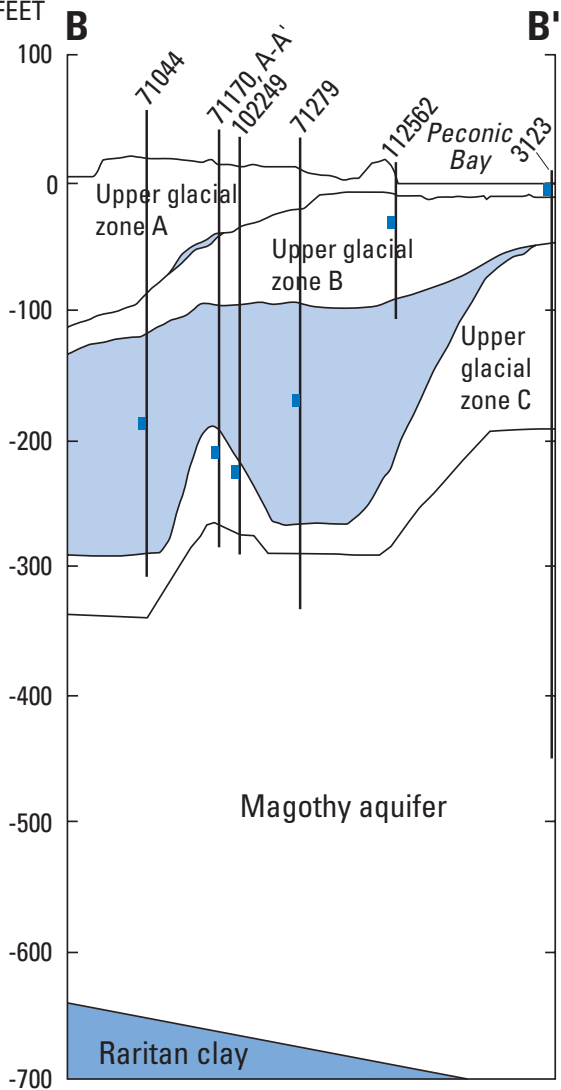

\section{EXPLANATION}

Pleistocene confining layer

Aquifer

Raritan Clay (not modeled)

Well and well number, flag is estimated altitude of freshwatersaltwater interface. Datum is NGVD of 1929.

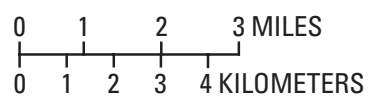

VERTICAL SCALE GREATLY EXAGGERATED

Figure 5. Sections A-A' and B-B' showing hydrogeologic units in the North Fork study area. (Traces of sections are shown in fig. 1) 


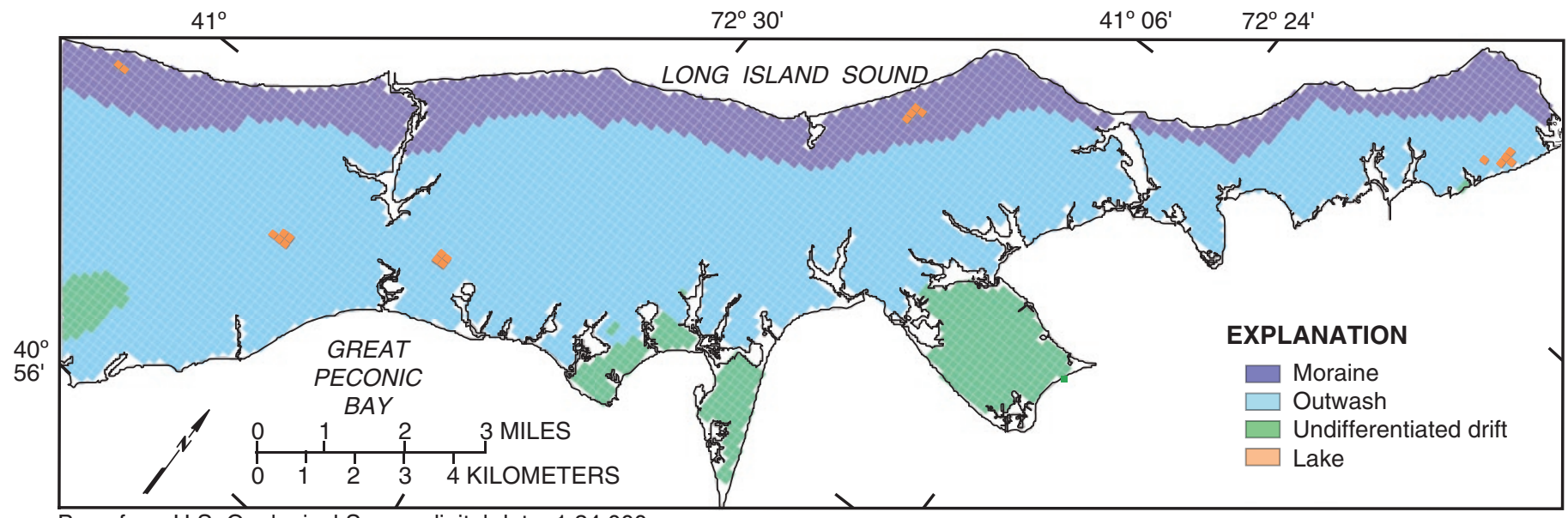

Base from U.S. Geological Survey digital data, 1:24,000,

Universal Transverse Mercator projection, NAD27, Zone 18

Figure 6. Surficial distribution of moraine, outwash, and drift on the North Fork, Suffolk County, N.Y. (Location is shown in fig. 1)

A. Lower surface altitude

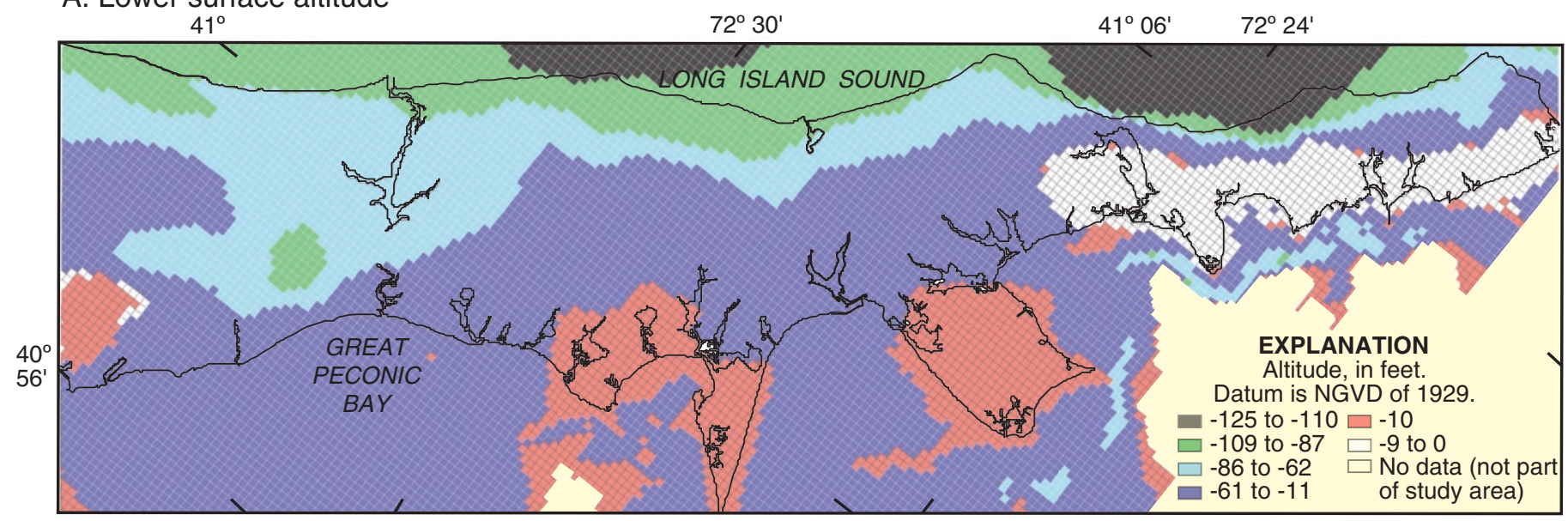

B. Thickness

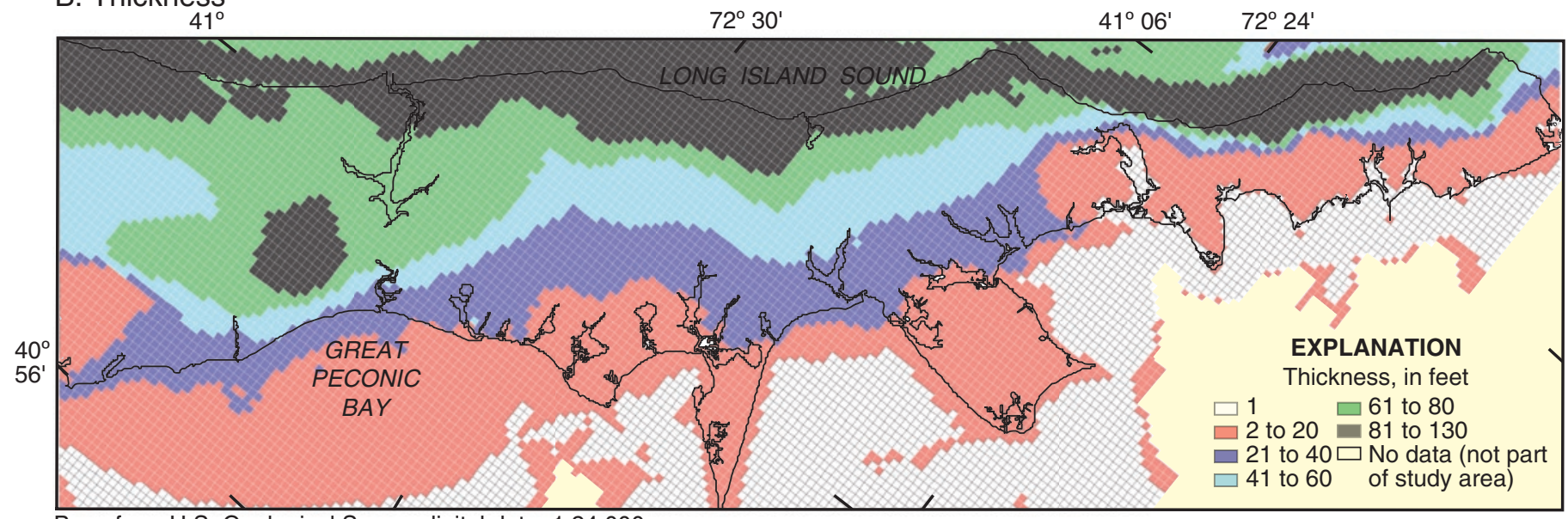

Base from U.S. Geological Survey digital data, 1:24,000,

Universal Transverse Mercator projection, NAD27, Zone 18

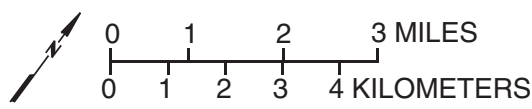

Figure 7. Lower surface altitude and thickness of the upper glacial aquifer zone A on North Fork, Suffolk County, N.Y.: A. Lower surface altitude. B. Thickness. (Location is shown in fig. 1) 
A. Lower surface altitude

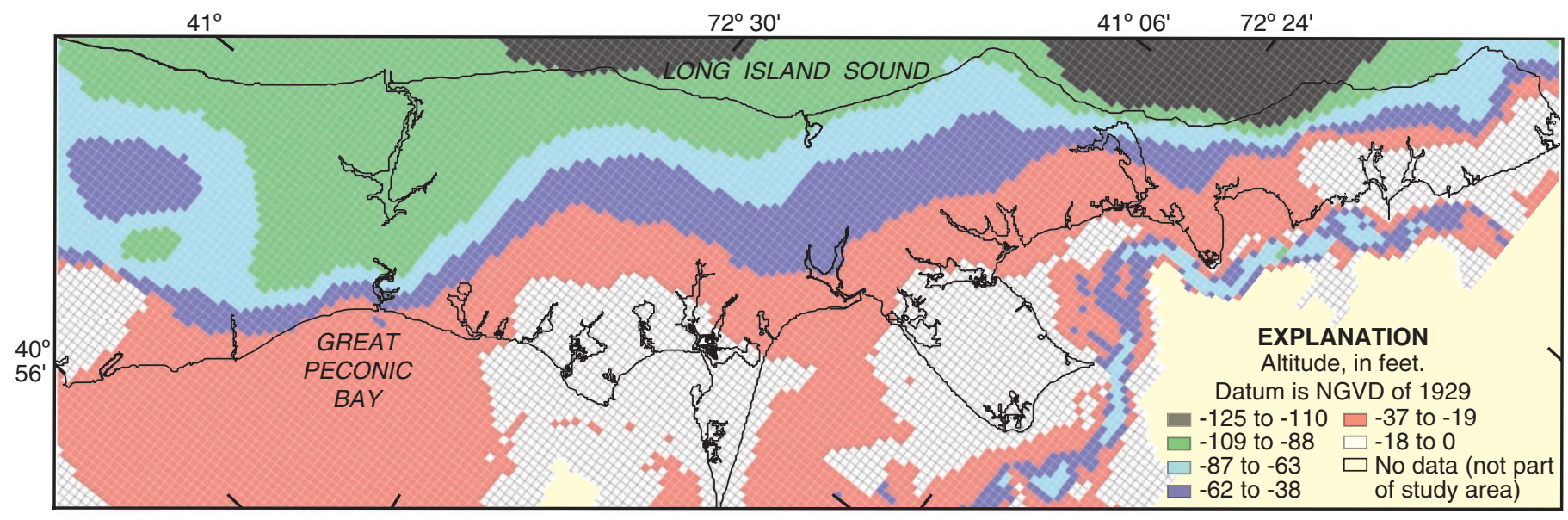

B. Thickness

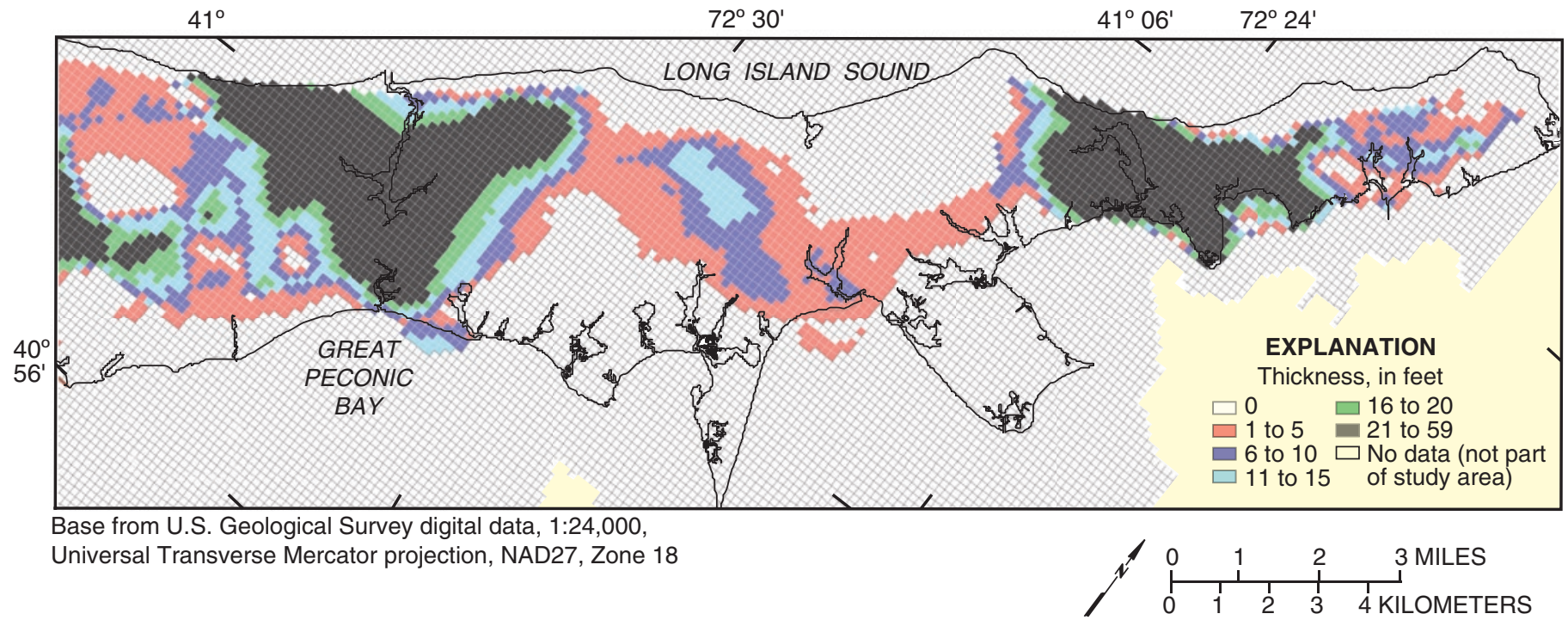

Figure 8. Lower surface altitude and thickness of the upper confining unit on North Fork, Suffolk County, N.Y.: A. Lower surface altitude. B. Thickness. (Location is shown in fig. 1) 
A. Lower surface altitude

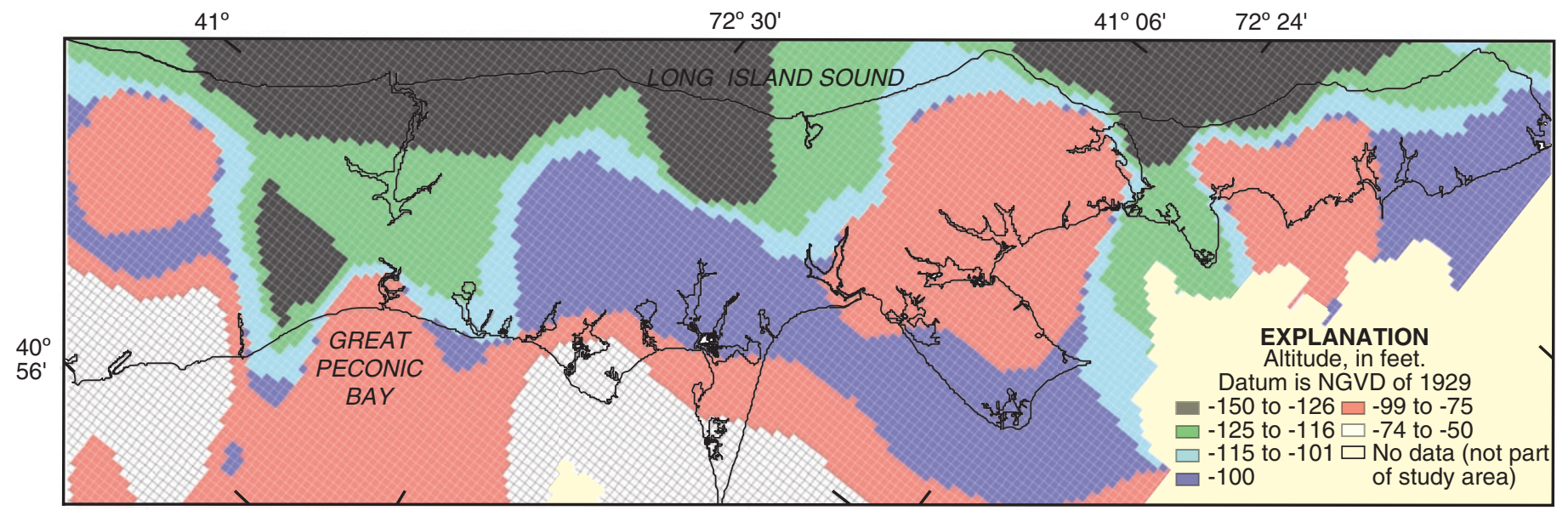

B. Thickness

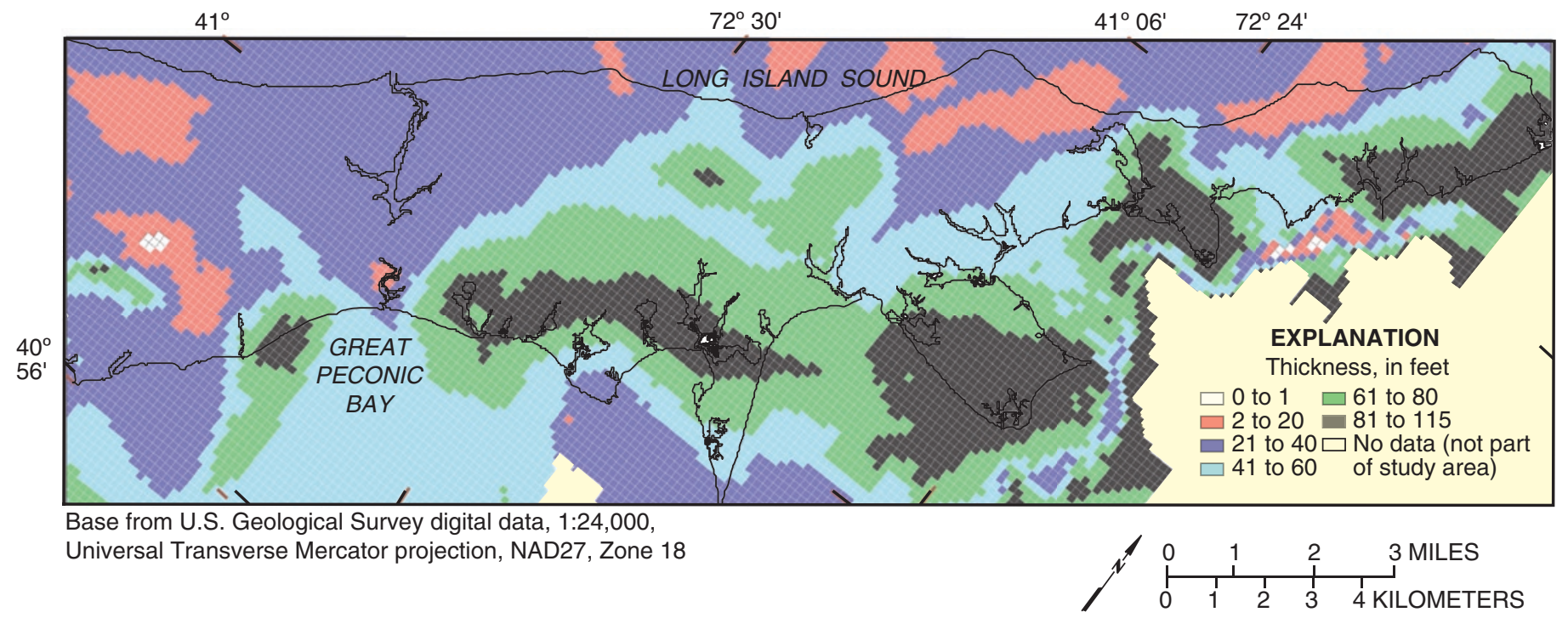

Figure 9. Lower surface altitude and thickness of the upper glacial aquifer zone B on North Fork, Suffolk County N.Y.: A. Lower surface altitude. B. Thickness. (Location is shown in fig. 1) 


\section{A. Lower surface altitude}

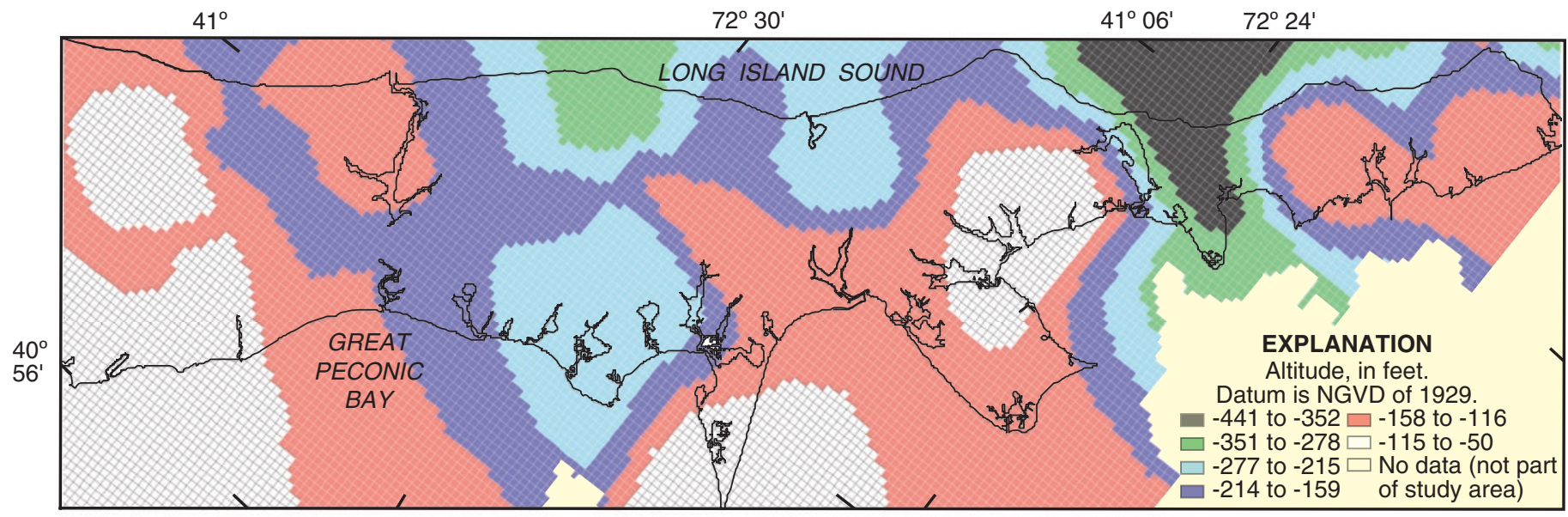

B. Thickness

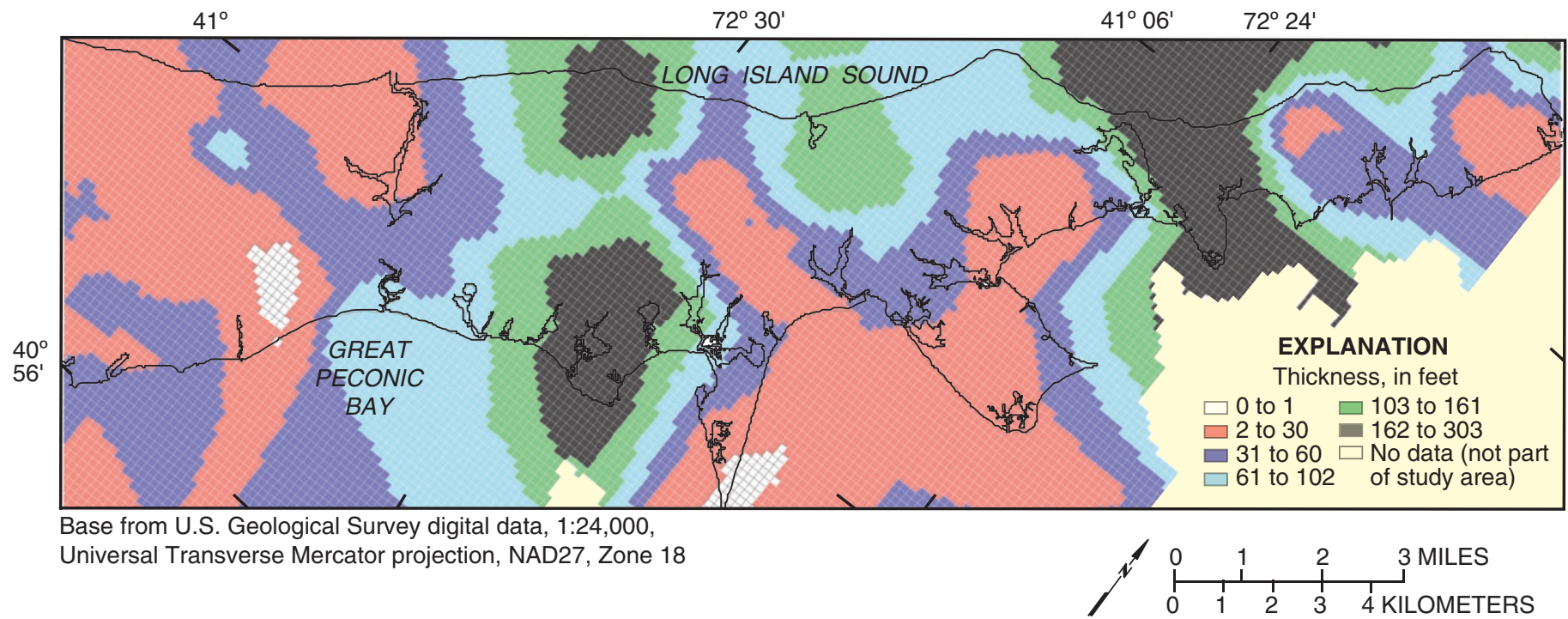

Figure 10. Lower surface altitude and thickness of the lower confining unit on North Fork, Suffolk County, N.Y.: A. Lower surface altitude. B. Thickness. (Location is shown in fig. 1) 
A. Lower surface altitude

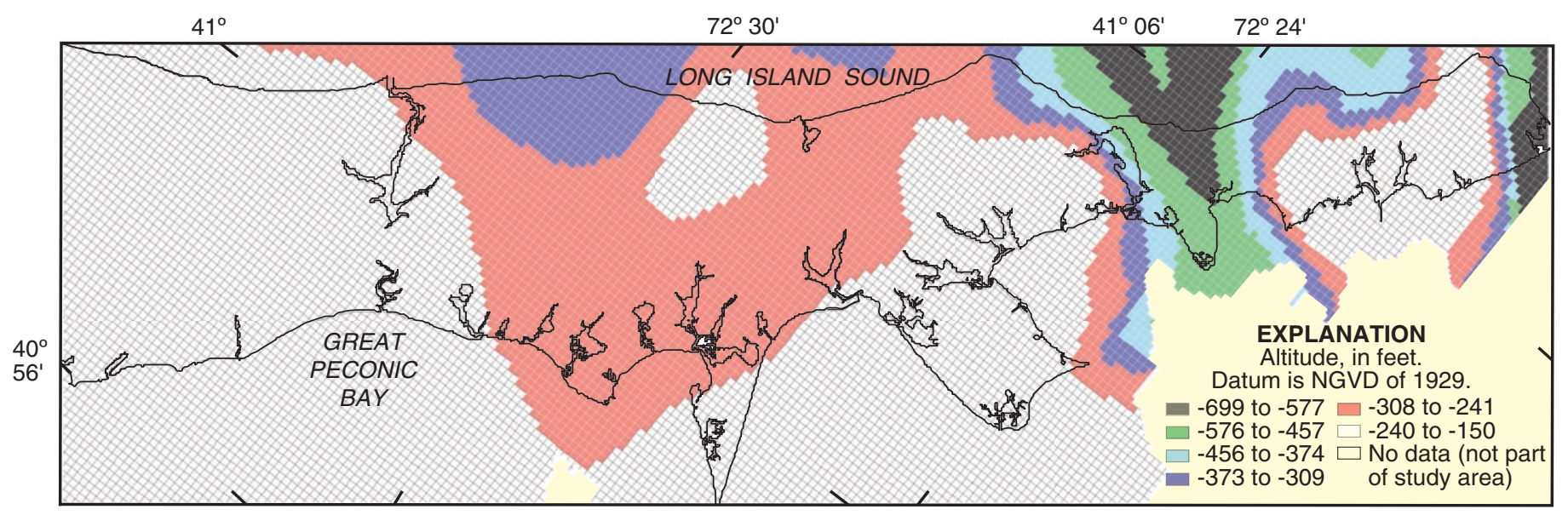

B. Thickness

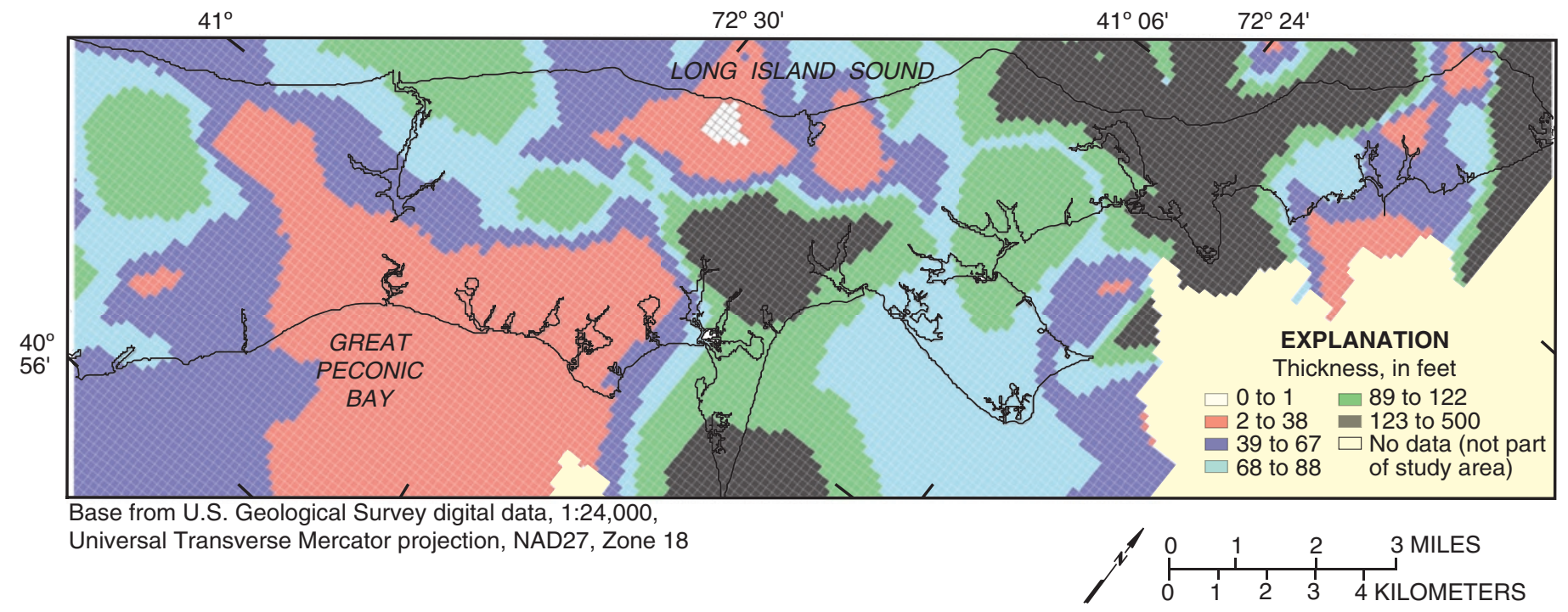

Figure 11. Lower surface altitude and thickness of the upper glacial aquifer zone $C$ on North Fork, Suffolk County, N.Y.: A. Lower surface elevation. B. Thickness. (Location is shown in fig. 1) 
A. Upper surface altitude

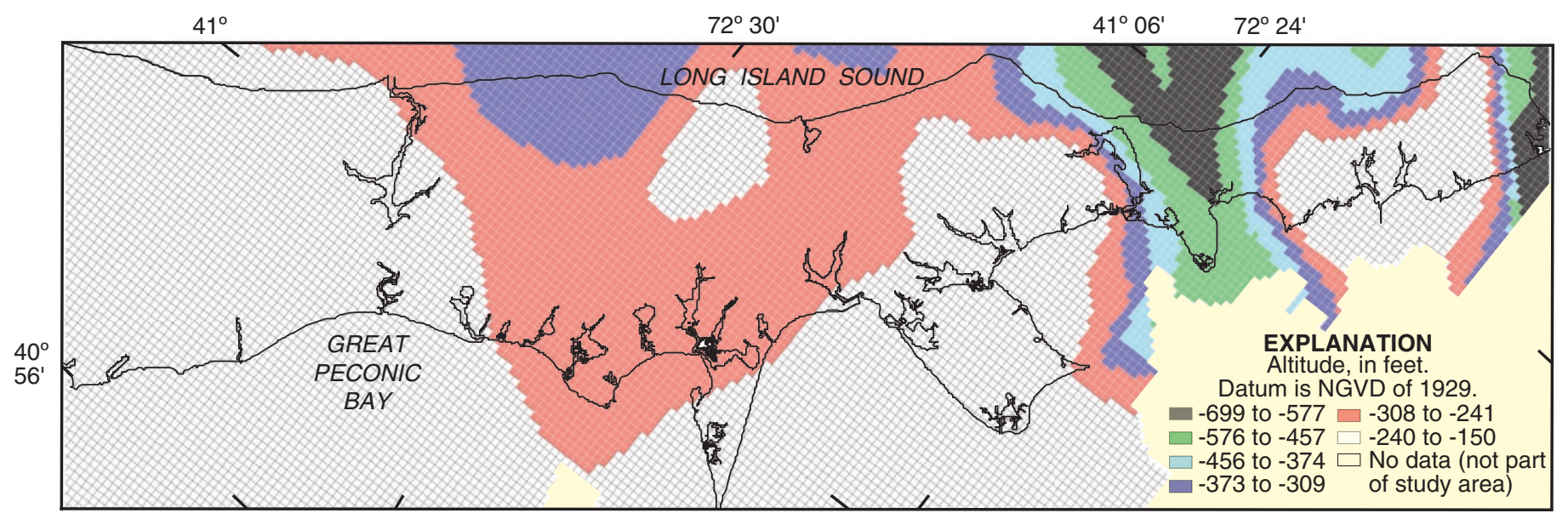

B. Lower surface altitude

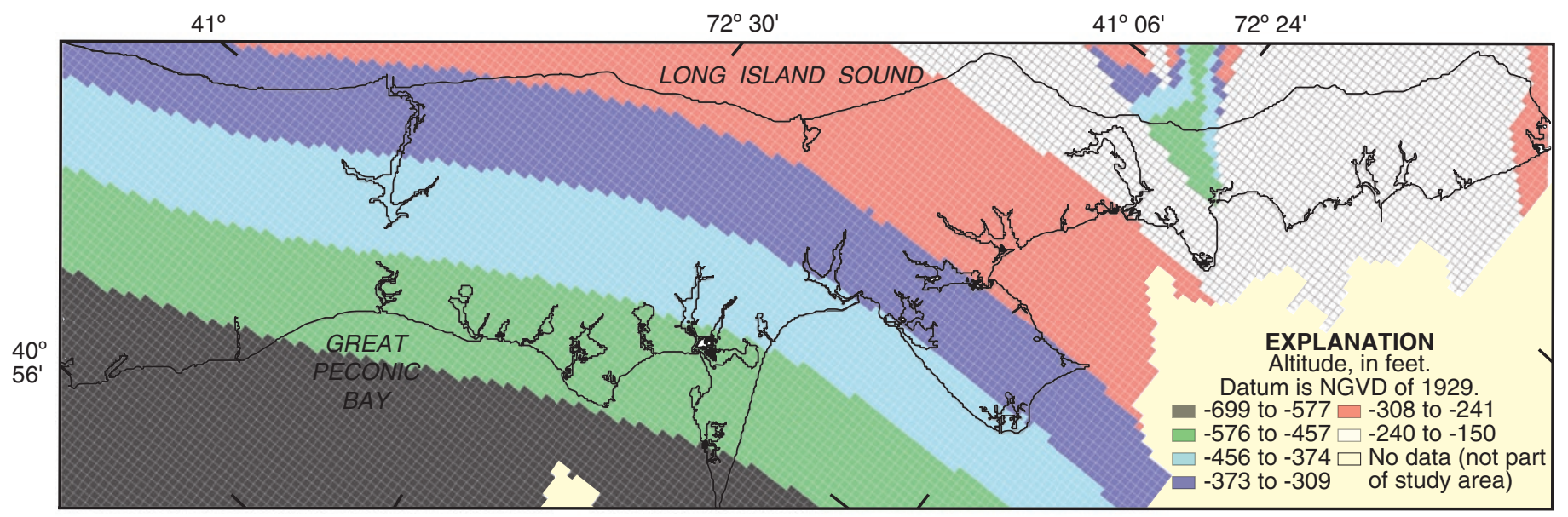

C. Thickness

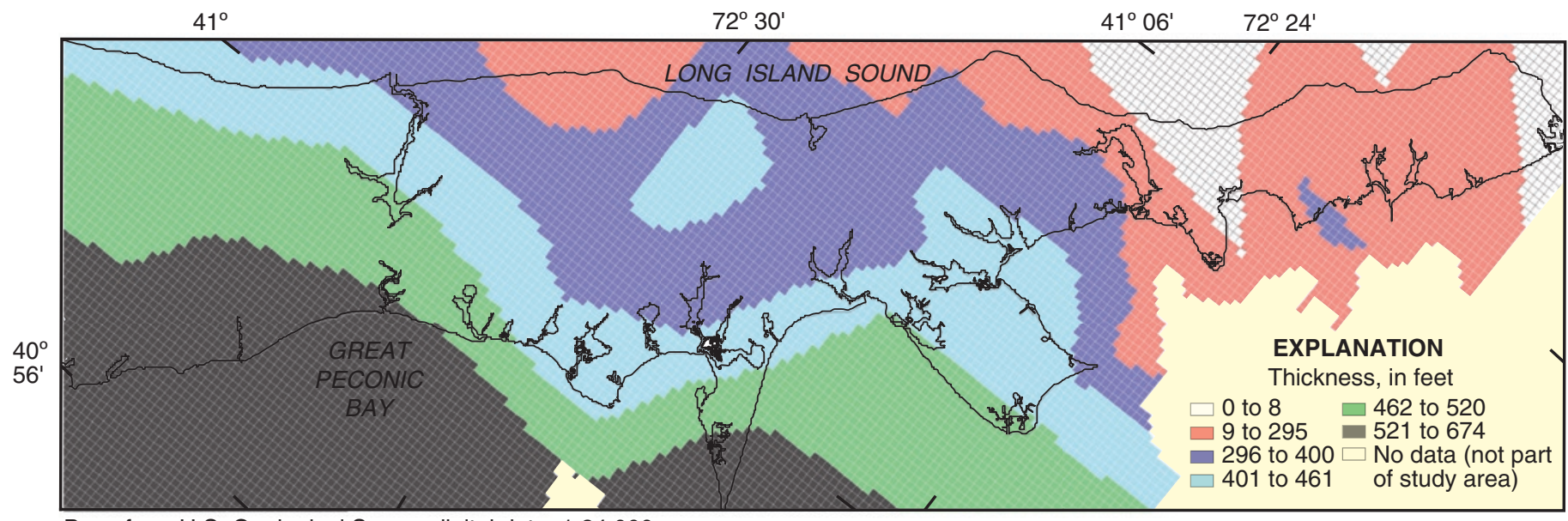

Base from U.S. Geological Survey digital data, 1:24,000,

Universal Transverse Mercator projection, NAD27, Zone 18

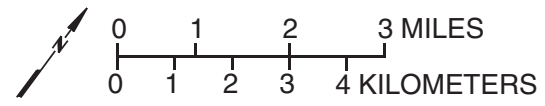

Figure 12. Upper and lower surface altitude and thickness of the Magothy aquifer on North Fork, Suffolk County, N.Y.: A. Upper surface elevation. B. Lower surface elevation. C.Thickness. (Location is shown in fig. 1) 
A. Upper confining unit

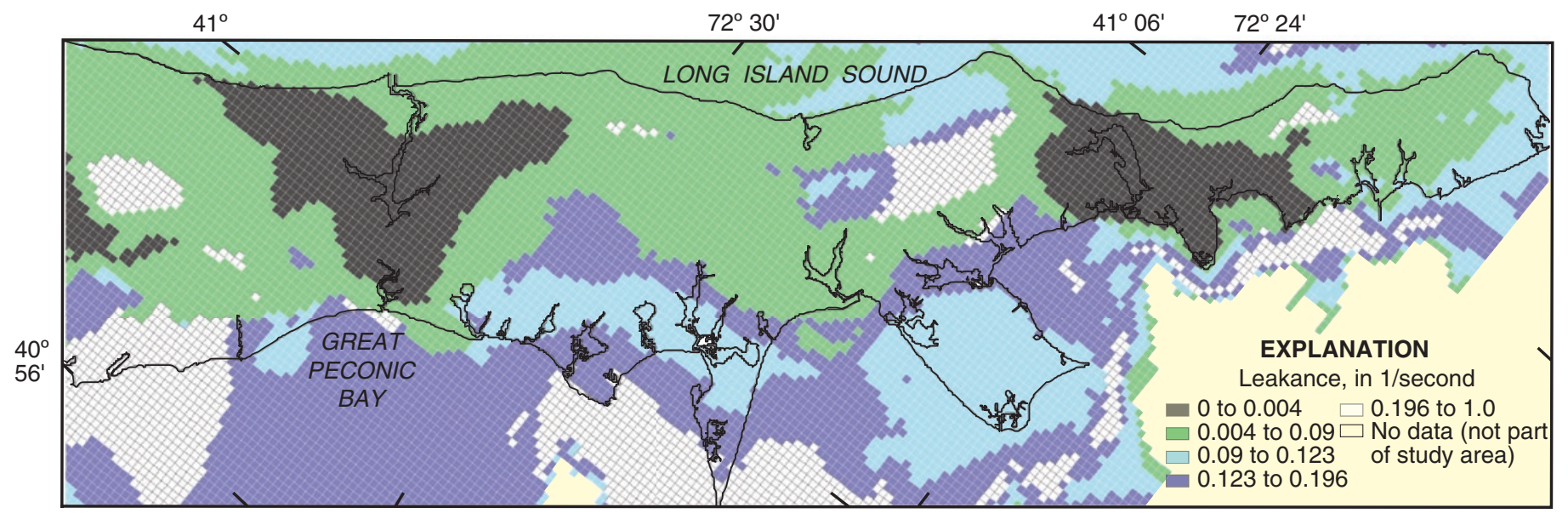

B. Lower confining unit

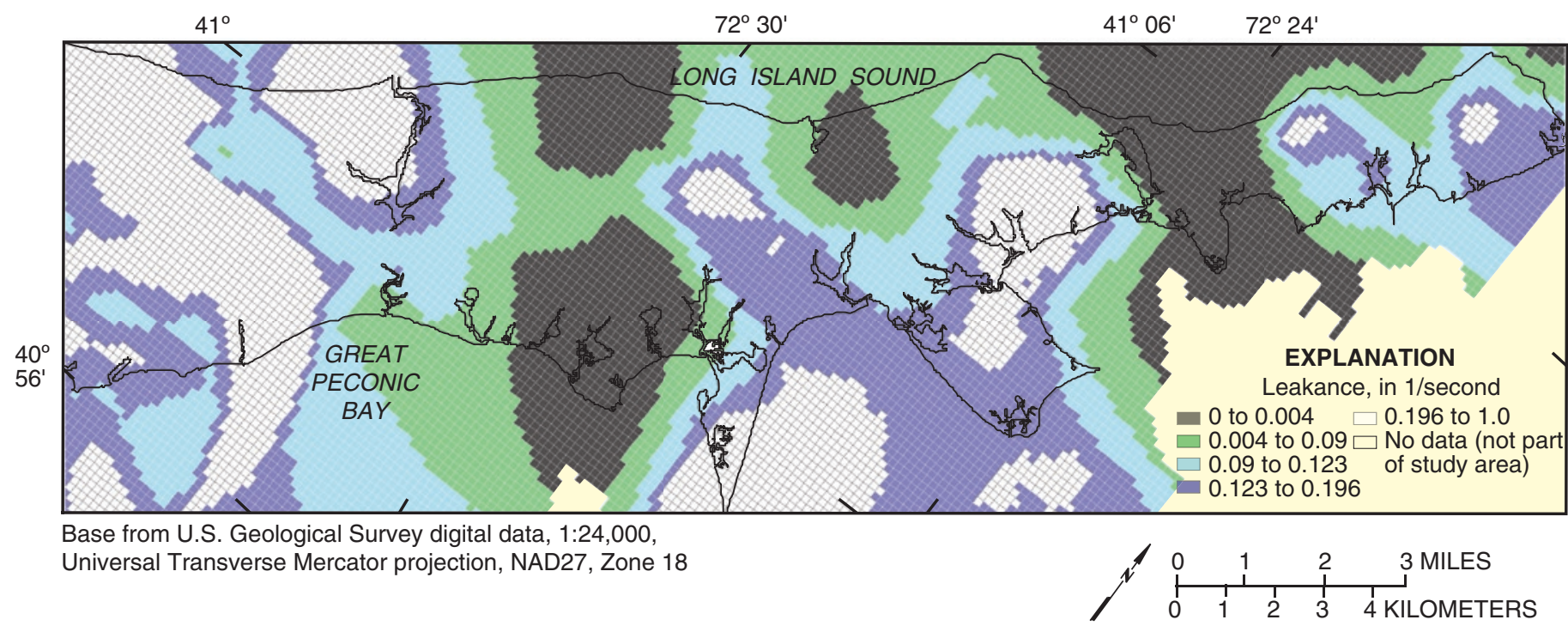

Figure 13. Vertical leakance values for the Pleistocene upper and lower confining units on the North Fork, Suffolk County, N.Y:: A. Upper confining unit. B. Lower confining unit. (Location is shown in fig. 1)

Table 2. Hydraulic conductivity of Pleistocene and uppermost Cretaceous hydrogeologic units for North Fork mode [From Schubert and others, 2003. Dashes indicate no value was estimated.]

\begin{tabular}{lccc}
\hline & \multicolumn{2}{c}{ Hydraulic conductivity } & Ratio of \\
\cline { 2 - 4 } \multicolumn{1}{c}{ Hydrogeologic unit } & Horizontal (feet per day) & Vertical (feet per day) & 10:1 \\
hporizontal to vertical & $10: 1$ \\
Upper glacial aquifer zone A Outwash & 200 & 20 & $10: 1$ \\
Upper glacial aquifer zone A Moraine & 80 & 8 & -- \\
Upper confining unit & 200 & 20 & 0.4 \\
Upper glacial aquifer zone B & -- & 20 & $10: 1$ \\
Lower confining unit & 200 & 0.1 & -- \\
Upper glacial aquifer zone C & -- & 30 & $10: 1$ \\
Magothy aquifer & 300 & 0.5 & $100: 1$ \\
\hline
\end{tabular}




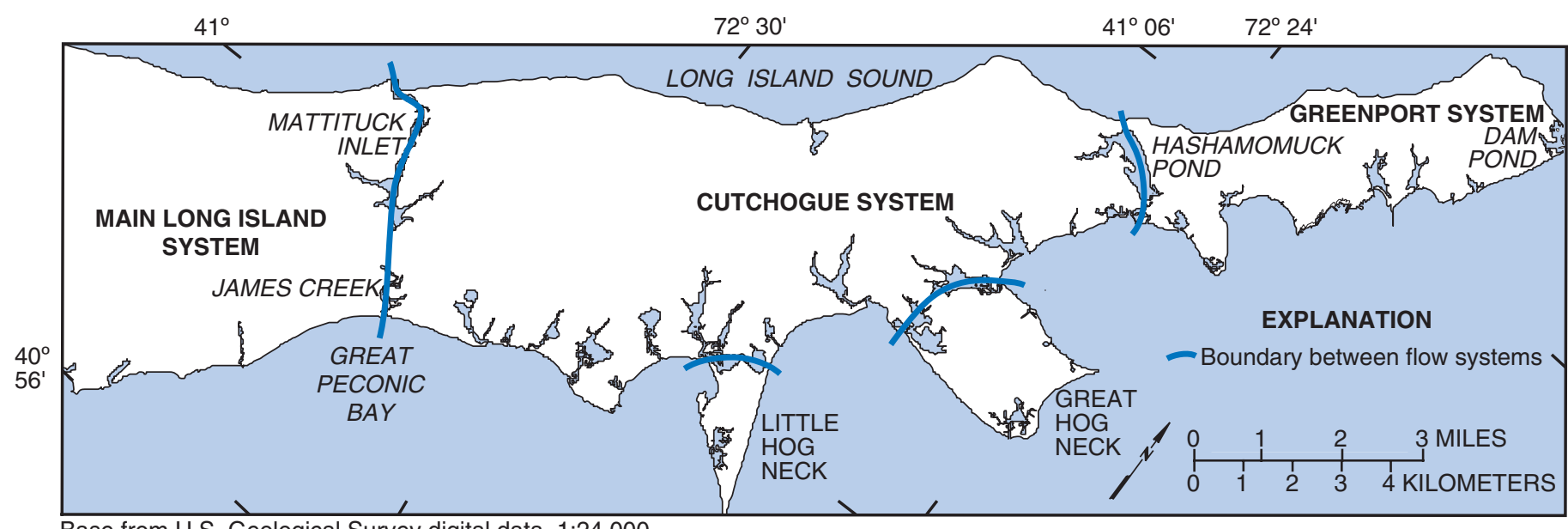

Base from U.S. Geological Survey digital data, 1:24,000,

Universal Transverse Mercator projection, NAD27, Zone 18

Figure 14. Location of local freshwater flow systems on North Fork, Suffolk County, N.Y. (Location is shown in fig. 1)

$\operatorname{Kv}(\mathrm{x}, \mathrm{y})_{\text {lower }}, \mathrm{Kv}(\mathrm{x}, \mathrm{y})_{\text {upper }}, \mathrm{Kv}(\mathrm{x}, \mathrm{y})_{\text {conf }}=$ vertical hydraulic conductivity [length/time] of lower unit, upper unit, and confining unit, respectively. These are functions of horizontal location $\mathrm{x}, \mathrm{y}$.

Porosity of all aquifers has been assumed to average 30 percent (Franke and Cohen, 1972). Porosity of the glacial aquifer of western Cape Cod has been estimated by Masterson and others (1997) to average about 35 percent.

\section{Hydrologic System}

The fresh ground-water flow system on the North Fork consists of a series of five hydraulically isolated lenses that are bounded below (and laterally in areas near the shore) by saltwater (fig. 14). The westernmost system, in the area west of Mattituck Inlet and James Creek (fig. 14), is part of the flow system of the main body of Long Island. The area to the northeast of these creeks and southwest of Hashamomuck Pond contains the Cutchogue flow system. Great Hog Neck and Little Hog Neck, along the southern shore of the North Fork, represent two isolated flow systems. The area east of Hashamomuck Pond and west of Dam Pond contains the Greenport flow system.

The movement of fresh ground water within each freshwater system on the North Fork is controlled by the hydraulic characteristics of the stratigraphic units and the distribution of hydrologic boundaries. Ground water generally flows seaward and downward from water-table mounds in the center of the peninsula, although the downward flow component may be diverted laterally by local confining layers. The lateral (seaward) flow curves upward near the shore, which is a discharge boundary.

\section{Hydrologic Boundaries}

The hydrologic boundaries of each freshwater system on the North Fork control the rate at which water enters and exits the system. The upper boundary on land is the water table; in offshore areas it is the sea floor. The lateral and lower boundaries are freshwater-saltwater interfaces. Freshwater recharge occurs where precipitation infiltrates the soil and reaches the water table; it also occurs in unsewered areas as return flow of used public-supply water through septic systems. Natural discharge occurs in offshore areas either as upward seepage through the sea floor into saline surface waters or as seepage through confining layers into sediments bearing saline ground water. Discharge also occurs where the land surface intersects the water table (such as in streams, ponds, and wetlands); here freshwater exits the system as seepage (base flow) to streams and through evapotranspiration. The lower boundary of each freshwater flow system is a zone of diffusion that separates freshwater from the denser saltwater. This lower boundary moves gradually in response to changes in the balance between recharge and discharge within the system, including in response to pumping.

Precipitation and Recharge.-- The main source of recharge on the North Fork is precipitation. Not all precipitation that falls on land surface becomes recharge, however, because some is lost through evapotranspiration or as surface runoff to streams. Precipitation rates are fairly uniform throughout the year (Peterson, 1987), but most recharge occurs during the fall, winter, and early spring because nearly all precipitation during the summer growing season is lost through evapotranspiration. The seasonal differences in recharge rate generally are greater than any annual or longer term fluctuations. Long-term precipitation records from stations in Bridgehampton, Riverhead, and Greenport (fig. 1) were the sources of precipitation data used in this study; the seasonal and annual precipitation values, and the values of recharge from land surface and lakes calculated from data from these stations, are given in appendix 5. Long-term (1959-99) mean annual precipitation totals for Bridgehampton, Greenport, and Riverhead are 46.08 in., 44.91 in., and 45.33 in., respectively. Most of the long-term mean precipitation that falls from 
October 15 through May 15 (82 percent is used for the calculation) becomes ground-water recharge; no significant amount of precipitation becomes ground-water recharge during the remainder of the year (Steenhius and others, 1985).

Ground-Water Discharge.-- Most natural fresh groundwater discharge in the study area occurs as shoreline or subsea underflow; the rest occurs as stream base flow and through pond and wetland evapotranspiration. Periodic streamflow measurements are available for sites along Meetinghouse Creek and Moores Drain (fig. 1). The historical mean base flow of Meetinghouse Creek, calculated from 17 measurements made during 1949-58, a period of average precipitation, is about $1.42 \mathrm{ft}^{3} / \mathrm{s}$ (Schubert, 1999). Streamflow measurements made in 1998-99 at Moores Drain (table 3) indicate its base flow to be generally less than $0.1 \mathrm{ft}^{3} / \mathrm{s}$, although it may be 1.48 $\mathrm{ft}^{3} / \mathrm{s}$ or more for a few days after storms.

Table 3. Discharge of Moores Drain at Route 25 in Greenport, Suffolk County, N.Y., on four sampling dates in 1998-99

[Location is shown in fig. 20A.]

\begin{tabular}{cc}
\hline Date (mo/d/yr) & Discharge (cubic feet per second) \\
\hline $5 / 28 / 98$ & 0.02 \\
$7 / 1 / 98$ & 1.48 \\
$8 / 24 / 98$ & 0.04 \\
$5 / 12 / 99$ & 0.09 \\
Mean & $\mathbf{0 . 4 1}$ \\
Median & $\mathbf{0 . 0 7}$ \\
\hline
\end{tabular}

\section{Freshwater-Saltwater Interface}

The freshwater-saltwater interface is a transition zone that results from the mixing of waters through diffusion and mechanical dispersion (Essaid, 1990). In this study, the interface is conceptualized as a moving, impermeable, sharp boundary resulting from the density difference between completely fresh water and salty water. This conceptualization is a simplification that does not allow for mixing and is more accurate at regional scales than at localized scales, such as that of an individual well undergoing saltwater intrusion. A sharp boundary moves landward or seaward in response to changes in head. The position of the freshwater-saltwater interface, conceptualized as a sharp boundary, has been delineated by Schubert and others (2003) from data from filter-press core samples, water samples collected through a screened auger, and borehole geophysical logs in accordance with the approach described by Schubert (1999). The freshwatersaltwater interface location was specified as the point where chloride concentration was about $250 \mathrm{mg} / \mathrm{L}$ (from filter-press core samples) or where specific conductance was estimated to be $500 \mu \mathrm{S} / \mathrm{cm}$.

The freshwater-saltwater interface on the North Fork is near sea level at the shores and descends inland through the unconfined and shallow confined parts of the flow system in general conformance with the Ghyben-Herzberg principle, which states that the freshwater thickness extends $40 \mathrm{ft}$ below sea level for $1 \mathrm{ft}$ of freshwater head above sea level. The interface below the upper surface of the lower confining unit may extend seaward of its position directly above this unit, particularly near the western end of the North Fork as a result of impedance by the overlying clay. The interface descends westward within the Magothy aquifer and generally is deepest near the western end of the North Fork, where the water table is highest and where some freshwater enters the system from upgradient parts of Long Island's main flow system. The interface ascends eastward where the North Fork narrows. The interface within the Cutchogue flow system, where the Magothy aquifer contains mostly salty water, generally is as high as the base of the upper glacial aquifer; in the other flow systems it is within the shallow confined parts of the upper glacial aquifer or extends only through the unconfined zone.

\section{Ground-Water Levels}

Ground-water levels were measured at 246 wells by the USGS and Suffolk County Department of Health Services during March-April 1994 and were used by Schubert (1998) to map the water-table altitude in the study area (fig. 15). Groundwater levels on the North Fork respond to seasonal and annual variations in recharge from precipitation and, to a lesser extent, to seasonal variations in water use. The water table generally declines from May through early October, when recharge is lowest and water use is greatest, and generally rises from the end of October through the end of April, when recharge is greatest and water use is lowest (Nemickas and Koszalka, 1982). Seasonal variations in water levels within a given year generally exceed the annual and longer term fluctuations. The water-table altitude decreases to zero near the shore.

\section{Effects of Pumping and Drought on Ground-Water Levels and the Freshwater-Saltwater Interface}

The freshwater-saltwater interface on the North Fork moves downward and seaward in response to recharge, or upward and landward in response to withdrawals such as pumping or decreased recharge during drought. Consequently, overpumping creates a potential for saltwater intrusion into public-supply wells, especially during drought conditions. Concern over the effect of increased future pumping on the interface prompted the development of a model to simulate several pumping and drought scenarios.

The effects of pumping and drought on the freshwatersaltwater interface were evaluated through two sets of pumping scenarios-four under average long-term precipitation (recharge) conditions, projected to the year 2020 , followed by the same four simulations under drought 
Summary of water-supply scenarios for years 2006-20 (four based on average-recharge conditions, and four based on average conditions except during 5-year drought (2011-15) in North Fork model, Suffolk County, N.Y.

[Percent increases are in relation to scenario 1 rates.]

\begin{tabular}{|c|c|c|c|c|}
\hline Scenario & $\begin{array}{l}\text { Public-supply } \\
\text { pumpage }\end{array}$ & $\begin{array}{l}\text { Public-supply } \\
\text { return flow }\end{array}$ & $\begin{array}{l}\text { Commercial } \\
\text { pumpage }\end{array}$ & $\begin{array}{l}\text { Miscellaneous } \\
\text { pumpage }\end{array}$ \\
\hline
\end{tabular}

Scenarios based on average recharge from precipitation

\begin{tabular}{lllll}
1 & 1998 rates & 1998 rates & 1994 rates & 1999 rates \\
2 & 186-percent increase & 47-percent increase & no increase & no increase \\
3 & 268-percent increase & 68-percent increase & no increase & no increase \\
4 & 365-percent increase & 92-percent increase & 157-percent increase & no increase \\
\hline
\end{tabular}

\section{Scenarios based on drought conditions}

Drought was applied to the above scenarios as a 20-percent decrease from long-term rate of recharge from precipitation and a 20-percent increase from 1999 agricultural pumpage during years 2011-15.

conditions. Total annual public-supply and miscellaneous pumpage for the four scenarios were as follows:

Public-supply pumpage was varied over two 6-month seasons-from May through October (summer) and from November through April (winter), with winter pumpage applied at about 50 percent of the summer pumpage rate. Miscellaneous pumpage had a 3-month summer season (from June through August) and a 9-month winter season (from September through May), where winter miscellaneous pumpage was applied at 50 percent of the summer rate. The 5-year drought (years 2011-15) in the second set of scenarios was represented by a 20-percent decrease in annual recharge with an offsetting equivalent increase in the agricultural irrigation requirement.

\section{Development of Flow Model}

The freshwater-saltwater interface is not a sharp surface, but a zone of diffusion that is difficult to simulate; therefore, appropriate simplifying assumptions generally are made that provide a reasonable approximation of the relation between saline and fresh ground water (Reilly, 1993). The two most common methods of simulating this relation are the sharpinterface approach and the variable-density approach. In the sharp-interface approach, the system is assumed to consist of two immiscible fluids (Essaid, 1990); in the variable-density approach, it is assumed that one miscible fluid transports a solute, and the solute affects the density and viscosity of the fluid. The variable-density approach also includes the effects of dispersion and chemical reactions associated with advective movement. The sharp-interface approach is preferred if only general estimates of the location of the freshwater-saltwater interface are desired; the less tractable variable-density approach is used if estimates of local dissolved-chloride concentrations in water are desired. A comprehensive review of the hydrologic conditions near freshwater-saltwater environments, and the methods of flow analysis, are given in Reilly (1993).

The aquifer system of the North Fork was simulated through use of the SHARP model code (Essaid, 1990). SHARP is a quasi-three-dimensional finite-difference code

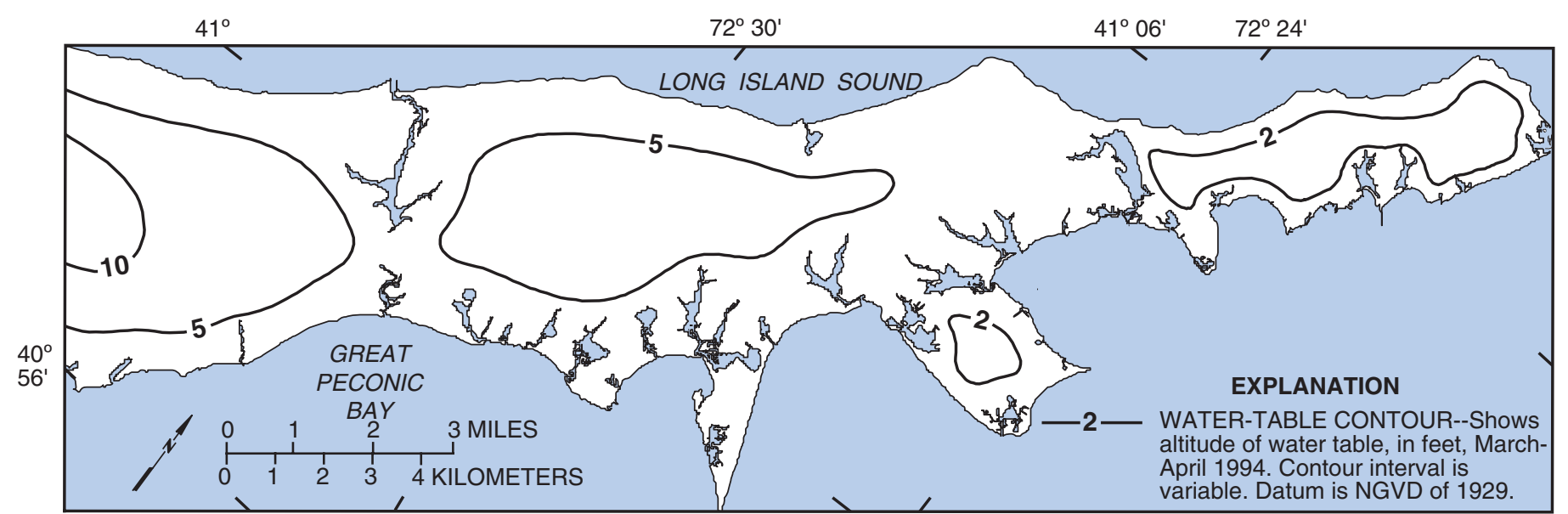

Base from U.S. Geological Survey digital data, 1:24,000, Universal Transverse Mercator projection, NAD27, Zone 18

Modified from Schubert, 1997, pl. 1

Figure 15. Water-table altitude in March-April 1994 on North Fork, Suffolk County, N.Y. (From Schubert, 1998, pl. 1.) (Location is shown in fig. 1) 
that simulates freshwater and saltwater flow in layered coastal aquifers by coupling two mathematical equations representing the freshwater and saltwater flow. The equations are coupled because the fresh and saline fluids share a boundary at the interface. The parabolic partial-differential equations are solved simultaneously for freshwater and saltwater head. Once the heads are calculated, the interface elevation is calculated by an equation for continuity of fluid pressure at the interface according to the Ghyben-Herzberg relation. A given model cell is characterized as a freshwater cell if the calculated altitude of the interface is at the base of the cell or below it; as a saltwater cell if the interface is at or above the top of the cell, or as a mixed-water cell if the interface is within the cell. The intersection of the interface with the top or bottom of an aquifer cell is termed the tip or toe of the interface, respectively (fig. 16), and its location is determined by extrapolation of the calculated interface slope at the center of surrounding model cells. Applying a transient stress near an interface will cause the interface to move as a function of time. For example, an increase in pumping that causes a decrease in seaward freshwater flow will cause the interface to move landward and upward. Depending on the rate of interface movement over a given time interval, the interface may rise above the base of a freshwater cell and cause that cell to become a mixed-water cell or a saltwater cell.

The SHARP method introduces inaccuracies concerning the potability limit with respect to chloride concentrations, and local upconing at well screens. In a SHARP model, the zone in which freshwater and saltwater mix is assumed to be abrupt even though it is probably hundreds to thousands of feet wide, as indicated by measured chloride concentrations. This characteristic of the real-world interface implies that the boundary between potable and impotable water is landward of the simulated SHARP interface. Spitz (1998) has noted that, because ground-water velocities within the mixing zone vary, simulated movement of a SHARP interface can be

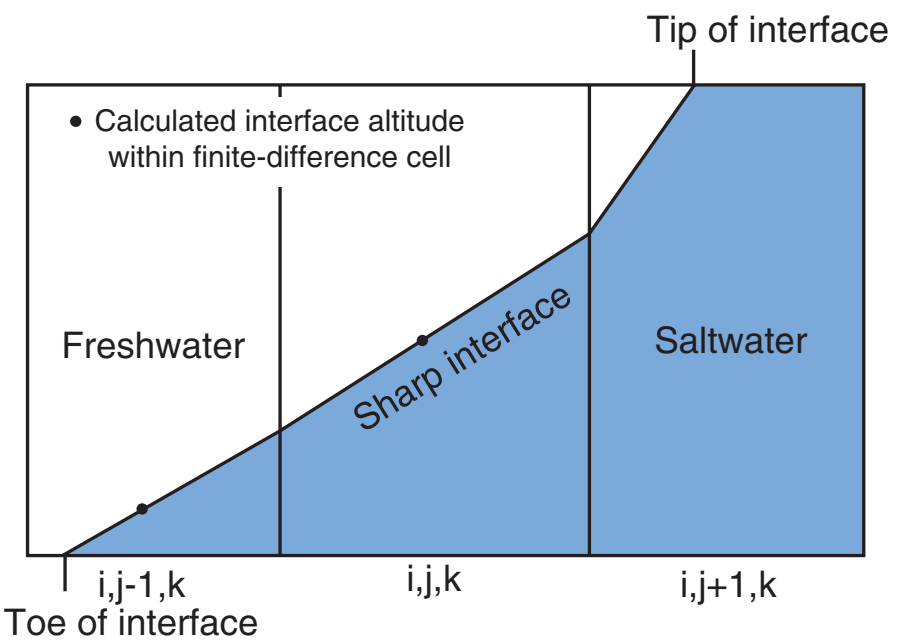

Figure 16. Schematic representation of the freshwatersaltwater interface along model row i, layer k, columns j-1, j and j+1. (Modified from Essaid, 1990) much smaller than the estimated movement of the "potability interface" (representing the approximate location of the 250$\mathrm{mg} / \mathrm{L}$ chloride concentration). Ground-water velocities are affected locally by pumping, and the effects of local upconing at wells are thus underrepresented.

\section{Model Grid}

The model grid was constructed to represent quasithree-dimensional flow through the sequence of aquifers and confining units described by Schubert and others (2003) and summarized in the earlier section Hydrogeologic Framework. The method of representation is summarized in the following paragraphs as a sequence of logical conditions applied on a cell-by-cell basis.

The model grid was oriented north-south (fig. 17) with 182 rows, 168 columns, and 4 layers. Each grid cell represents a 500-ft x 500-ft square, and thickness varies from cell to cell. The complete grid contains 44,312 active cells and 3,960 inactive cells. The study area is indicated by the smaller rotated rectangle in figure 17, and is used in most other illustrations throughout this report. The southeastern corner of the study-area rectangle extends beyond the model grid; this nondiscretized area is masked by map explanations in the other illustrations.

The model layers generally represent the upper glacial aquifer zones A, B, and C and the Magothy aquifer. Modellayer thickness is assigned an integer value, in feet, with a $1-\mathrm{ft}$ minimum. The upper boundary of the top layer represents the water table on land and the sea floor offshore. The onshoreoffshore boundary is a discretized coastline that is shown together with modeled sea-floor depth in figure 18. Onshore cells with three sides facing offshore were not permitted because of a limitation in the SHARP method used to calculate the interface elevation. The thickness of the onshore (partly saturated) zone of the unconfined aquifer depends on the water-table altitude, whose maximum was specified at $20 \mathrm{ft}$ above sea level. The model represents the upper glacial aquifer zone A as three distinct hydraulic zones in its top layer; these correspond to the moraine, outwash, and drift units depicted in figure 6 . Where aquifer units pinch out in other model layers, a 1-ft layer thickness is assigned together with hydraulic-property values corresponding to those of an overlying or underlying aquifer unit.

Layer-bottom elevation is represented as an integer value and generally corresponds to the bottom of each of the four aquifer units. The bottom of the top layer corresponds to the top of the upper confining unit where present; however, the confining unit generally is absent along the south shore of the North Fork and in some areas along the north shore. The bottom of the top layer along the south shore is set at $10 \mathrm{ft}$ below sea level or $1 \mathrm{ft}$ below the sea floor, whichever is deeper. In north-shore areas where the upper confining unit also is absent, an approximate contact between the moraine and underlying drift is extrapolated offshore and forms the bottom of the top layer. The confining units are 


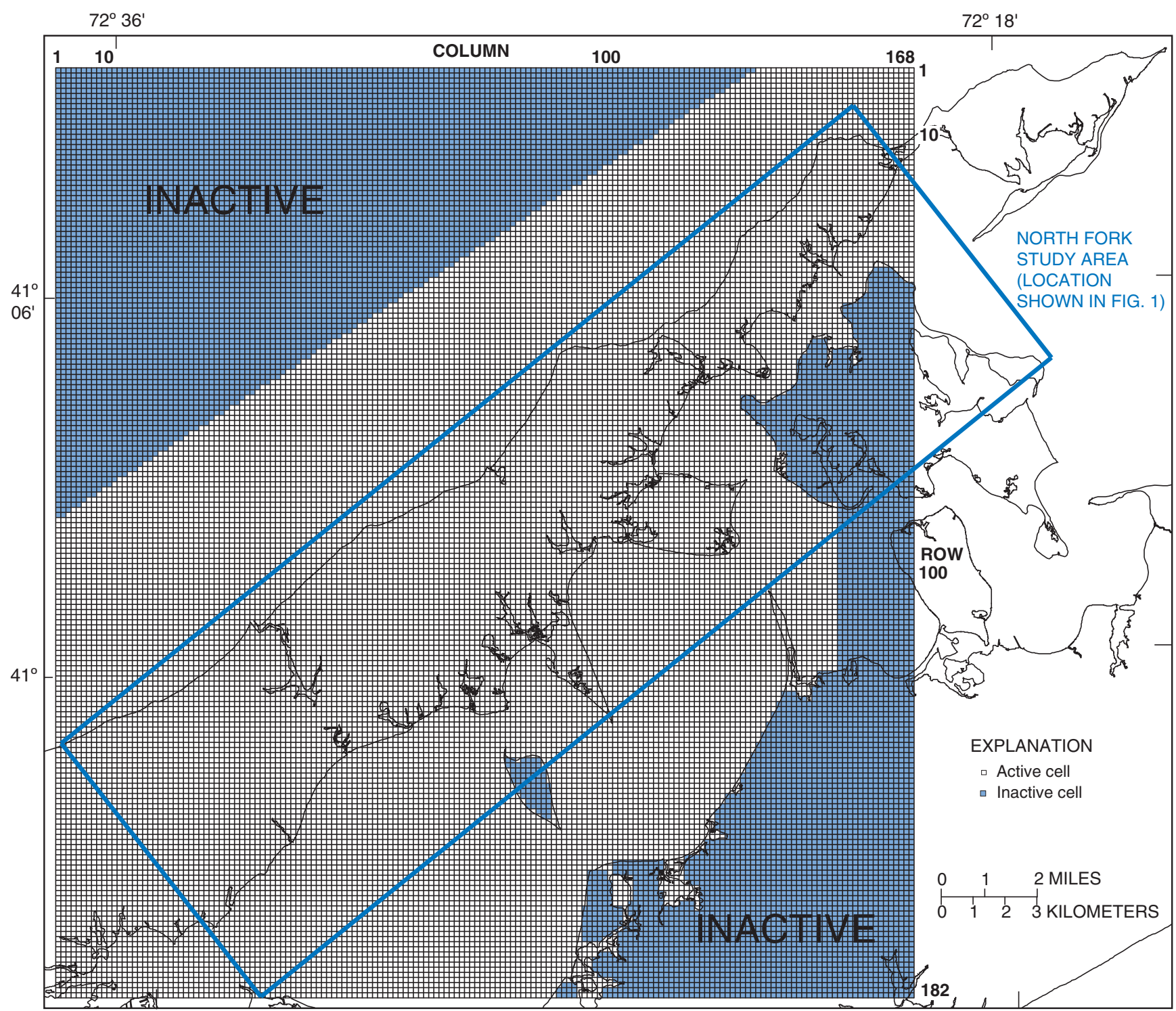

Figure 17. North Fork model grid, Suffolk County, N.Y., Suffolk County, N.Y. (Location is shown in fig. 1)

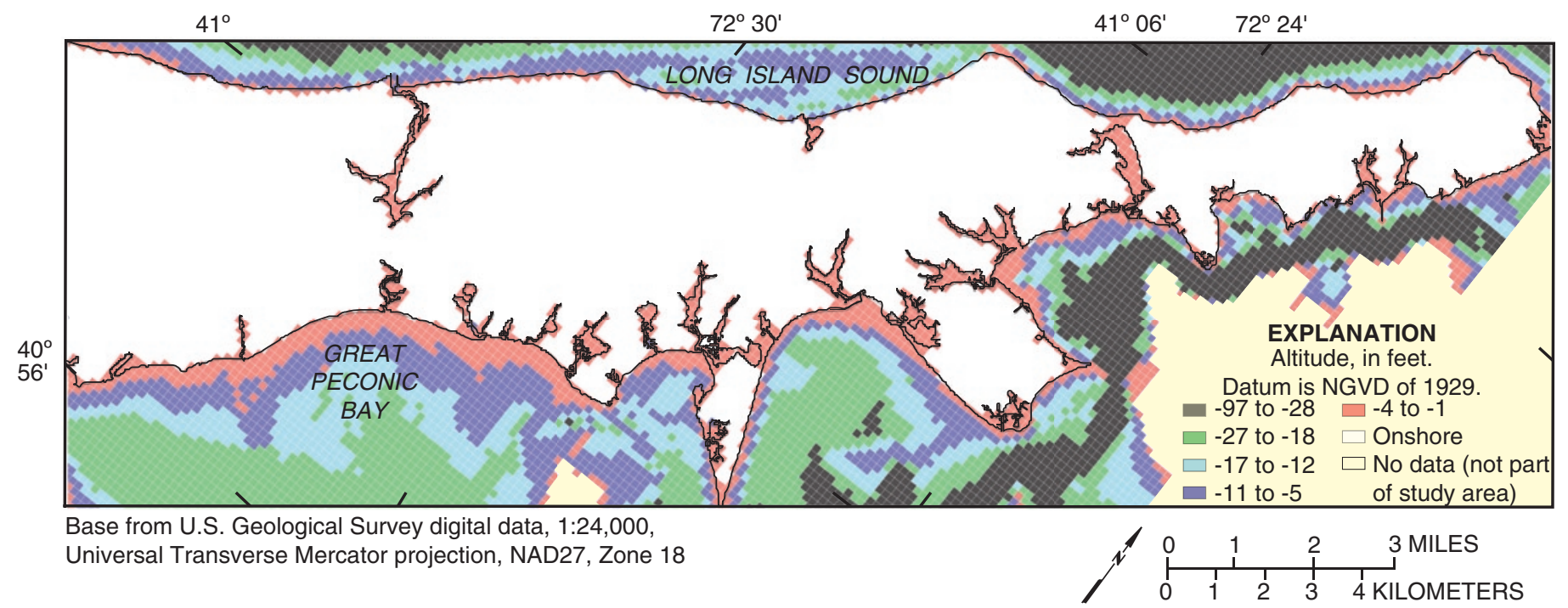

Figure 18. Sea floor bathymetry near North Fork, Suffolk County, N.Y. (Location is shown in fig. 1) 
not represented explicitly as model layers, but implicitly as restrictions in flow between the model layers, which represent only aquifers. The second layer represents upper glacial aquifer zone B; its bottom is the top of the lower confining unit. The third layer represents upper glacial aquifer zone $\mathrm{C}$; its bottom is the top of the Magothy aquifer. The fourth and lowest model layer represents the Magothy aquifer. No confining unit is present between the third and fourth layers. The bottom of the fourth layer is the top of the Raritan Clay.

A geographic information system (GIS) was used to interpolate the hydrogeologic surfaces developed by Schubert (2003) onto the grid and to assign hydraulic properties, boundary conditions, and initial conditions. Some flattening or "shelving" of the framework unit surfaces results from the 10 - $\mathrm{ft}$ contour interval of the source data, as seen in the vertical section in figure 5 , but the effect of this approximation on flow simulation is negligible.

\section{Boundary Conditions}

Model boundary conditions are depicted in a schematic section in figure 19. No-flow boundaries are specified at the lateral boundaries between active and inactive zones (fig. 17) and at the bottom of the model layer representing the Magothy aquifer (fig. 6A). The bottom of the Magothy aquifer is entirely salty and underlain in most places by a thick confining unit. The saline ground-water-flow system below the model's bottom boundary (Raritan Formation) was omitted because its effect on the movement of the freshwater-saltwater interface in response to freshwater pumping is assumed to be negligible.

The top model boundary in offshore areas is a constanthead boundary in a quasi-layer above the sea floor that represents shoreline underflow of freshwater to saline surface waters. The constant hydraulic-head value is specified to be the equivalent freshwater head $h_{f}$ of the column of saltwater overlying the sea floor, calculated as (Essaid, 1990):

where:

$$
\begin{aligned}
& h_{f}=z\left(\frac{\rho_{s}-\rho_{f}}{\rho_{f}}\right) \\
& h_{f}=\text { equivalent freshwater head [length] } \\
& z=\text { elevation of the sea floor relative to sea level } \\
& \text { [length] } \\
& \rho_{s}=\text { density of saltwater [mass/length }{ }^{3} \text { ] } \\
& \rho_{f}=\text { density of freshwater [mass/length }{ }^{3} \text { ] }
\end{aligned}
$$

During model calibration, the rate of saltwater flow into or out of the seabed is controlled by adjusting the vertical leakance through the sea floor. Freshwater is simulated to flow out of the sea floor, but not into it.

The top boundary of the model in onshore areas is a moveable, saturated/unsaturated boundary that represents the water table, to which a specified flux representing groundwater recharge is applied. Ground-water recharge is simulated by several zones representing recharge from precipitation and from public-supply return flow. The ground-water-recharge zones that were used to simulate 1994 steady-state recharge from precipitation are shown in figure 20A, which includes the locations of simulated streams, ponds, and lakes (discharge cells). Locations of 1994 public water-supply-district cells are shown in figure 20B; the recharge rates applied to each zone for 1994 steady-state conditions are summarized in figure $20 \mathrm{C}$ and table 4. Temporal variations in the applied rates of recharge from precipitation, and in the rates and extent of public-supply return flow, are discussed further on.

Streams in the upper model layer are simulated as constant-flux boundaries that represent base flow. Headdependent boundaries were not used because the streams contributed only a small percentage of flow out of corresponding model cells, making accurate simulation of base flow difficult. Measured base-flow values (described

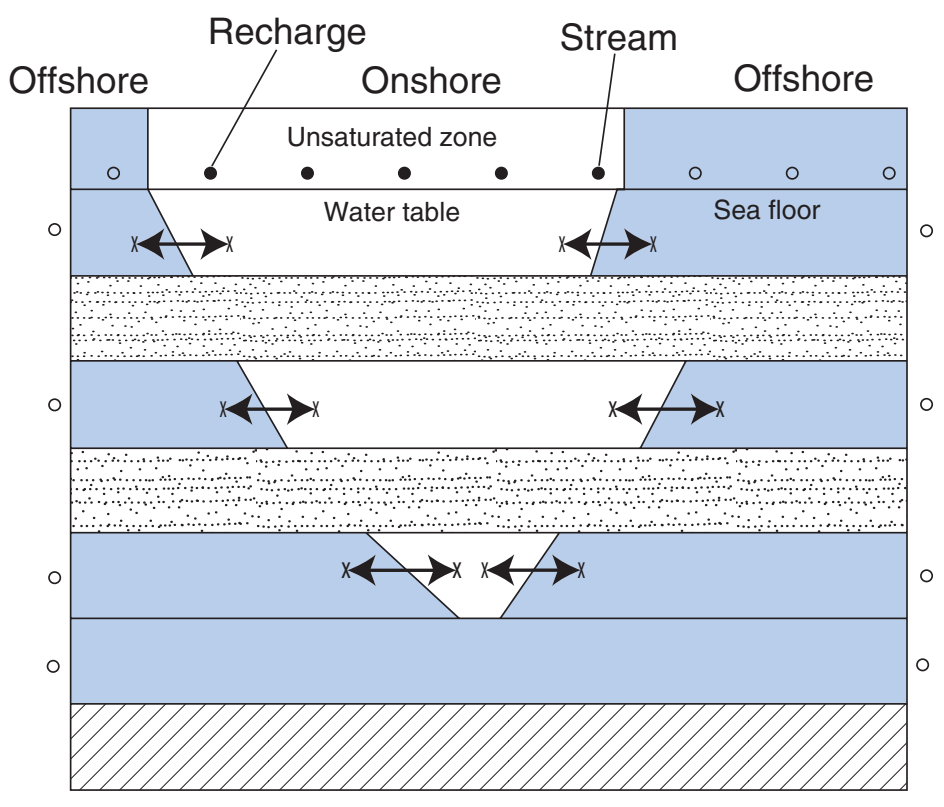

\section{EXPLANATION}

\section{Seawater}

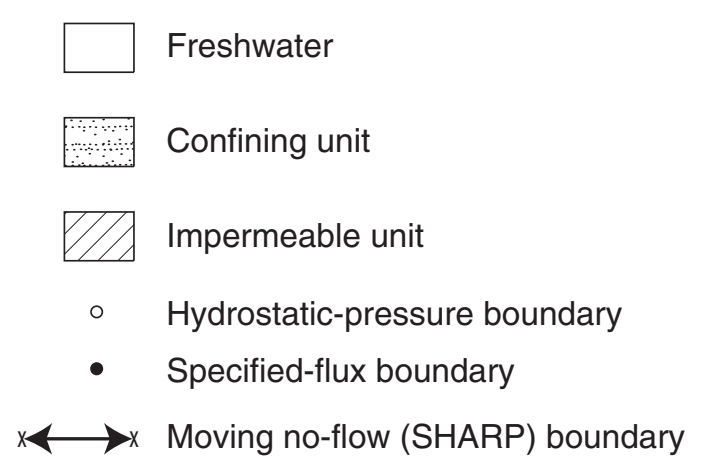

Figure 19. Conceptual diagram showing boundary conditions of the North Fork Model, Suffolk County, N.Y. 
A. Precipitation zones and locations of freshwater bodies

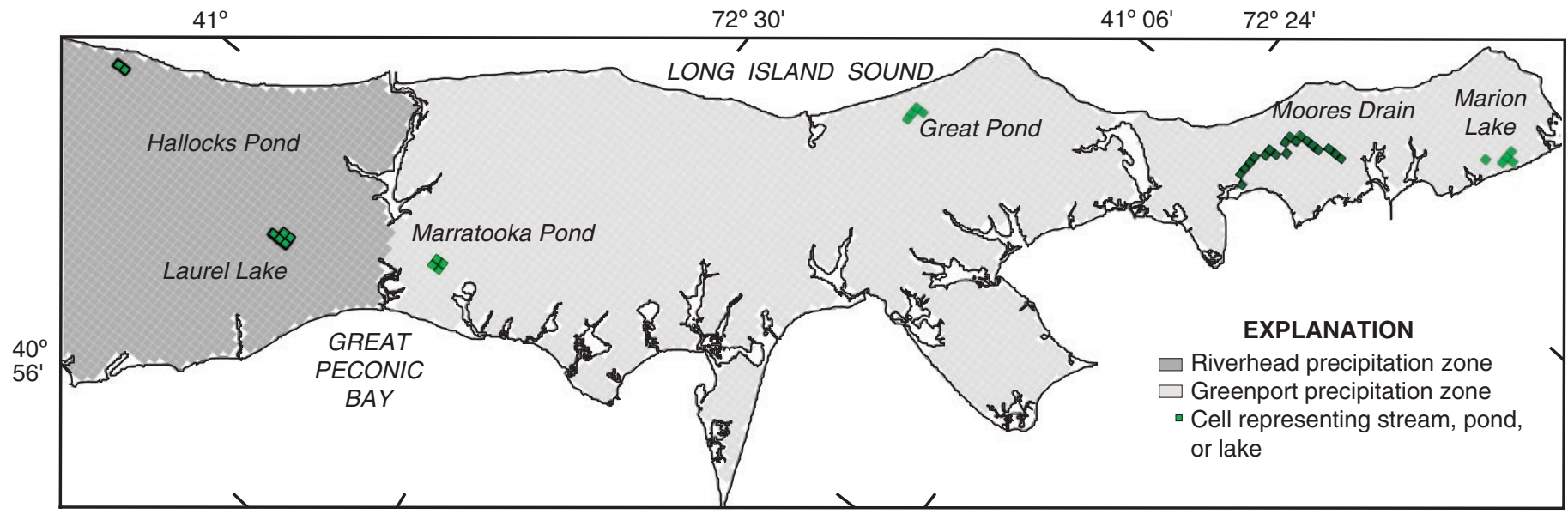

B. Public water-supply districts (unsewered areas)

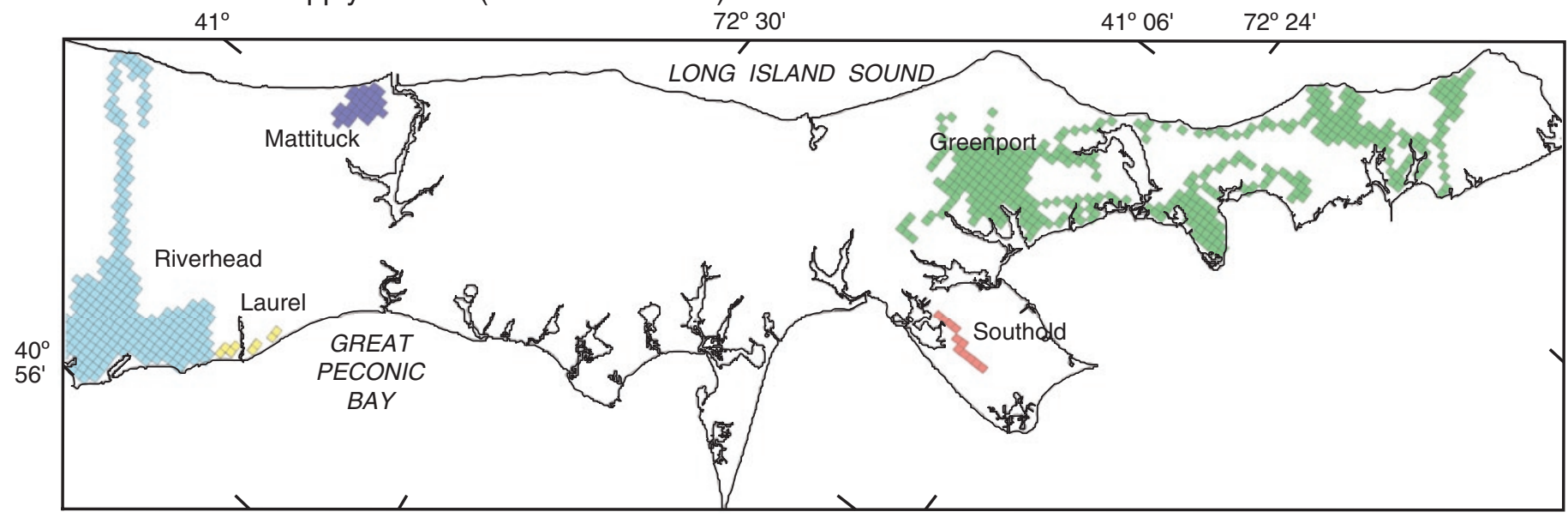

C. Ground-water recharge rates

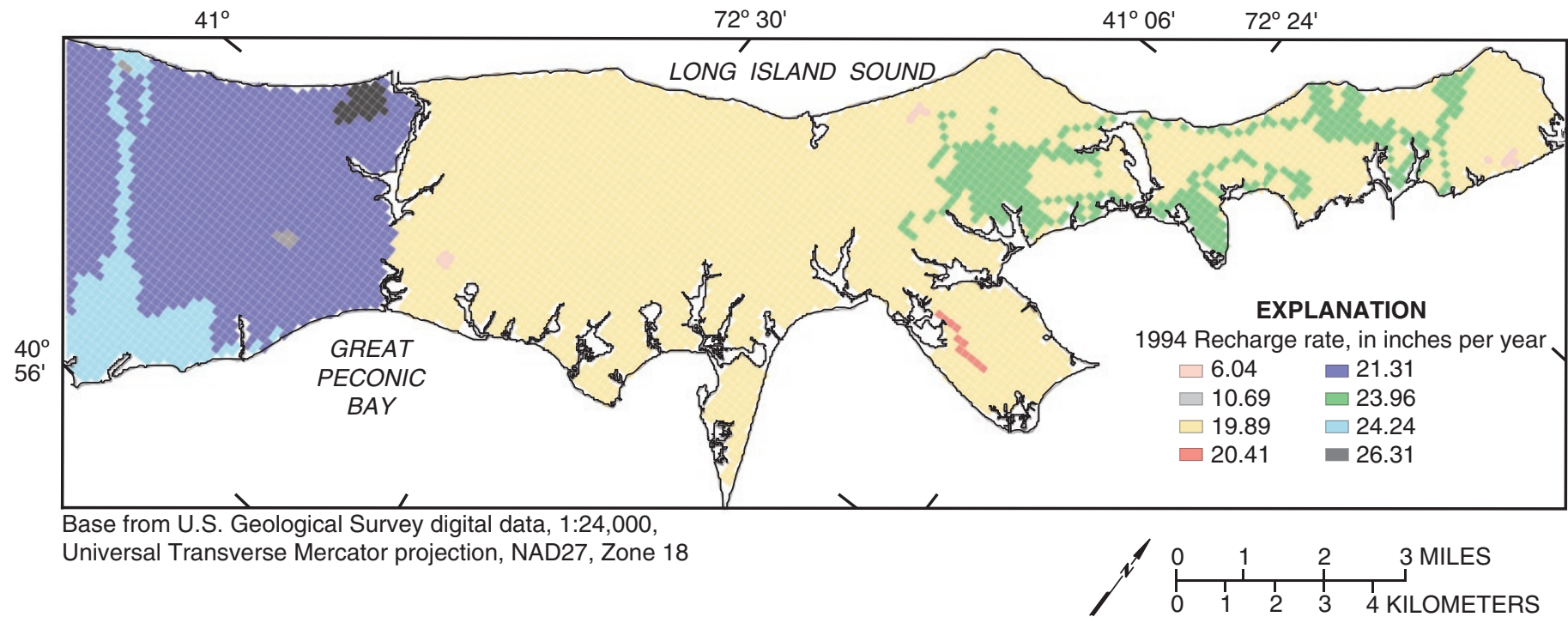

Figure 20. Locations of recharge zones, public water-supply districts, freshwater bodies, and recharge rates used for 1994 steady-state simulations in North Fork model, Suffolk County, N.Y.: A. Recharge zones and locations of freshwater bodies. B. Public water-supply districts. C. Ground-water-recharge rates. (Location is shown in fig. 1) 
Table 4. Simulated 1994 ground-water-recharge rates for North Fork model, Suffolk County, N.Y

[Values are in inches. Locations are shown in fig. 20.]

\begin{tabular}{lccc}
\hline Simulated zone & $\begin{array}{c}\text { Recharge } \\
\text { from } \\
\text { precipitation }\end{array}$ & $\begin{array}{c}\text { Public- } \\
\text { supply } \\
\text { return } \\
\text { flow }\end{array}$ & $\begin{array}{c}\text { Total } \\
\text { ground- } \\
\text { water } \\
\text { recharge }\end{array}$ \\
\hline Riverhead & 21.31 & 0 & 21.31 \\
Ponds & 10.69 & 0 & 10.69 \\
Riverhead/Laurel districts & 21.31 & 2.93 & 24.24 \\
Mattituck district & 21.31 & 5.00 & 26.31 \\
Greenport & 19.89 & 0 & 19.89 \\
Ponds & 6.04 & 0 & 6.04 \\
Greenport district & 19.89 & 4.07 & 23.96 \\
Great Hog district & 19.89 & 0.52 & 20.41 \\
\hline
\end{tabular}

previously) were distributed evenly among the model cells that contain the freshwater reach of each stream (fig. 20C) and were assumed to represent long-term conditions. Flow-through conditions at ponds and lakes were represented by increased hydraulic conductivity and storage values at corresponding model cells.

The lateral boundary along the onshore part of the western model boundary (column 1 of the model grid, fig. 17) is simulated as a constant-head boundary that hydraulically connects all four model layers to the flow system of the main body of Long Island. Constant-head values specified along this western upgradient boundary were interpolated from the recent water-table map of Schubert (1998).

Ground-water discharge to public-supply and miscellaneous wells was simulated as a constant-flux boundary at the model cell containing the screen of each well; the discharge of wells for which the screen penetrated multiple cells was distributed among those cells according to their percentage of total screen length. Locations of shallow public-supply wells (screened less than $45 \mathrm{ft}$ below sea level) are shown in figure 21A; locations of deep public-supply wells (screened $45 \mathrm{ft}$ or more below sea level) are shown in figure 21B. Discharge to wells pumped for irrigation was simulated as a specified-flux boundary at the water-table-aquifer cell at the centroid of each agricultural parcel; locations of 1994 agricultural parcels and points of withdrawal, analogous to wells, are shown in figure 21C. A map depicting agriculturalparcel location and size in 1999 was also available and shows only small changes from 1994.

\section{Model Calibration}

The North Fork model was calibrated through a quasisteady-state simulation of 1994 average-annual conditions; the results were then statistically compared with measured water levels and freshwater-saltwater interface positions that were assumed to match long-term equilibrium conditions. The water-level measurements used in the comparison were made in March-April 1994, and the interface positions were estimated by Schubert and others (2003) from data collected between about World War II and 2000. Locations of most of the observation wells used for water-level measurement are shown in figure 22A (some observation wells used for water-level measurement are not shown in the mapped area); locations of those used for interface-depth measurement are shown in figure 22B. Several other deep wells in the Town of Riverhead were also evaluated (fig. 22C; this western area is of secondary importance, however, because the simulation is constrained by nearby specified-head boundary conditions.

Values of horizontal hydraulic conductivity and vertical leakance between units were calibrated to minimize the difference between vertical hydraulic gradients measured at six paired observation wells and those simulated from 1994 average annual conditions. Observed (March-April 1994) and simulated water levels and gradients at these wells are summarized in table 5 .

Horizontal hydraulic conductivity values and vertical leakance values were calibrated to approach a target value of the mean residual and minimum root mean square error (RMSE) of the differences between measured and simulated values of head and interface elevation. The target mean residual used for water levels was the mean difference between three local mean sea-level datums and the National Geodetic Vertical Datum (NGVD) of 1929 , because reported water levels are calculated with reference to NVGD of 1929. The local mean sea-level datums at three sites on the North Fork and the corresponding mean are as follows:

$\begin{array}{ll}\text { Port Jefferson } & 0.53 \mathrm{ft} \\ \text { Threemile Harbor } & 0.48 \mathrm{ft} \\ \text { South Jamesport } & 0.32 \mathrm{ft} \\ \text { Mean } & 0.45 \mathrm{ft}\end{array}$

The target mean residual for interface positions was assigned a value of zero. The accuracy of these statistics is limited, however, by a discretization (offset) error between the location of each field measurement and the center of the corresponding model cell for which simulated results are evaluated.

Residual mean, M, is calculated as:

$$
M=\left(\sum_{i=1}^{n} X m_{i}-X s_{i}\right) / n
$$

where:

$X m=$ measured value

$X s$ = simulated value

$n$ = number of comparisons

RMSE is calculated as:

$R M S E=\left[\left(\sum_{i=1}^{n}\left(X m_{i}-X s_{i}\right)^{2}\right) / n\right]^{-0.5}$ 
A. Public- and commercial-supply wells screened less than 45 feet below sea level

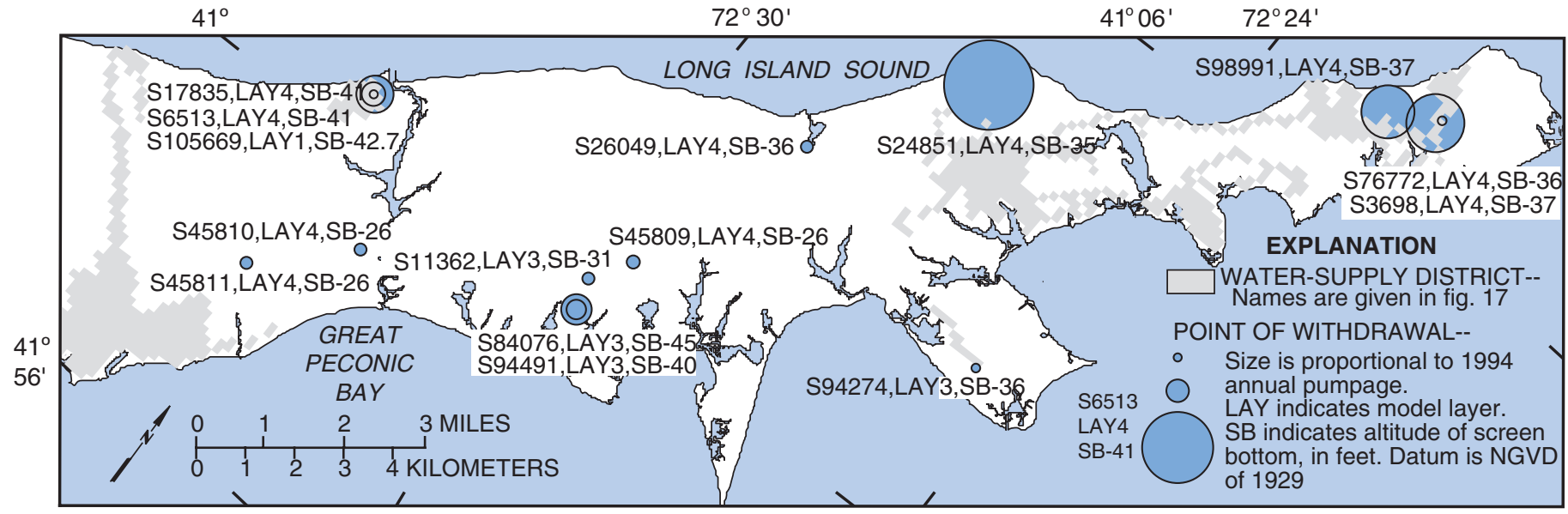

B. Public- and commercial-supply wells screened 45 feet or more below sea level

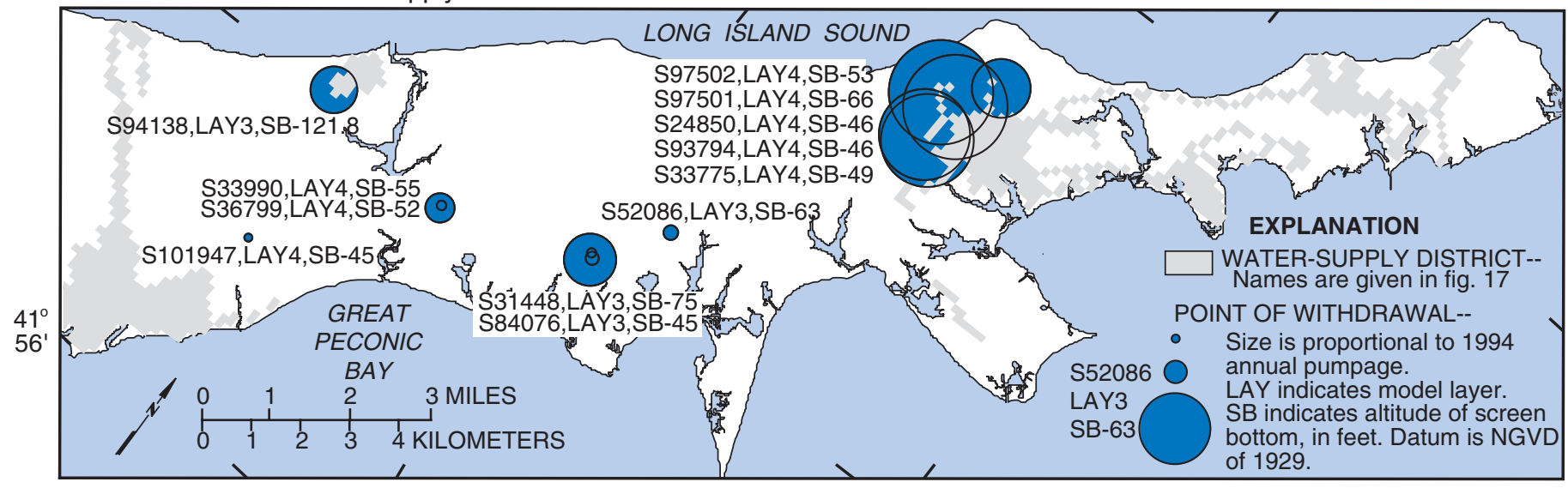

C. Agricultural parcels and irrigation wells.

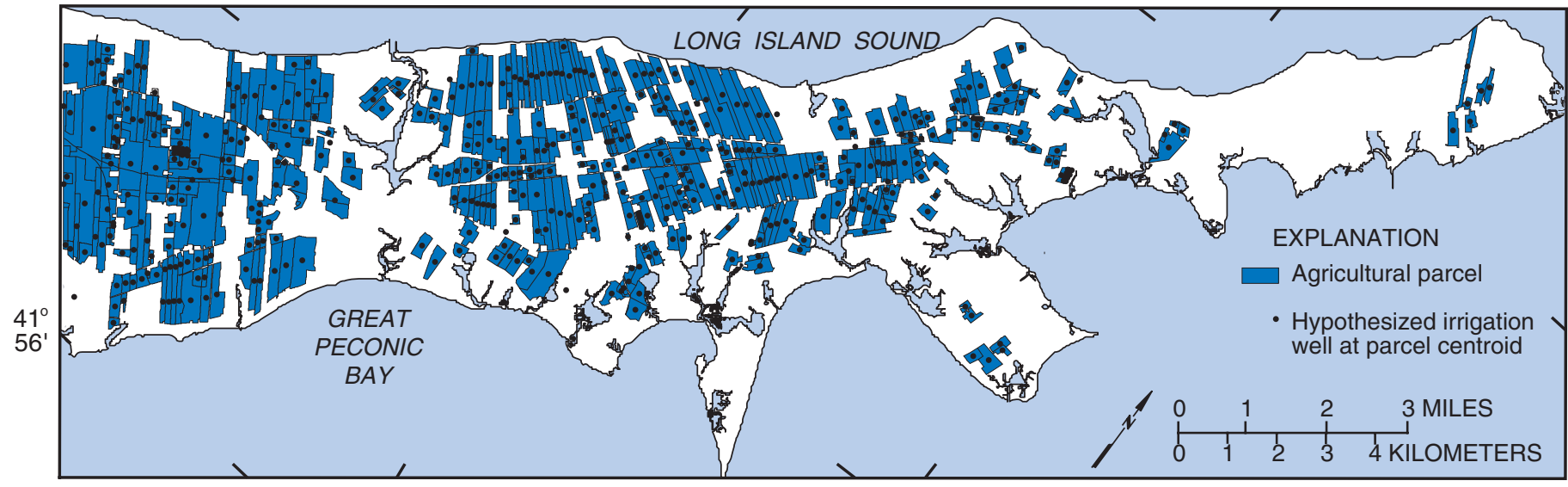

Base from U.S. Geological Survey digital data, 1:24,000,

Universal Transverse Mercator projection, NAD27, Zone 18

Figure 21. Locations of public-supply and commercial-supply wells in 1994 in North Fork model, Suffolk County, N.Y.: A. Public- and commercial-supply wells screened less than 45 feet below sea level. B. Public- and commercial-supply wells screened 45 feet or more below sea level. C. Agricultural parcels and irrigation wells. (Location is shown in fig. 1) 
A. Wells used for water-level measurement

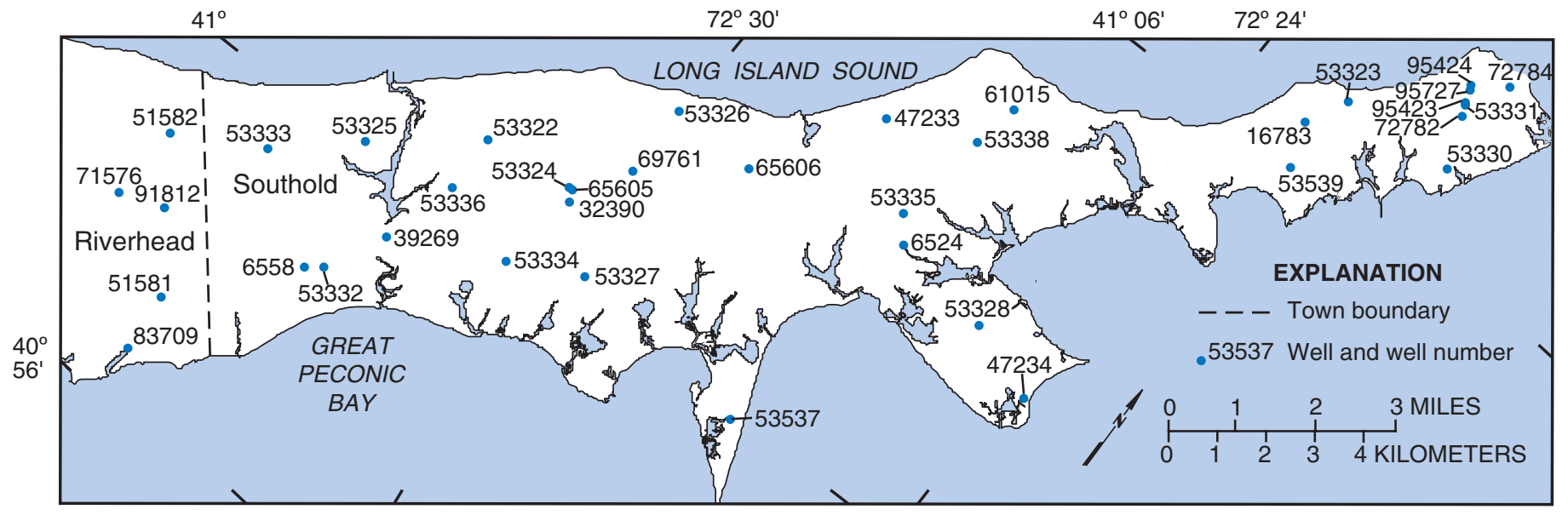

B. Wells used to estimate position of freshwater-saltwater interface

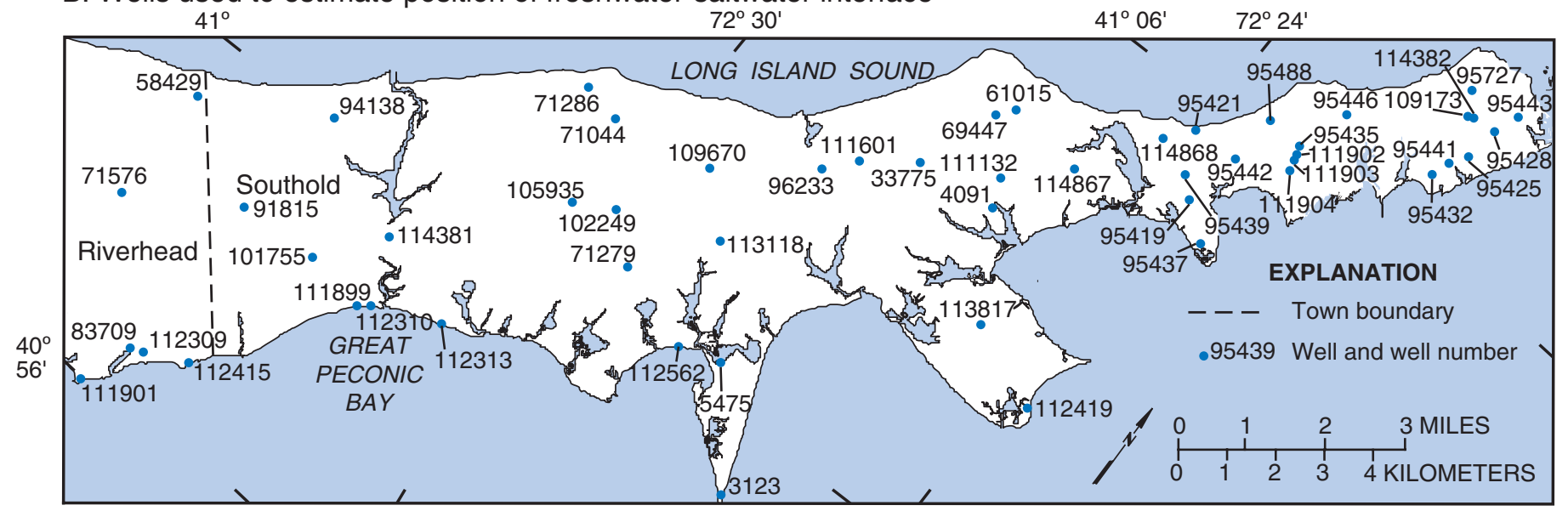

C. Secondary wells near western extent of grid

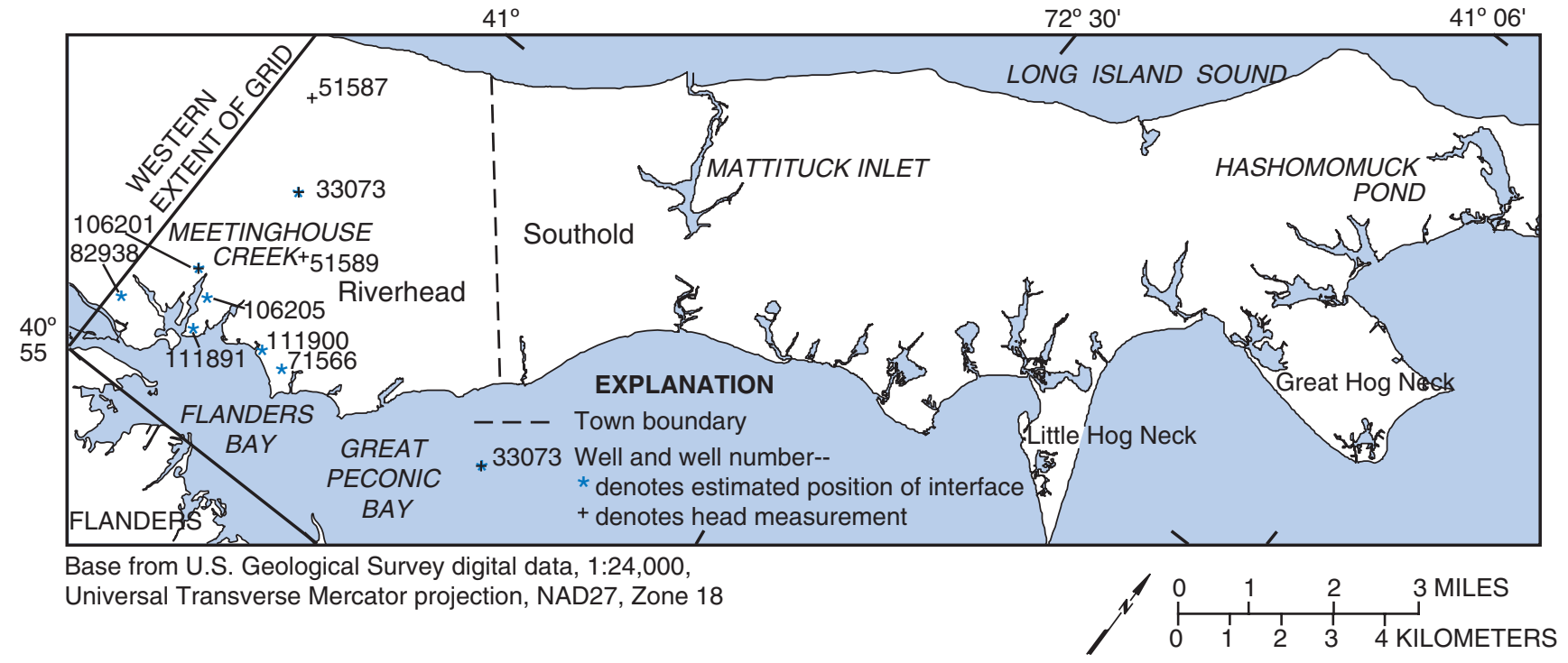

Figure 22. Locations of observation wells used in calibration of North Fork model, Suffolk County, N.Y.: A. Wells used for water-level measurement. B. Wells used for freshwater-saltwater-interface measurement. C. Secondary wells near western extent of grid. (Location is shown in fig. 1) 
Table 5. Measured (March-April 1994) and simulated water levels and hydraulic gradients at six well pairs in North Fork study area, Suffolk County, N.Y.

[Water levels are in feet above sea level. Well locations are shown in fig. 22. Well numbers are assigned by New York State Department of Environmental Conservation; prefix S denoting Suffolk County is omitted.]

\begin{tabular}{|c|c|c|c|c|c|c|}
\hline \multirow{2}{*}{$\begin{array}{l}\text { Statistic } \\
\text { Upper well }\end{array}$} & \multicolumn{6}{|c|}{ Well number } \\
\hline & 91813 & 53331 & 71045 & 65605 & 95424 & 83792 \\
\hline Measured water level & 10.0 & 4.0 & 7.1 & 7.8 & 3.6 & 1.8 \\
\hline Simulated water level & 9.7 & 3.5 & 8.3 & 8.8 & 3.2 & 2.8 \\
\hline Lower well & 71576 & 95423 & 69761 & 53324 & 95727 & 83709 \\
\hline Measured water level & 9.5 & 4.1 & 6.9 & 7.7 & 2.4 & 4.7 \\
\hline Simulated water level & 9.1 & 3.5 & 8.3 & 8.8 & 3.1 & 5.1 \\
\hline \multicolumn{7}{|c|}{ Relation between water levels in upper and lower wells } \\
\hline Difference between measured values & 0.5 & -0.1 & 0.2 & 0.1 & 1.2 & -2.9 \\
\hline Difference between simulated values & 0.6 & 0 & 0 & 0 & 0.1 & -2.3 \\
\hline Measured gradient between upper and lower wells & 0.00198 & -0.00216 & 0.0022 & 0.0066 & 0.0176 & -0.0209 \\
\hline Simulated gradient between upper and lower wells & 0.00194 & 0 & 0.00110 & 0 & -0.0001 & -0.0049 \\
\hline Ratio of simulated to measured gradient & 0.979 & 0 & 0.498 & 0 & -0.005 & 0.238 \\
\hline
\end{tabular}

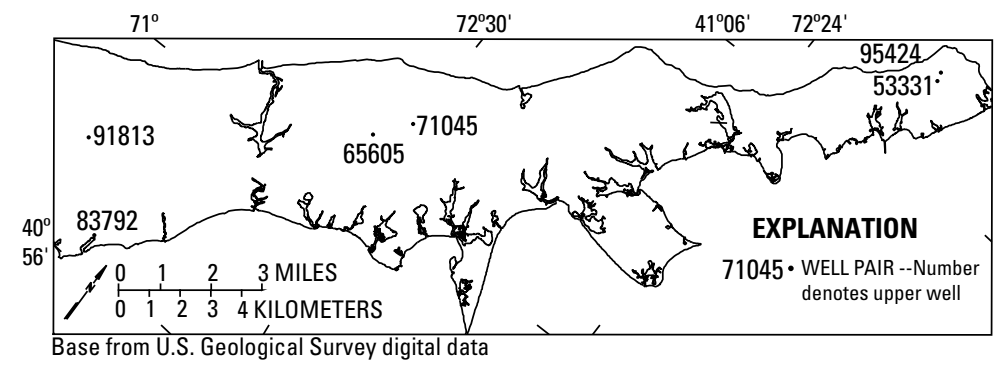

WELL LOCATIONS

Table 6. Calibration statistics on ground-water levels and saltwater interface for hydrogeologic units in North Fork model [Values are in feet. $M$, residual mean; RMSE, root mean square error; n.a., not applicable]

\begin{tabular}{lrrr}
\hline \multicolumn{1}{c}{ Model layer } & $M$ & RMSE & $\begin{array}{c}\text { Population } \\
(n)\end{array}$ \\
\hline Ground-water levels & & & \\
Upper glacial zone A Outwash & 0.44 & 0.93 & 27 \\
Upper glacial zone A Moraine & 0.59 & 0.81 & 6 \\
Upper glacial zone B & 0.30 & 0.79 & 10 \\
Upper glacial zone C & 0.54 & 0.54 & 2 \\
Magothy & 0.64 & 0.89 & 3 \\
Total & 0.44 & 0.88 & 48 \\
Interface elevation below sea level & & \\
Upper glacial zone A & 18.44 & 31.23 & 16 \\
Upper glacial zone B & 27.10 & 36.16 & 23 \\
Upper glacial zone C & -22.39 & 80.46 & 23 \\
Total & 6.51 & n.a. & 62 \\
\hline
\end{tabular}


where variables are as stated above. Populations of head values and interface values, and subsets thereof, were summed. Head-data subsets were separated by aquifer according to the model layer or water-table zone (table 6 ) in which observation wells were screened, and interface-data subsets were separated according to the presence or absence of a confining layer above the interface. Final modeled hydraulic conductivity values that obtained the best calibration statistics are summarized in table 2; these values are generally consistent with previously reported values (see Schubert and others, 2003). Horizontal conductivity of the Magothy aquifer required a slight decrease from the previously reported values to obtain the best calibration statistic. Horizontal hydraulic conductivity of top-layer cells that represent major freshwater surface-water bodies was increased to $50,000 \mathrm{ft} / \mathrm{d}$ to provide a flow-through condition, wherein water flowing through the surface-water body becomes part of the simulated mass balance of the model cell.

Model storage parameters (table 7) were tested and adjusted throughout the study. The final value for unconfined freshwater specific storativity was $0.15 \mathrm{ft}^{-1}$, and that for confined storativity was $0.00002 \mathrm{ft}^{-1}$. Storativity of top-layer cells containing major freshwater surface-water bodies was increased, from $0.15 \mathrm{ft}^{-1}$ to $1.0 \mathrm{ft}^{-1}$ to represent the effect of the fully saturated water body. The small value for confined aquifers results from the lack of dewatering of the porous aquifer medium. None of the aquifers are fully confined and, therefore, deep cones of depression do not develop in response to pumping.

Additional model parameters that were tested and adjusted throughout the study are included in table 7 . These values were optimized for computer efficiency in conjunction with the head and interface adjustments described above.

Results of the transient-state simulation of 1941-2005 seasonal conditions also were compared with measured values. The model-generated and historical water levels at a typical observation well with an extensive record (S16764, redeveloped as S53324; fig. 22A) are plotted as a time series in figure 23A. The simulated freshwater-saltwater interface (fig. 23B) shows seasonal fluctuations and moves upward during 1961-66 - first as a result of agricultural pumping, then in response to the 1962-66 drought. After the drought, it levels off and approaches a steady state until about 1995, when it moves upward about $5 \mathrm{ft}$ in response to an increase in publicsupply pumpage. Figures $23 \mathrm{~A}-\mathrm{B}$ are representative of about 20 other graphs that were generated for the wells in the area for which long-term records are available.

\section{Sensitivity Analysis}

A sensitivity analysis defines model uncertainty in aquifer properties, hydrologic stresses, boundary conditions, and any other factors that may affect model results by varying their values individually and observing the changes in model results. The sensitivity analysis in this study was
Table 7. Parameter values used in North Fork model

[ft, foot; $\mathrm{lb} / \mathrm{ft}^{3}$ pounds per cubic foot; $\mathrm{lb} /(\mathrm{ft} \bullet \mathrm{s})$, pound per foot second ]

\begin{tabular}{ll}
\hline \multicolumn{1}{c}{ Parameter } & \multicolumn{1}{c}{ Value } \\
\hline Specific storativity (unconfined) & $0.15 / \mathrm{ft}$ \\
Specific storativity (confined) & $1.0 \times 10^{-6} / \mathrm{ft}$ \\
Specific weight, freshwater & $62.41 \mathrm{lb} / \mathrm{ft}^{3}$ \\
Specific weight, saltwater & $63.60 \mathrm{lb} / \mathrm{ft}^{3}$ \\
Dynamic viscosity, freshwater & $2.09 \times 10^{-6} \mathrm{lb} /(\mathrm{ft} \bullet \mathrm{s})$ \\
Dynamic viscosity, saltwater & $2.09 \times 10^{-6} \mathrm{~b} /(\mathrm{ft} \bullet \mathrm{s})$ \\
SHARP 1 leakage method & restricted \\
SHARP convergence (iteration) & 0.02 \\
\hline${ }^{1}$ Essaid, 1990 &
\end{tabular}

used to test the effects of aquifer hydraulic conductivity, confining-unit leakance, and recharge and withdrawal rates on model heads and interface position. Several values for each of these parameters were tested; the values ranged from one-half to twice the calibrated value throughout the model. Figures 24A-B show the response of calibration statistics, as defined in a previous section, to changes in parameters based on multiplication factors (amount of parameter change). The model showed greater sensitivity to aquifer hydraulic conductivity than to confining-unit leakance. Increasing the total anisotropy (ratio of horizontal to vertical hydraulic conductivity) of the model, either by increasing the scalar conductivity values for a model layer or decreasing confining-layer leakance, produced a flattening effect whereby the maximum depth of freshwater rose, and the maximum offshore extent of freshwater increased. Boundary-condition placement was a moderating factor-an observation corroborated by Spitz (1998). Sensitivities to saltwater interface movement were also analyzed. Porosity strongly affected the rate of transient-state saltwater-interface movement.

\section{Steady-State Simulation Results}

A model-generated freshwater budget of each aquifer for 1994 average annual conditions on the North Fork is given in table 8 . The lack of absolute balance was caused by use of a moderately loose convergence criterion and also inaccuracy resulting from the SHARP mixing method (discussed in a previous section). About 90 percent of the freshwater that enters the flow system represents recharge from precipitation and public-supply return flow; the remaining 10 percent enters as ground-water flow from the main body of Long Island. About half of the total recharge remains in the modeled upper glacial aquifer zone $\mathrm{A}$ and exits the system as shoreline discharge; another 40 percent reaches the upper glacial aquifer zone $\mathrm{B}$, and about 10 percent reaches the upper glacial aquifer zone C. Less than 1 percent of total recharge at the water table reaches the Magothy aquifer. 
A. Measured and simulated water levels

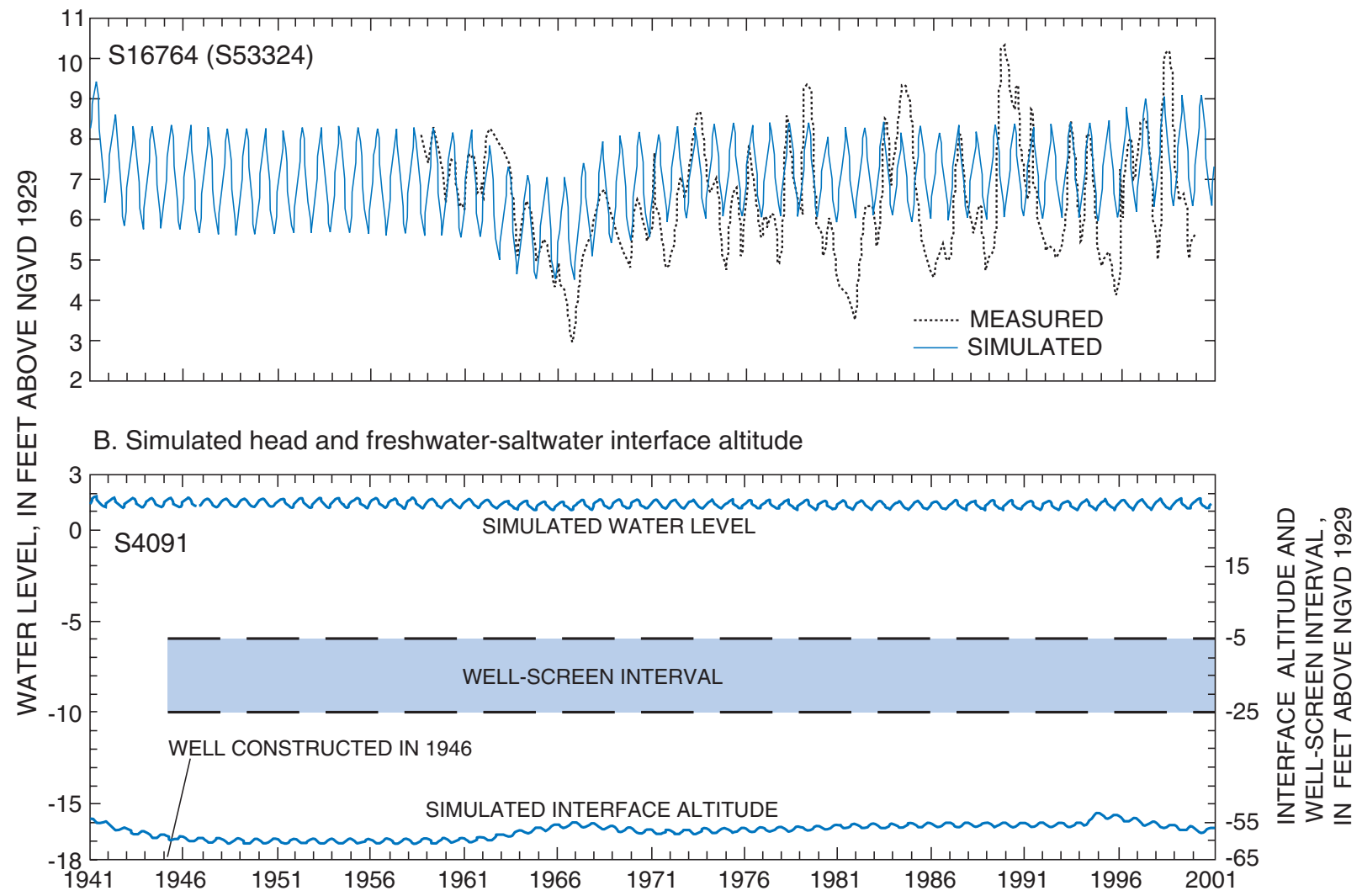

Figure 23. Measured and simulated ground-water level and freshwater-saltwater interface depths: A. Measured and simulated water levels at well S16764. B. Simulated head and interface depth at well S4091. (Well location shown in figure 22A)

A. Mean residual

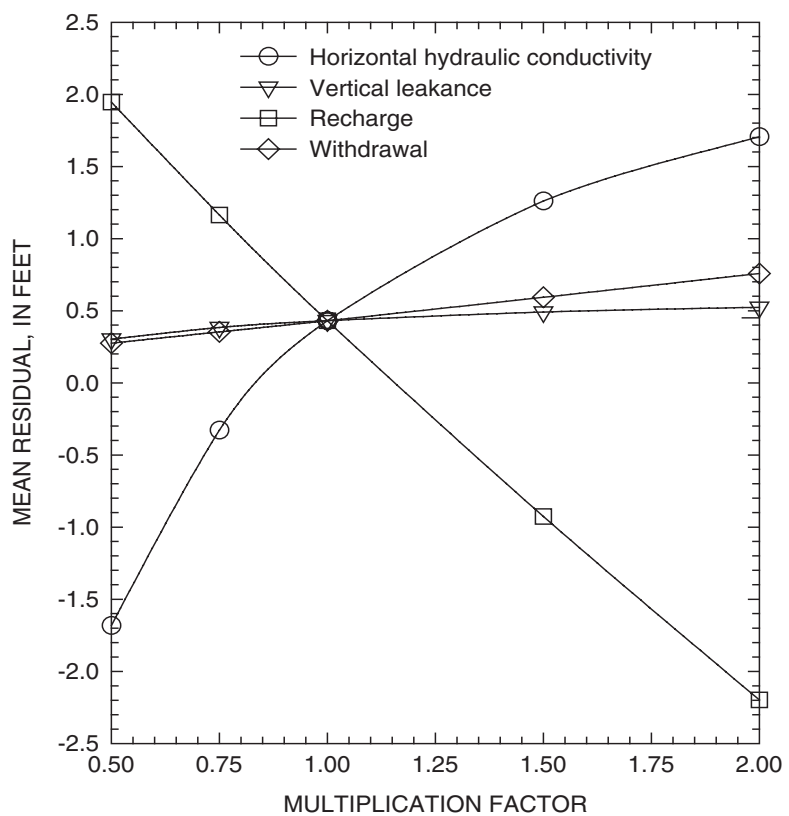

B. Root mean square error

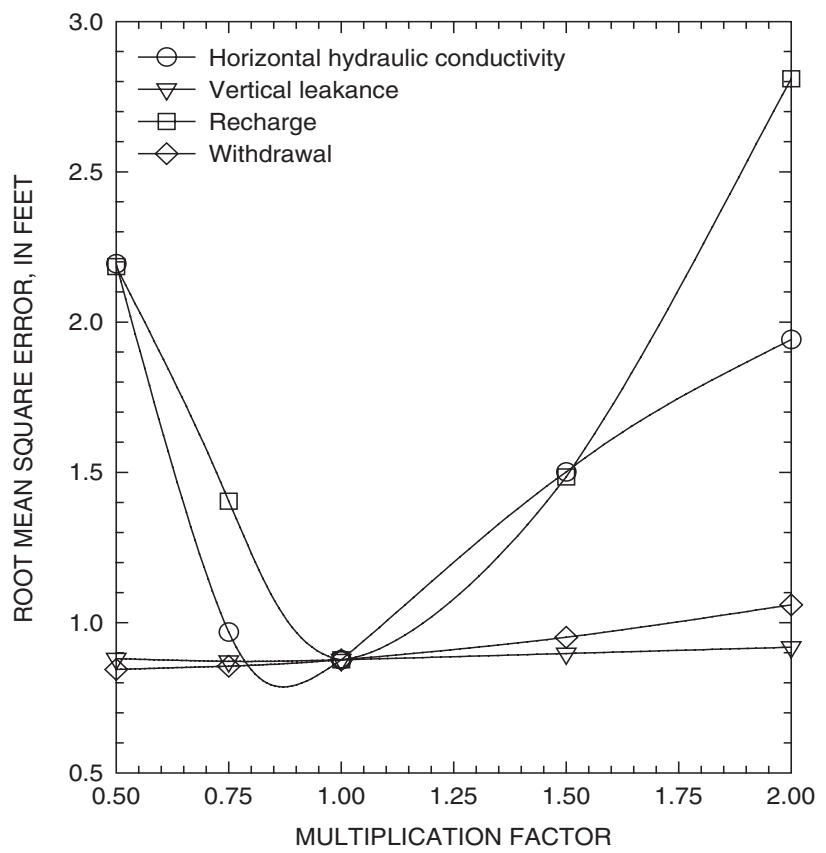

Figure 24. Sensitivity of simulated hydraulic head to variations in the values of selected parameters in the North Fork model: A. Mean residual. B. Root mean square error. 

North Fork of Long Island, New York

Table 8. Model-generated fresh-ground-water budget for 1994 average annual conditions

\begin{tabular}{|c|c|c|c|}
\hline $\begin{array}{l}\text { Aquifer and budget } \\
\text { component }\end{array}$ & $\begin{array}{l}\text { Budget value } \\
\text { (cubic feet per second) }\end{array}$ & $\begin{array}{l}\text { Aquifer and budget } \\
\text { component }\end{array}$ & $\begin{array}{l}\text { Budget value } \\
\text { (cubic feet per second) }\end{array}$ \\
\hline Upper glacial aquifer zone $A$ & & Upper glacial aquifer zone $C$ & \\
\hline INFLOW & & INFLOW & \\
\hline Recharge & 75.23 & Constant head & 2.26 \\
\hline Constant head & 0.56 & Leakage through top & 7.25 \\
\hline Leakage through bottom & 17.61 & Leakage through bottom & 4.60 \\
\hline OUTFLOW & & OUTFLOW & \\
\hline Pumpage & 3.14 & Pumpage & 0 \\
\hline Constant head & 0.98 & Constant head & 1.54 \\
\hline Leakage through top & 53.73 & Leakage through top & 12.60 \\
\hline Leakage through bottom & 37.32 & Leakage through bottom & 0.35 \\
\hline Upper glacial aquifer zone $B$ & & Magothy aquifer & \\
\hline INFLOW & & INFLOW & \\
\hline Constant head & 0.52 & Constant head & 5.59 \\
\hline Leakage through top & 34.65 & Leakage through top & 0.35 \\
\hline Leakage through bottom & 5.90 & & \\
\hline OUTFLOW & & OUTFLOW & \\
\hline Pumpage & 0.21 & Pumpage & 0 \\
\hline Constant head & 0.73 & Constant head & 0 \\
\hline Leakage through top & 34.07 & Leakage through top & 5.61 \\
\hline Leakage through bottom & 7.97 & & \\
\hline
\end{tabular}

The simulated water-table altitude under 1994 average annual conditions on the North Fork is depicted in figure $25 \mathrm{~A}$, and can be compared with figure 15 , which depicts the measured altitudes. The simulated head values reach a peak altitude of $12 \mathrm{ft}$ in the main Long Island flow system, $9 \mathrm{ft}$ in the Cutchogue system, and $6 \mathrm{ft}$ in the Greenport system. Small water-table mounds with altitudes of less than $3 \mathrm{ft}$ are indicated on Little Hog Neck and Great Hog Neck.

The position of the freshwater-saltwater interface in the upper glacial aquifer zone A under 1994 average annual conditions is shown in figure 25B. The interfaces occur in the band of cells that contain both freshwater and saltwater. The width of the band of mixed-water cells is a function of layer thickness, boundary conditions, and pumpage; it is narrowest in areas where the coastline is even rather than convoluted.

The all-freshwater part of the model can be separated conceptually at mixed-water cells into distinct lenses, or channels, that convey freshwater through a continuous sequence of model cells containing water that is either completely or partly fresh. The main Long Island/Cutchogue lens is the largest and extends from the main Long Island edge of the model eastward to the Cutchogue flow system east of Mattituck Inlet. The Little Hog Neck and Great Hog Neck lenses are separated from the main Long Island/Cutchogue lens by local embayments, and the Greenport lens is separated from the main Long Island/Cutchogue lens by Hashamomuck Pond. All of these lenses extend downward through the upper confining layer and may divide into sublenses in the Ronkonkoma drift layer.

The simulated potentiometric surface in the upper glacial aquifer zone B under 1994 average annual conditions is shown in figure 26A. The head configuration in zone B is similar to that of the water table (fig. 24A) except where fully salty cells appear in an inland area near Mattituck Inlet. The simulated position of the freshwater-saltwater interface is shown in figure 26B.

Flow lenses that originate in the upper glacial aquifer zone A divide into sublenses below the upper confining unit. The main Long Island/Cutchogue lens (fig. 25B) divides into main Long Island and Cutchogue sublenses that are separated by saltwater underlying the Mattituck Inlet. The Greenport lens (fig. 25B) divides into Greenport and East Marion sublenses that are separated by saltwater underlying several small embayments with the city of Greenport. The Little Hog Neck and Great Hog Neck lenses do not divide, and terminate in the Ronkonkoma drift layer. The East Marion sublens also terminates in the Ronkonkoma drift layer. The main Long Island and Greenport sublenses extend downward through the lower confining layer but do not divide in the bottom glacial layer. 
A. Simulated 1994 water levels in freshwater-flow system in upper glacial aquifer zone A

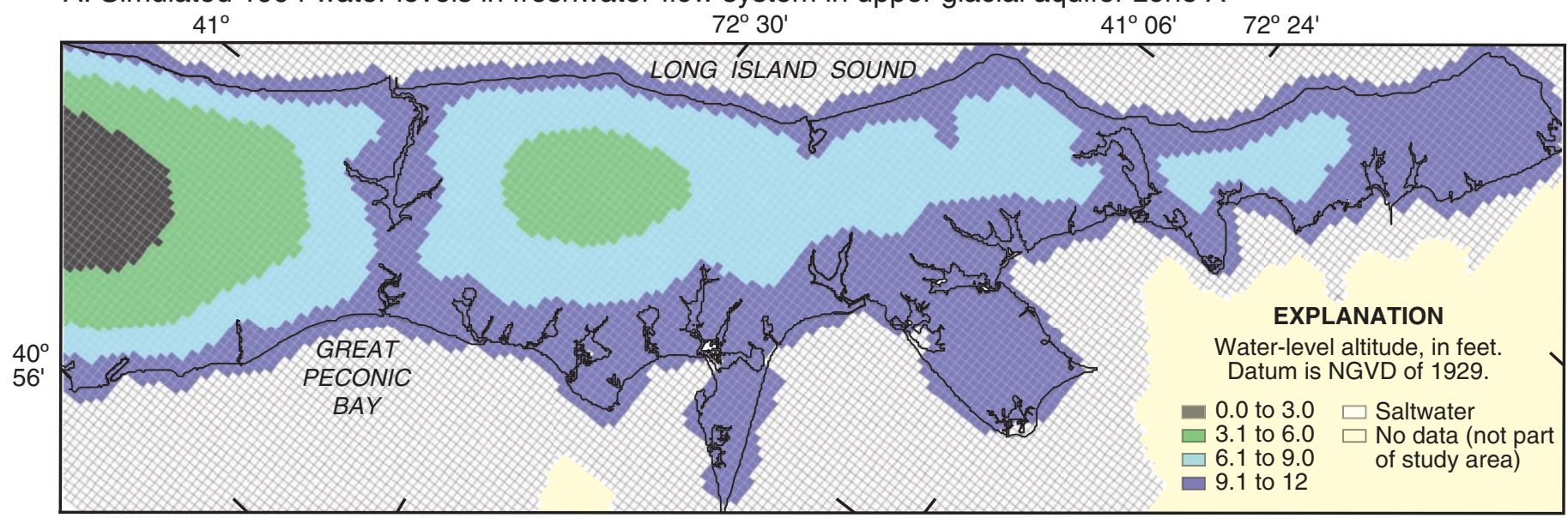

B. Simulated 1994 freshwater-saltwater interface position in upper glacial aquifer zone A

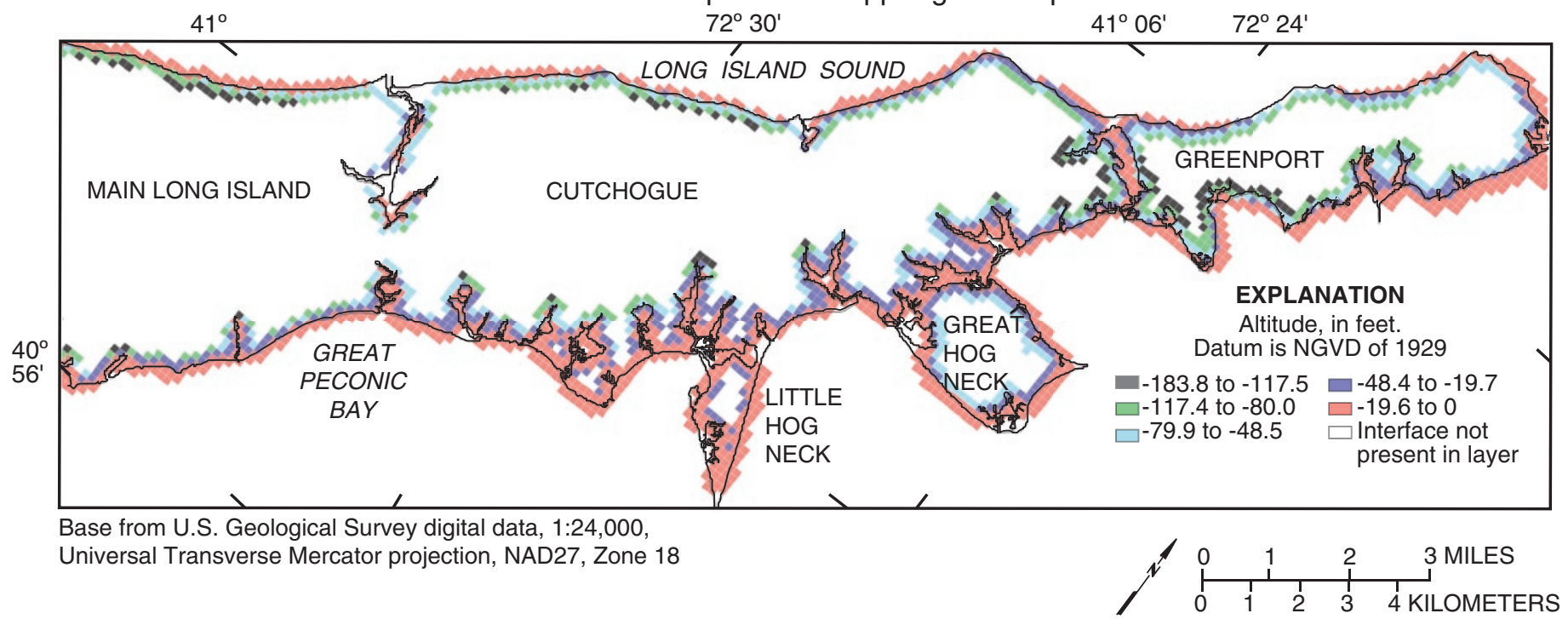

Figure 25. Simulated water-level and freshwater-saltwater interface position for the upper glacial aquifer zone A, 1994 average annual conditions on the North Fork, Suffolk County, N.Y.: A. Simulated 1994 water levels in freshwater-flow system. B. Simulated 1994 freshwater-saltwater interface position. (Location is shown in fig. 1) 
A. Simulated 1994 water levels in freshwater-flow system in upper glacial aquifer zone B

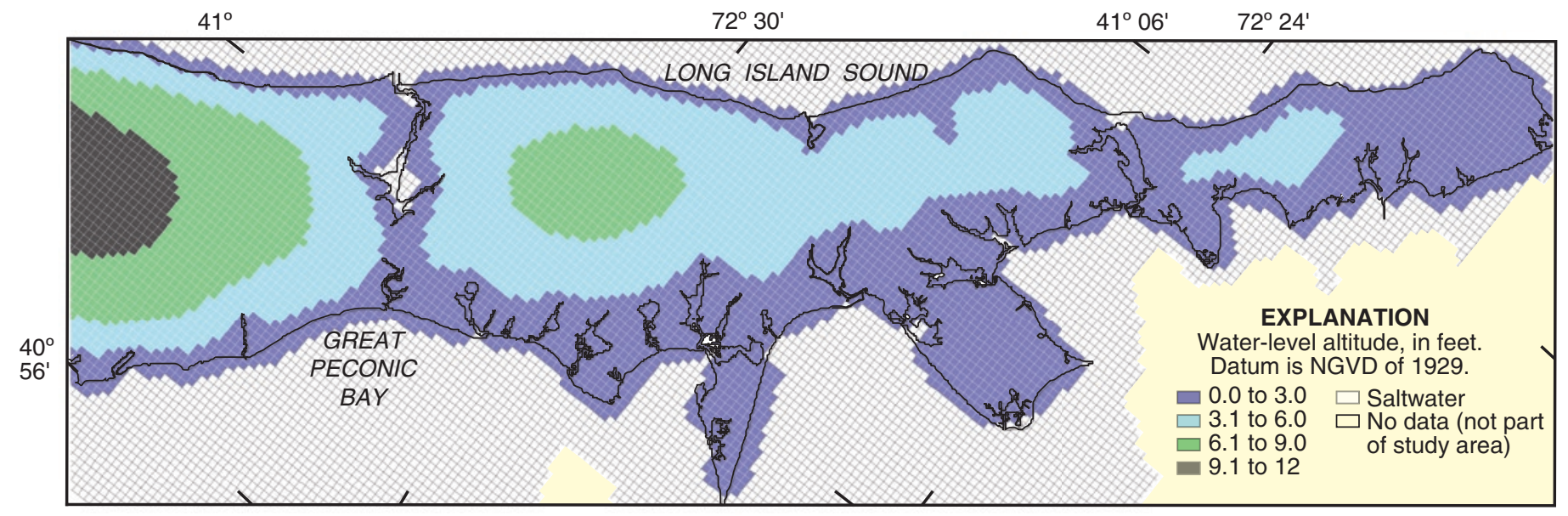

B. Simulated 1994 freshwater-saltwater interface position in upper glacial aquifer zone B

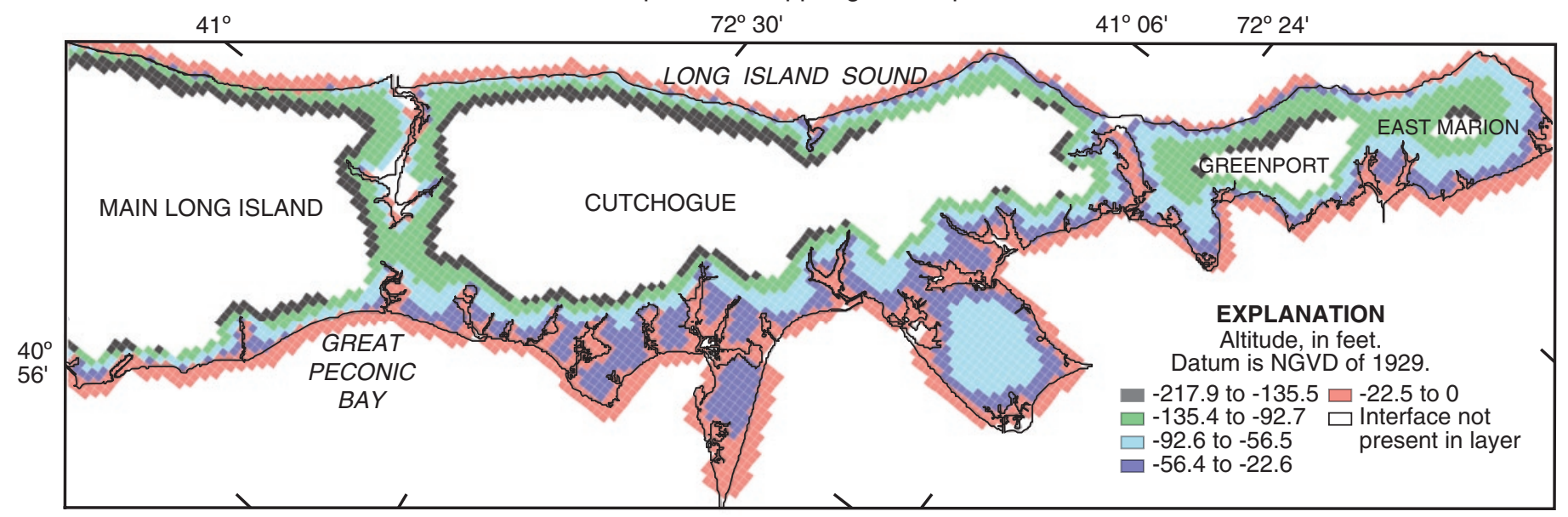

C. Simulated 1994 freshwater vertical gradient between upper glacial aquifer zones $A$ and $B$

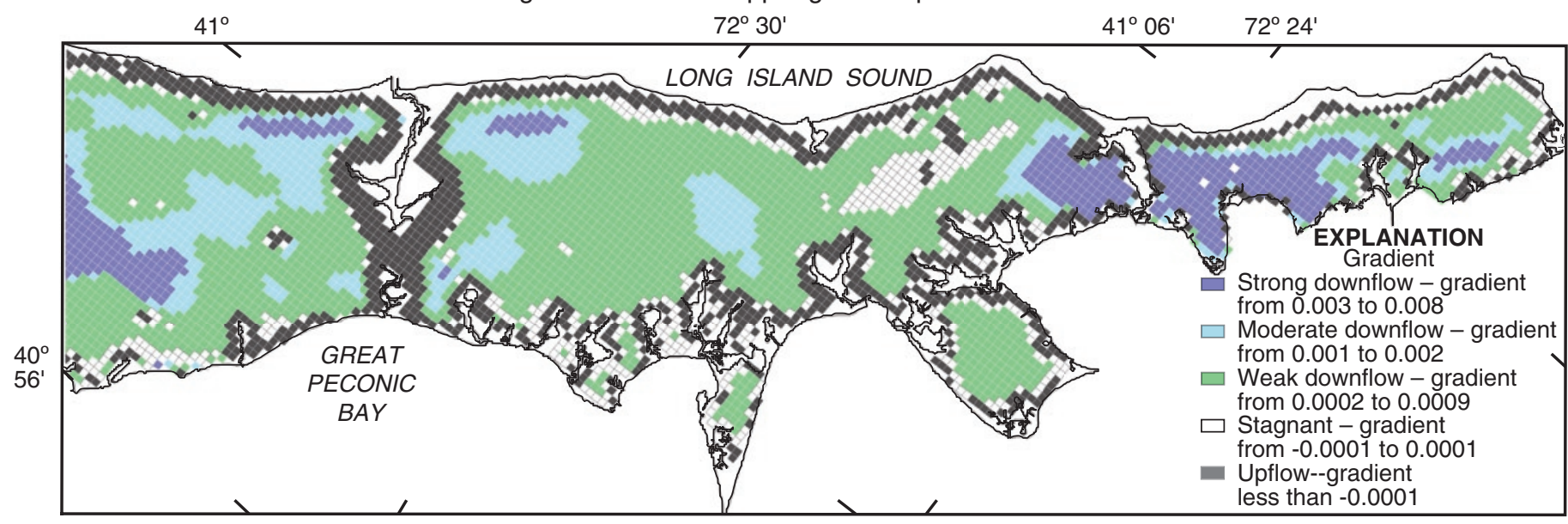

Base from U.S. Geological Survey digital data, 1:24,000,

Universal Transverse Mercator projection, NAD27, Zone 18

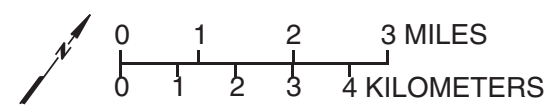

Figure 26. Simulated water-level and position of freshwater-saltwater interface position for the upper glacial aquifer zone B, 1994 average annual conditions on North Fork, Suffolk County, N.Y.: A. Simulated 1994 water levels in freshwater-flow system. B. Simulated 1994 freshwater-saltwater interface position. C. Simulated 1994 vertical gradient between upper glacial aquifer zones A and B. (Location is shown in fig. 1) 
A. Simulated 1994 water levels in freshwater-flow system in upper glacial aquifer zone C

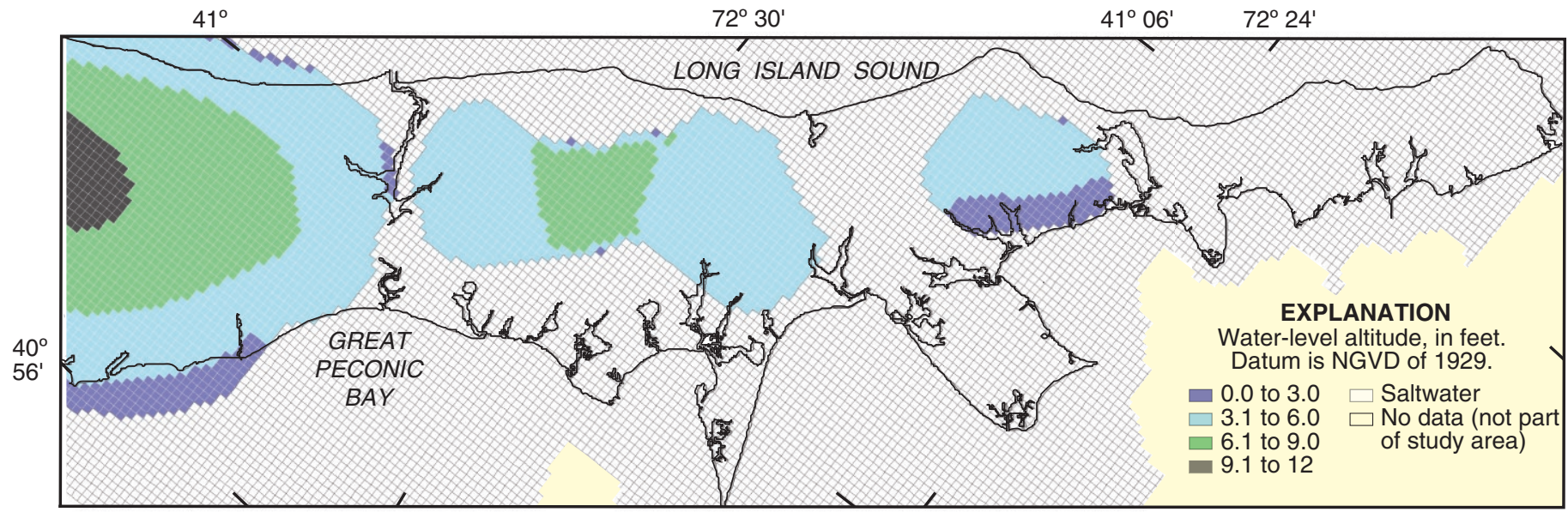

B. Simulated 1994 freshwater-saltwater interface position in upper glacial aquifer zone C

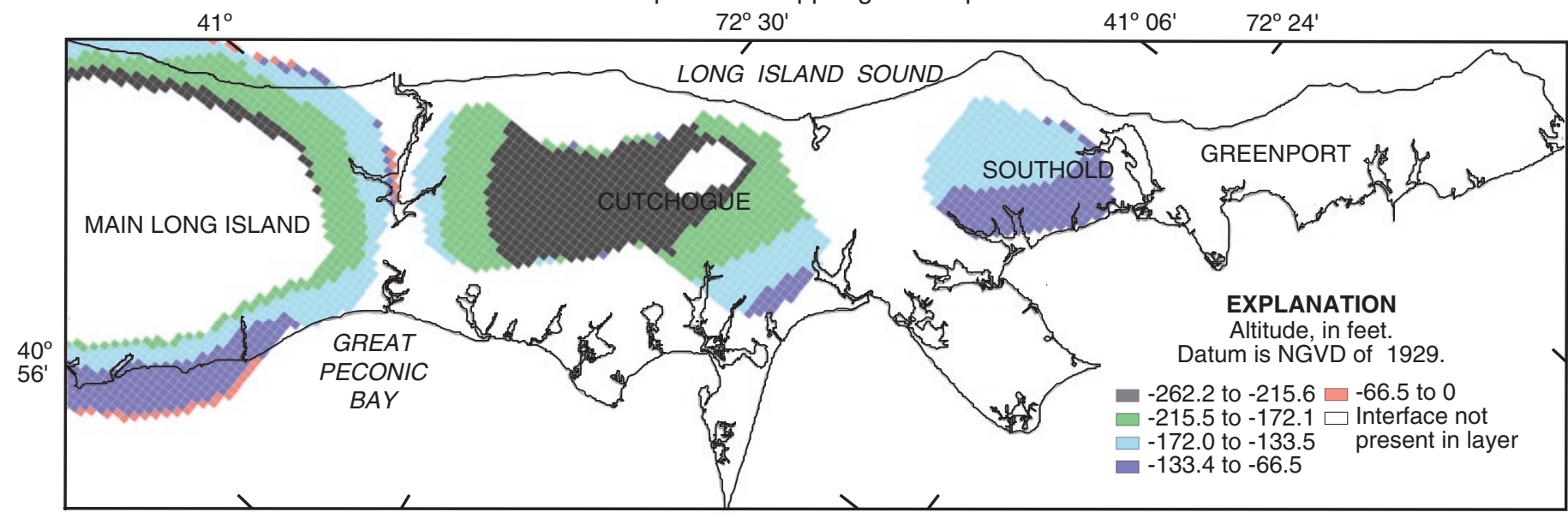

C. Simulated 1994 freshwater vertical gradient between upper glacial aquifer zones B and C

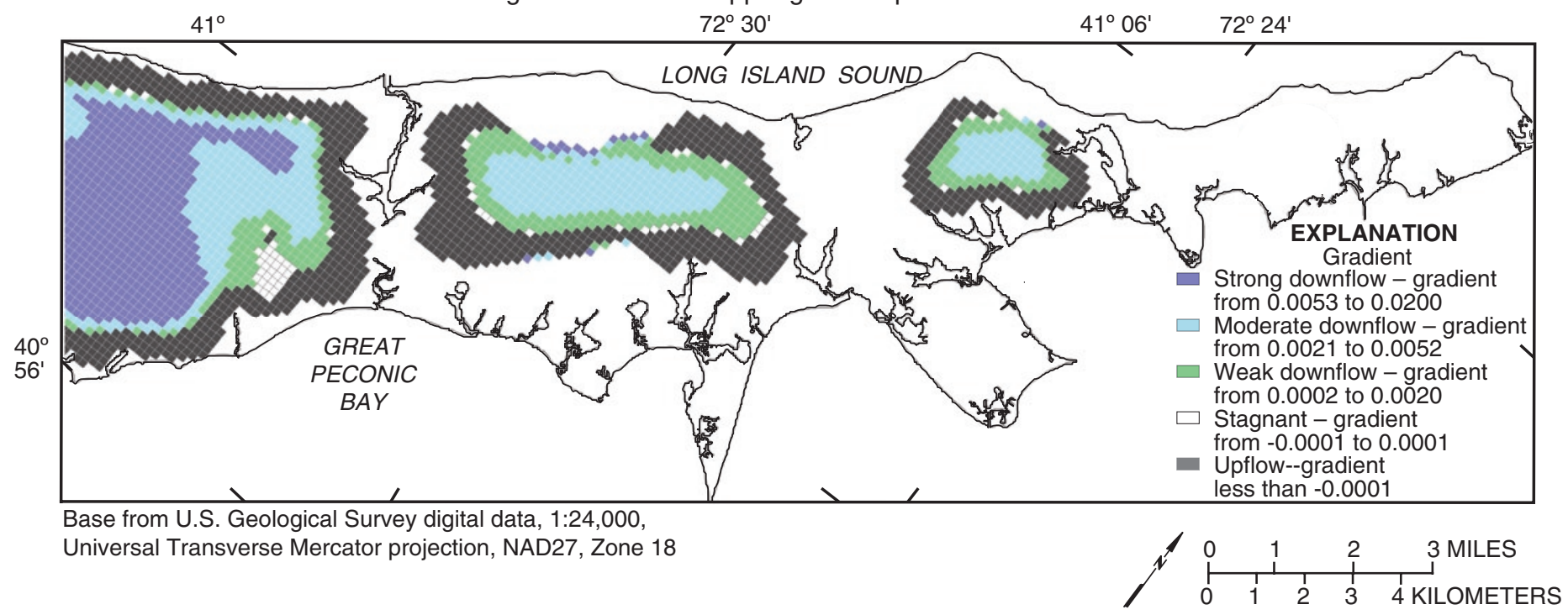

Figure 27. Simulated water level and freshwater-saltwater interface for the upper glacial aquifer zone C,1994 average annual conditions on North Fork, Suffolk County, N.Y.: A. Simulated 1994 water levels in freshwater-flow system. B. Simulated 1994 freshwater-saltwaterinterface position. C. Simulated 1994 vertical gradient between upper glacial aquifer zones B and C. (Location is shown in fig. 1) 


\section{Simulated Effects of Pumping and Drought on Ground-Water Levels and the Freshwater-Saltwater Interface on the North Fork of Long Island, New York}

The direction and magnitude of simulated vertical hydraulic gradients between upper glacial aquifer zone $\mathrm{A}$ and B (fig. 26C) indicate downflow below the recharge-mound peaks and upflow at the shore. The gradient is generally proportional to the vertical conductance of the upper confining unit (fig. 13A). Localized gradient reversals from downward to upward also are indicated at Laurel Lake (location is shown in fig. 20A) and at several wellfields.

The simulated head configuration and interface position in the upper glacial aquifer zone $\mathrm{C}$ (beneath the lower confining unit) are depicted in figures $27 \mathrm{~A}-\mathrm{B}$, respectively. Here the main Long Island sublens continues downward to the Magothy layer, and the Cutchogue sublens divides into Cutchogue and Southold sublenses, which are separated by saltwater underlying an embayment between Little Hog and Great Hog Necks. The Greenport and Southold sublenses terminate in zone $\mathrm{C}$. The western Cutchogue sublens continues downward into the Magothy layer.

The direction and magnitude of vertical hydraulic gradients between upper glacial aquifer zones B and C (fig. 27C) indicate regional downflow below the recharge mounds and upflow near freshwater-saltwater interfaces. A localized gradient reversal also is seen in an area of about 30 cells in the eastern part of the main Long Island sublens, where the lower confining unit is absent.

The simulated-head configuration and the position of the freshwater-saltwater interface in the Magothy aquifer are depicted in figures 28A-B. The main Long Island and Cutchogue sublenses terminate in mixed-water cells of the Magothy layer. Freshwater does not extend to the bottom of the layer.

The direction and magnitude of vertical hydraulic gradients (fig. 28C) show a characteristic downward component below recharge mounds and an upward component at interfaces; however, the Cutchogue sublens is not completely surrounded by upward flow; the configuration of layer structure allows downflow at the western side of the Cutchogue sublens.

The simulated vertical section A-A' (fig. 29) depicts the interface elevation in relation to hydrogeologic-unit and model-layer geometry. The deepest interface elevation is near the western edge of the section and extends through about 10 percent of the Magothy layer thickness. The shallowest interface elevation is at the eastern edge of the section and extends to the floor of Long Island Sound. Two distinct interface mounds occur beneath the Mattituck Inlet and Hashomomuck Pond embayments. Local interface depressions occur where confining units are thin and recharge mounds are nearby; however, the presence of significant flow vectors orthogonal to this section makes this correlation more difficult to visualize in vertical section than plan view (figs. 25-28).

\section{Simulation of Historical Record}

Ground-water flow and locations of freshwater-saltwater interfaces were simulated in an initial predevelopment phase under nonpumping conditions to provide the starting point for simulation of the historical record. The predevelopment simulation used the long-term (1959-99) mean rate of recharge from precipitation and the long-term average stream discharges. After simulation of 250 years, when a steady state was approached, the run was halted, and its results were used as the starting point for simulation of a 65 -year phase representing 1941 to 2005 . The pumping rates used for the simulated 65-year phase were seasonal and were apportioned among five periods, as listed in table 9; table 5 also provides (1) the simulated peak and off-peak rates of recharge from precipitation and public-supply return, and (2) the discharges from base flow, irrigation pumpage, and public-supply pumpage, for each of the five seasonal periods.

The sources of recharge and discharge data for each of five stress periods of the 65-year simulation are summarized in table 10. Seasonal public-supply pumpage and return flow rates for 1957, 1994, and 1998 are tabulated by water-supply district in appendix 6.

Simulated heads and interface positions obtained at the end of the 65-year historical simulation were then used as initial conditions for the two sets of four scenarios: one representing years 2006-20 under average-recharge conditions for the entire 15-year period, and the other representing average conditions except for a 5-year (2011-15) drought. All scenarios used the projected water-use values, as follows:

Scenario 1 simulated long-term rates of recharge from precipitation and water usage that was essentially a continuation of that used during the fifth (1996-2005) stress period (table 6 and appendix 6).

Scenarios 2 and 3 simulated most conditions used in scenario 1 except for increased rates of public-supply pumpage and return flow, summarized in table 6 and appendixes 7 and 8 . Return flow of public-supply pumpage was applied to areas shown in figure $2 \mathrm{E}$.

Scenario 4 simulated most conditions used in scenario 3 except for additional increases in public-supply pumpage and return flow (table 6 and appendix 9) and miscellaneous pumpage (appendix 10). Return flow of public-supply pumpage was applied to areas shown in figure $2 \mathrm{E}$.

The four drought scenarios used the same conditions as outlined above, except for a 20-percent reduction in recharge from precipitation and an offsetting increase in the agricultural irrigation requirement during the 5-year (2011-15) drought.

\section{Analysis of Projected Future Conditions}

The effects of pumping and recharge on ground-water flow and the freshwater-saltwater interface position in the eight 15-year (2006-20) water-supply scenarios under averagerecharge conditions with and without a 5-year (2011-15) drought are summarized below. The percent increases in pumpage and return flow rates used in each simulation are summarized in table 11. 
A. Simulated 1994 water levels in freshwater-flow system in Magothy model layer

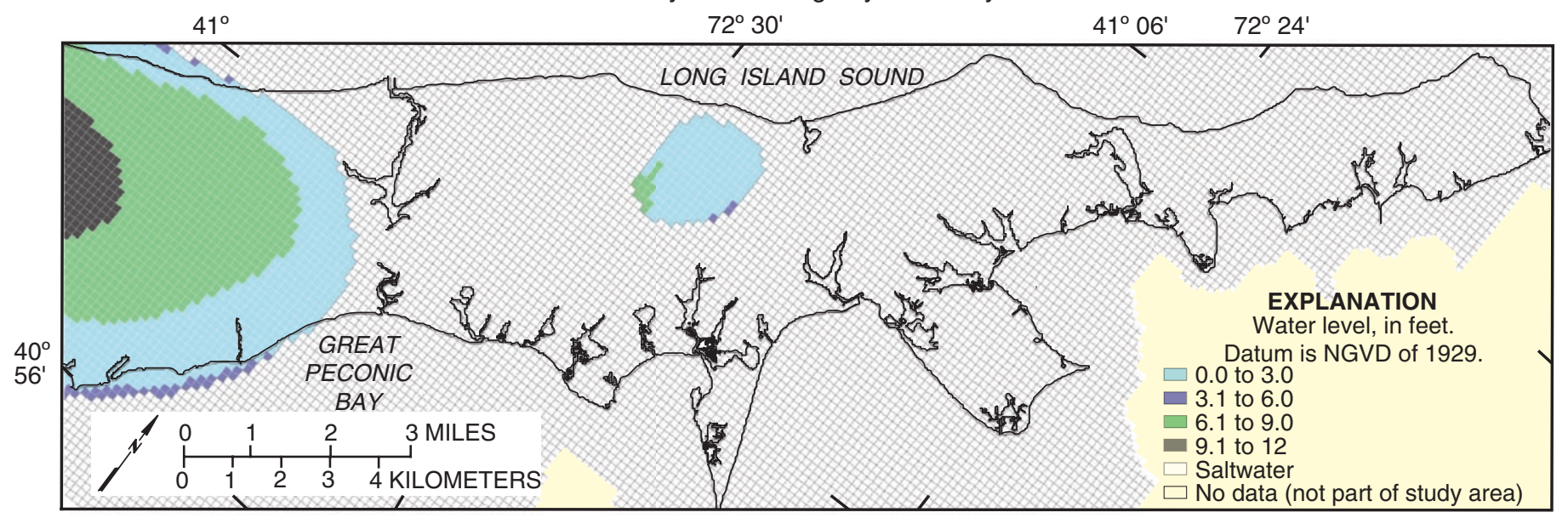

B. Simulated 1994 freshwater-saltwater interface position in Magothy model layer

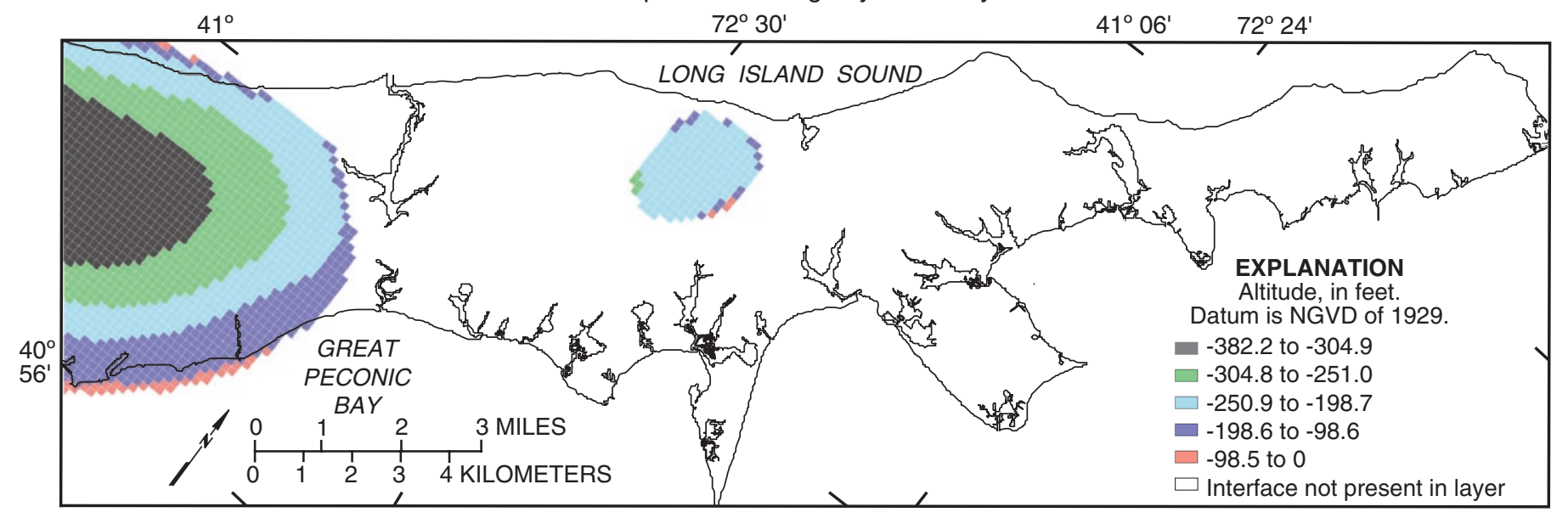

C. Simulated 1994 freshwater vertical gradient between the upper glacial aquifer zone $\mathrm{C}$ and the Magothy model layer

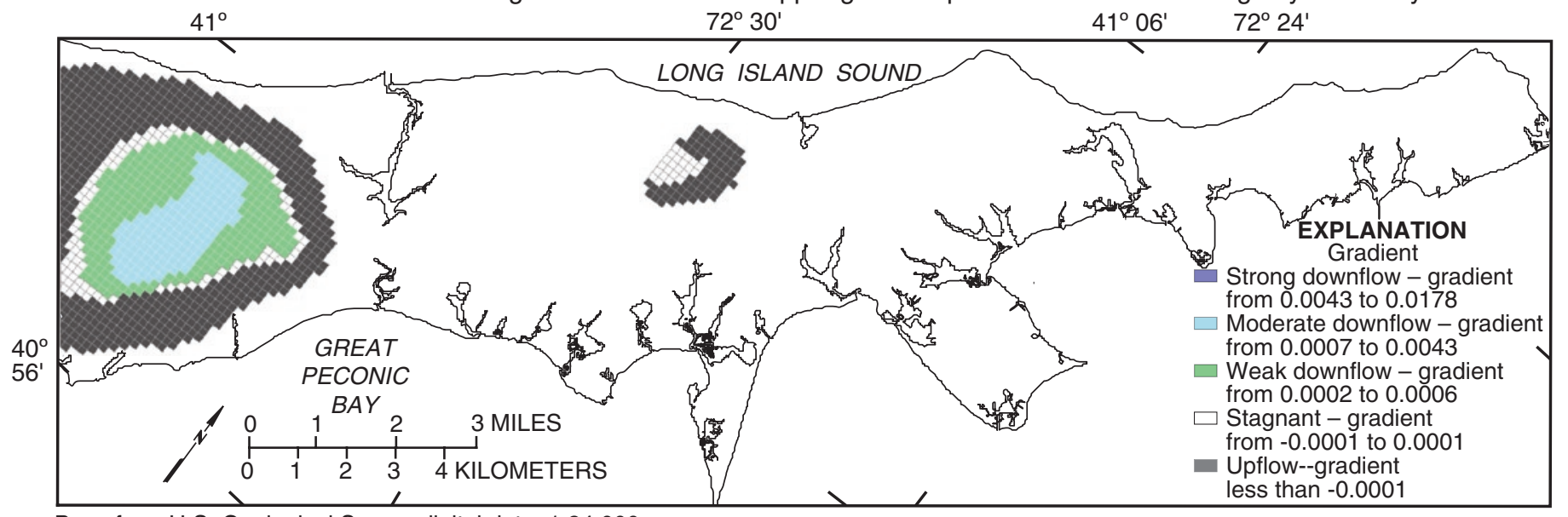

Base from U.S. Geological Survey digital data, 1:24,000,

Universal Transverse Mercator projection, NAD27, Zone 18

Figure 28. Simulated water level and position of freshwater-saltwater interface for the Magothy aquifer, 1994 average annual conditions on North Fork, Suffolk County, N.Y.: A. Simulated 1994 water levels in freshwater-flow system. B. Simulated 1994 freshwater-saltwater-interface position. C. Simulated 1994 vertical gradient between upper glacial aquifer zone $\mathrm{C}$ and Magothy layer. (Location is shown in fig. 1) 

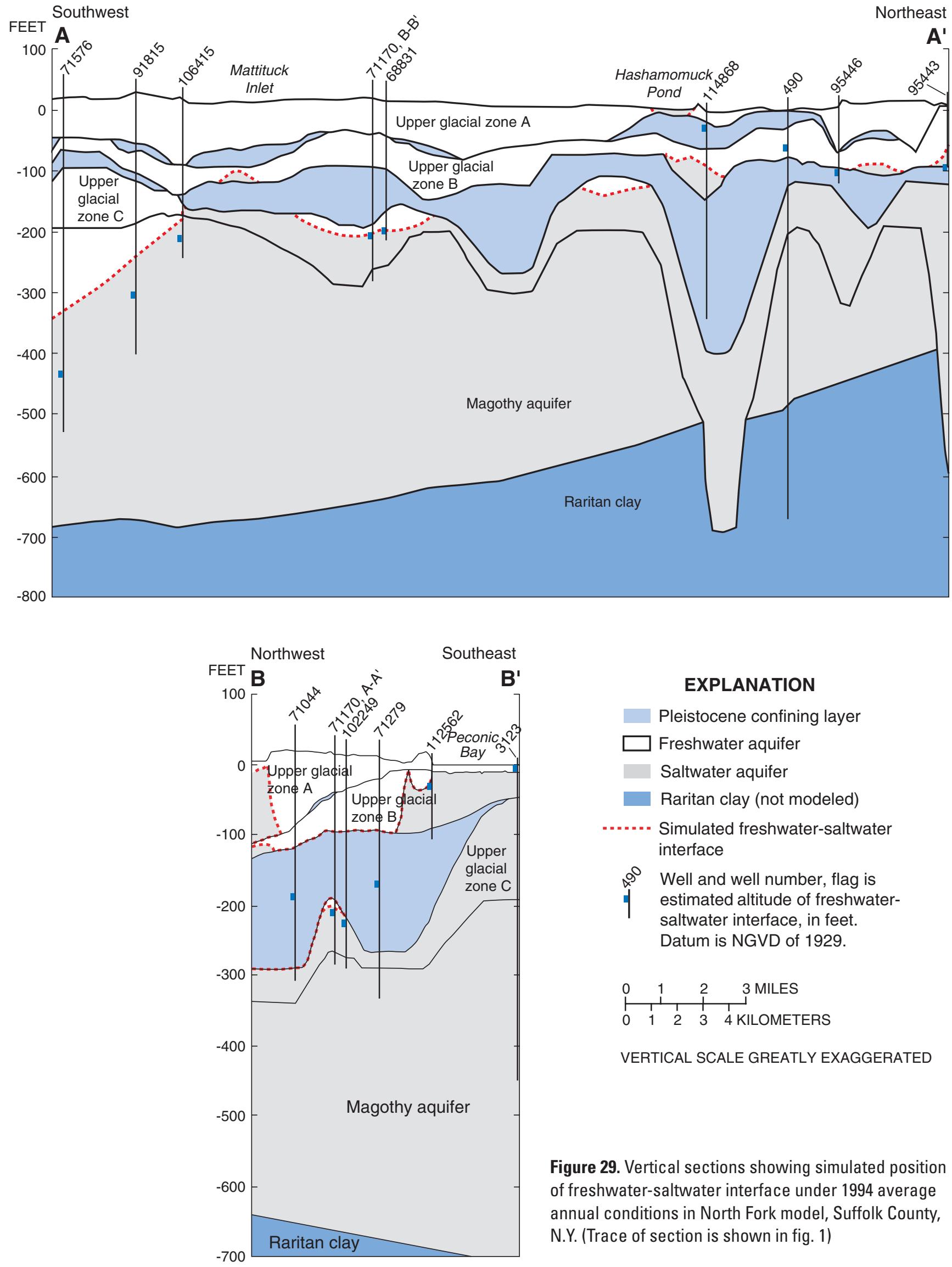

\section{EXPLANATION}

Pleistocene confining layer

Freshwater aquifer

Saltwater aquifer

Raritan clay (not modeled)

Simulated freshwater-saltwater interface

$\infty^{9} \quad$ Well and well number, flag is

estimated altitude of freshwatersaltwater interface, in feet. Datum is NGVD of 1929.

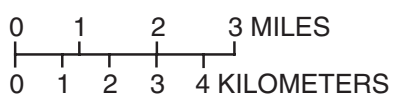

VERTICAL SCALE GREATLY EXAGGERATED

Figure 29. Vertical sections showing simulated position of freshwater-saltwater interface under 1994 average annual conditions in North Fork model, Suffolk County, N.Y. (Trace of section is shown in fig. 1) 
Table 9. Monthly distribution of recharge and discharge in North Fork model

\begin{tabular}{|c|c|c|c|c|c|c|}
\hline \multirow[b]{2}{*}{$\begin{array}{l}\text { Pumping } \\
\text { period }\end{array}$} & \multirow[b]{2}{*}{ Month } & \multicolumn{2}{|c|}{ Recharge } & \multicolumn{3}{|c|}{ Discharge } \\
\hline & & Precipitation & $\begin{array}{l}\text { Public-supply } \\
\text { return }\end{array}$ & Base flow & $\begin{array}{l}\text { Agricultural } \\
\text { pumpage }\end{array}$ & Public supply \\
\hline \multirow[t]{4}{*}{1} & January & Peak & Offpeak & Annual & None & Offpeak \\
\hline & February & Peak & Offpeak & Annual & None & Offpeak \\
\hline & March & Peak & Offpeak & Annual & None & Offpeak \\
\hline & April & Peak & Offpeak & Annual & None & Offpeak \\
\hline 2 & May & Offpeak & Peak & Annual & None & Offpeak \\
\hline \multirow[t]{3}{*}{3} & June & Offpeak & Peak & Annual & Total & Peak \\
\hline & July & Offpeak & Peak & Annual & Total & Peak \\
\hline & August & Offpeak & Peak & Annual & Total & Peak \\
\hline \multirow[t]{2}{*}{4} & September & Offpeak & Peak & Annual & None & Offpeak \\
\hline & October & Offpeak & Peak & Annual & None & Offpeak \\
\hline \multirow[t]{2}{*}{5} & November & Peak & Offpeak & Annual & None & Offpeak \\
\hline & December & Peak & Offpeak & Annual & None & Offpeak \\
\hline
\end{tabular}

Table 10. Data used for the five stress periods of the 65-year (1941-2005) simulation in North Fork model

\begin{tabular}{|c|c|c|c|c|c|c|}
\hline \multirow[b]{2}{*}{ Stress period } & \multicolumn{2}{|c|}{ Recharge } & \multicolumn{3}{|c|}{ Withdrawals } & \multirow[b]{2}{*}{ Mean base flows } \\
\hline & $\begin{array}{l}\text { Recharge from } \\
\text { precipitation }\end{array}$ & $\begin{array}{l}\text { Public-supply } \\
\text { return flow }\end{array}$ & $\begin{array}{l}\text { Agricultural } \\
\text { withdrawal }\end{array}$ & $\begin{array}{l}\text { Public-supply } \\
\text { pumpage }\end{array}$ & $\begin{array}{l}\text { Miscellaneous } \\
\text { pumpage }\end{array}$ & \\
\hline $1941-61$ & 1957 & 1957 & 1957 & 1957 & 1957 & 1959-99 \\
\hline 1962-66 (drought) & $1962-66$ & 1957 & $1962-66$ & 1957 & 1957 & 1959-99 \\
\hline $1967-70$ & 1957 & 1957 & 1957 & 1957 & 1957 & 1959-99 \\
\hline 1971-95 & 1992-94 & 1994 & 1994 & 1994 & 1994 & 1959-99 \\
\hline 1996-2005 & $1996-98$ & 1998 & 1999 & 1998 & 1994 & $1959-99$ \\
\hline
\end{tabular}

Table 11. Summary of water-supply scenarios for years 2006-20 in North Fork model

[Percent increases are in relation to scenario 1 rates.]

\begin{tabular}{cclll}
\hline Scenario & Public-supply pumpage & \multicolumn{1}{l}{ Public-supply return flow } & Miscellaneous pumpage & Agricultural pumpage \\
\hline \multicolumn{2}{l}{ Scenarios based on average-recharge conditions } & & \\
1 & 1998 rates & 1998 rates & 1994 rates & 1999 rates \\
2 & 186-percent increase & 121-percent increase & no increase & no increase \\
3 & 268-percent increase & 141-percent increase & no increase & no increase \\
4 & 365-percent increase & 165-percent increase & 157-percent increase & no increase \\
\hline
\end{tabular}

Scenarios based on drought conditions

Drought was applied to each of the above scenarios as a 20-percent decrease in long-term rate of recharge and a 20- percent increase in 1999 agricultural pumpage during years 2011-15. 


\section{Simulated Effects of Pumping and Drought on Ground-Water Levels and the Freshwater-Saltwater Interface on the North Fork of Long Island, New York}

Scenario 1 represents no change in the rates of water use from either the 1998 public-supply pumpage and return flow, the 1993-95 miscellaneous pumpage, or the 1999 rate of agricultural withdrawal. These years and rates were chosen because they provide the most reliable estimates of conditions during the projected period.

Scenario 2 incorporated two planned wells at Alvah's Lane and five proposed public-supply wellfields, and applied public-supply pumpage and return flow at 186 percent of the 1998 rates (table 11). Return flow of public-supply pumpage was applied to areas shown in figure $2 \mathrm{E}$. The rates of miscellaneous pumpage and agricultural withdrawal were not changed.

Scenario 3 incorporated two planned wells at Alvah's Lane and five proposed public-supply wellfields, and applied public-supply pumpage and return flow at 268 percent of the 1998 rates (table 11). Return flow of public-supply pumpage was applied to areas shown in figure $2 \mathrm{E}$. The rates of miscellaneous pumpage and agricultural withdrawal were not changed.

Scenario 4 incorporated two planned wells at Alvah's Lane and five proposed public-supply wellfields, and applied public-supply pumpage and return flow at 365 percent of the 1998 rates and miscellaneous pumpage at 157 percent of the 1993-95 rates (table 11). Return flow of public-supply pumpage was applied to areas shown in figure $2 \mathrm{E}$.

\section{Limitations of Analysis}

Several factors affect the reliability of conclusions drawn about the system and the certainty of predictions. Coarse model discretization entails averaging over large areas, depth intervals, and time intervals and therefore limits the precision of the simulated interface position and results in underestimation of its movement in response to localized stresses. The SHARP method inherently underestimates the movement of the potability interface through its method of representing freshwater and saltwater mixing, especially in the vicinity of pumped wells. As a result, a relatively small interface movement to within $50 \mathrm{ft}$ of a well screen is a cause for concern, as is a large percent change in the distance between the interface and the well screen, or upward movement of an interface through a confining unit.

\section{Results of Average-Recharge Simulations}

The four water-supply scenarios that simulated averagerecharge conditions used the long-term (1959-99) rate of recharge from precipitation, which is slightly smaller than the 1996-98 rate used for the 10-year period corresponding to 1996-2005. As a result, the model-generated water levels decreased, and interface positions moved upward and landward, in all four average-recharge scenarios. These changes were greater in scenarios 2,3 , and 4 than in scenario
1 as a result of the applied increases in pumpage (table 11). Results of simulation of the four scenarios under averagerecharge conditions are summarized below, and results for the first three scenarios are depicted in figures 30A-C; the results of simulation of the drought scenarios are discussed in the next section and depicted in figures 30D, E.

\section{Average-Recharge Scenario 1}

Wellfields at Brecknock Hall and Inlet Drive (locations shown in fig. 3C) were the most susceptible to saltwater intrusion in this scenario. Saltwater intrusion at well 1A (appendix 7) of Inlet Drive (S-105669, redeveloped as S108347) is indicated to begin around 1998 (fig. 30A); here the saltwater interface moves through the upper confining unit and enters the unconfined aquifer in which the well is screened. The confined aquifer is shown to contain freshwater and saltwater until the crossover (1996), after which it is fully salty. The interface position thereafter is indicated to be above the bottom of the upper aquifer.

\section{Average-Recharge Scenario 2}

Wellfields shown to be susceptible to saltwater intrusion in scenario 2 were those at Inlet Drive, Brecknock Hall, Main Bayview Road, and Islands End (locations shown in fig. 3C). The response of the Islands End wellfield at Well 8 (S15795) is depicted in figure 30B. Interface movement reverses from downward to upward in 2006. The interface travels only about $15 \mathrm{ft}$, but interface movement throughout this area is expected to cause additional localized upconing.

\section{Average-Recharge Scenario 3}

Upward movement of the saltwater interface at well S105669 during scenario 3 (fig. 30C) is more pronounced than in scenario 1. Capture of saltwater becomes evident at about year 2011, although chloride concentrations probably would begin to increase several years earlier because widespread interface movement generally causes additional localized upconing.

\section{Average-Recharge Scenario 4}

Simulation of scenario 4 indicated that wellfields at North Road and Alvah's Lane, in addition to those indicated during scenarios 1, 2, and 3, show some upward interface movement toward the well screen. Wellfields that were not susceptible to saltwater intrusion during scenario 4 were those at Ackerly Pond, Kenney's Road, Middle Road, North Road (Peconic), Rocky Point Road, and the hypothetical wellfield parcels shown in figure $3 \mathrm{E}$.

\section{Results of Drought Simulations}

Simulation of drought conditions entailed application of a 20-percent decrease in the long-term rate of recharge 
A. Scenario 1: Well S-105669 (redeveloped as S-108347)
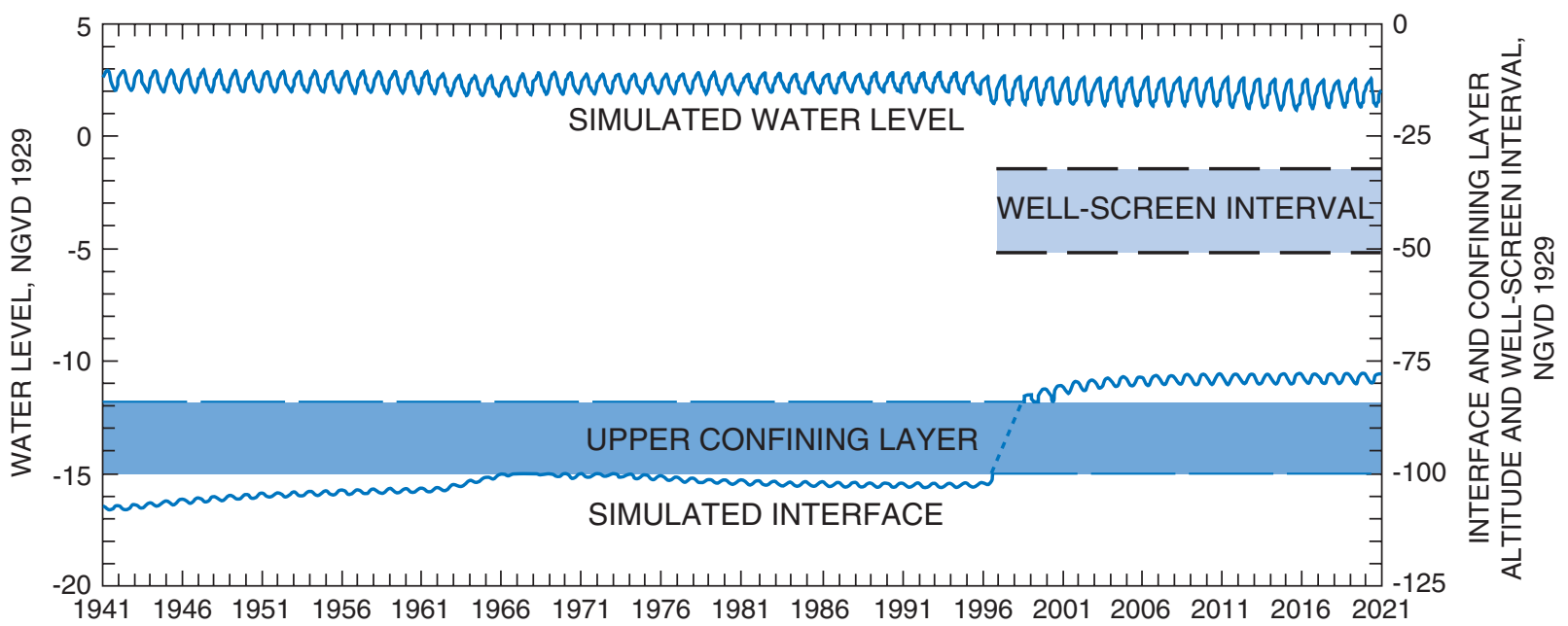

B. Scenario 2: Well S-15795

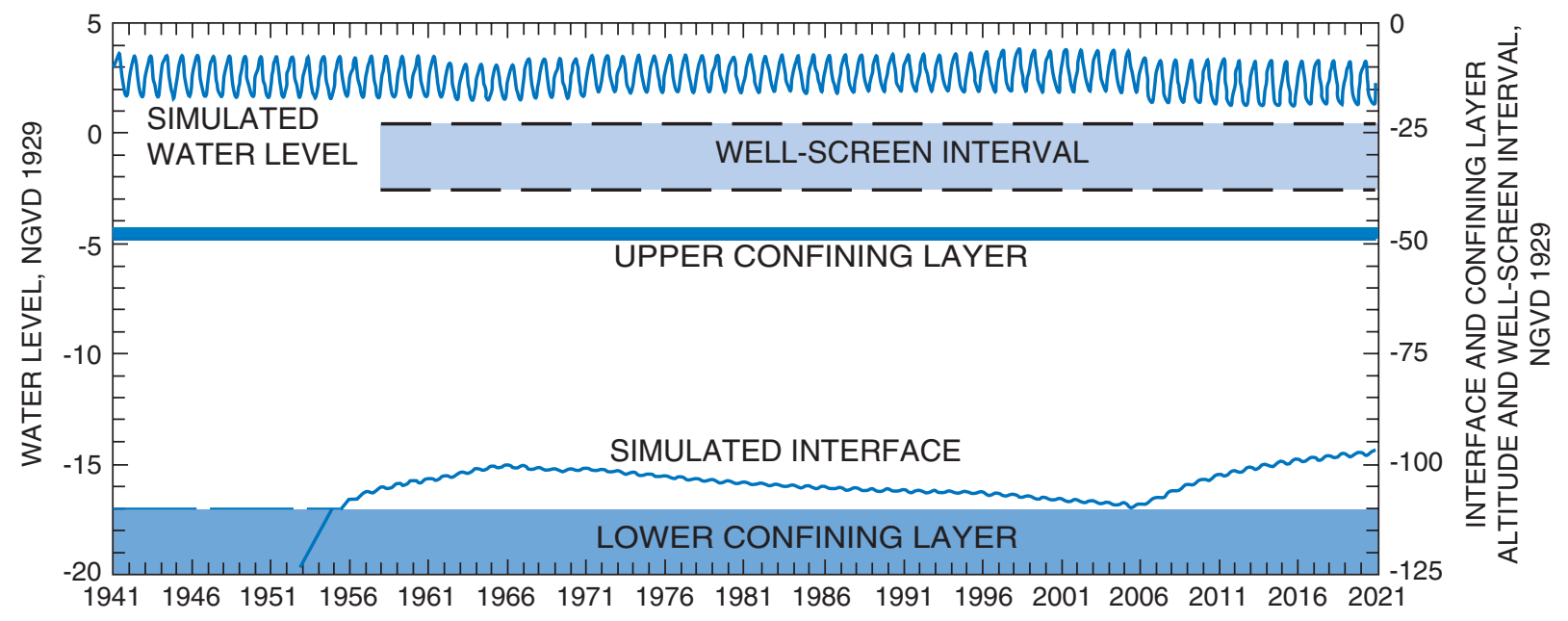

Figure 30. Vertical sections showing model-generated heads and freshwater-saltwater-interface positions at selected wells in scenarios 1 through 4 under simulated average-recharge conditions in North Fork model, Suffolk County, N.Y.: A. Scenario 1: Well S105669 (redeveloped as S108347). B. Scenario 2: Well S15795. (Well locations are shown in figs. 3C-E; pumpage values for each scenario are given in table 11.) (Location is shown in fig. 1)

from precipitation and an offsetting equivalent increase in the rate of agricultural withdrawal during the 5-year period corresponding to 2011-15. This period was chosen because it is the midpoint of the hypothetical period (2006-2020), and allows 5 years of recovery after the drought. The decreased rate of recharge during the hypothetical drought is essentially the same as that calculated for the study area during the drought of 1962-66, which affected most of the Northeast. The clearest indications of saltwater intrusion (scenarios 3 and 4), depicted in figures 30D and E, respectively, appear after the drought is over and normal recharge has resumed. This result indicates that these pumping rates may not be sustainable for the long term.

\section{Drought Scenario 1}

Upward movement of the saltwater interface in response to the addition of drought conditions to scenario 1 was greatest at well S-105669 at the Inlet Drive wellfield (fig. 3C), where the interface moved up $2 \mathrm{ft}$ during the drought (not illustrated).

\section{Drought Scenario 2}

Upward movement of the saltwater interface in response to the drought condition in scenario 2 was greatest at well S-15795 (Islands End, location shown in fig. 3C), where the interface moved up $2 \mathrm{ft}$ during the drought (not illustrated). 
C. Scenario 3: Well S-105669 (redeveloped as S-108347)
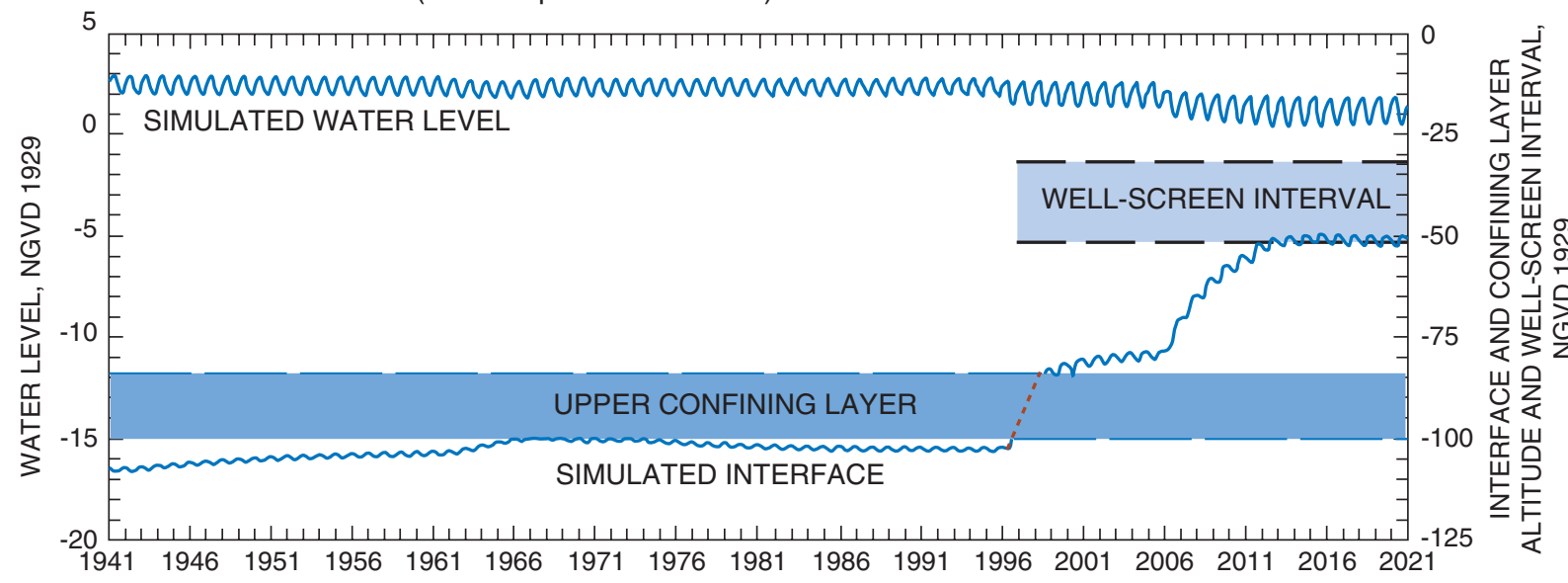

D. Drought scenario 3: Well H-190001

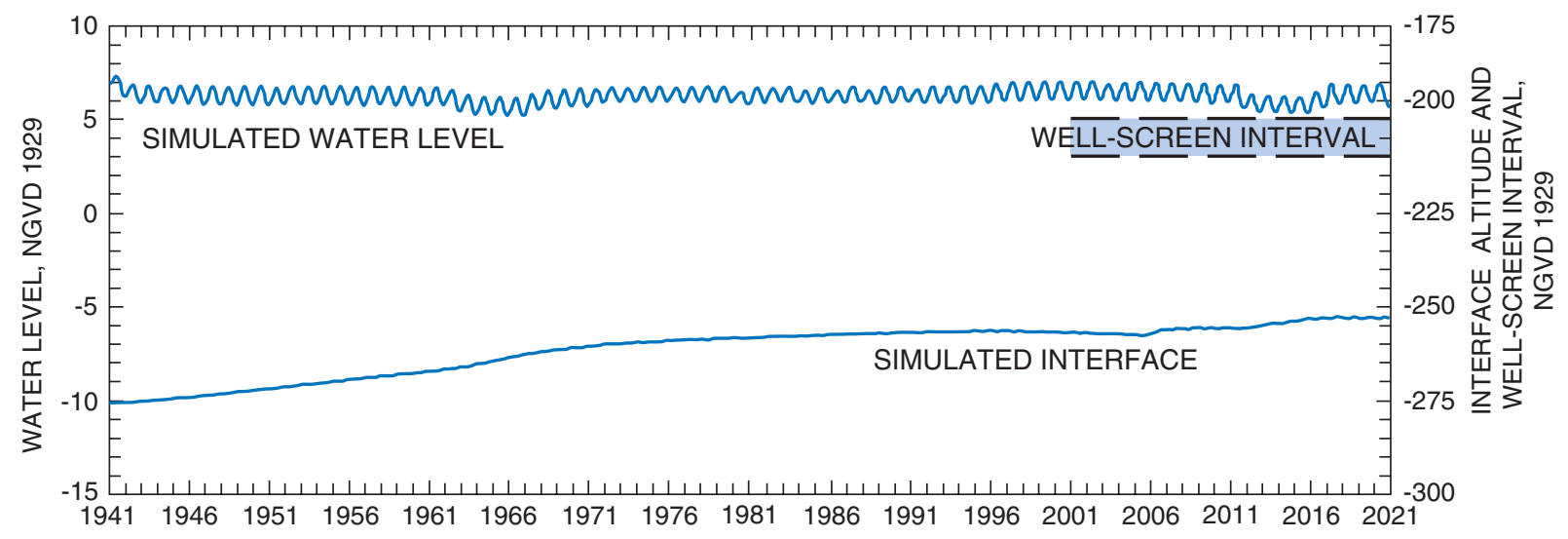

E. Drought scenario 4: Well S-24851

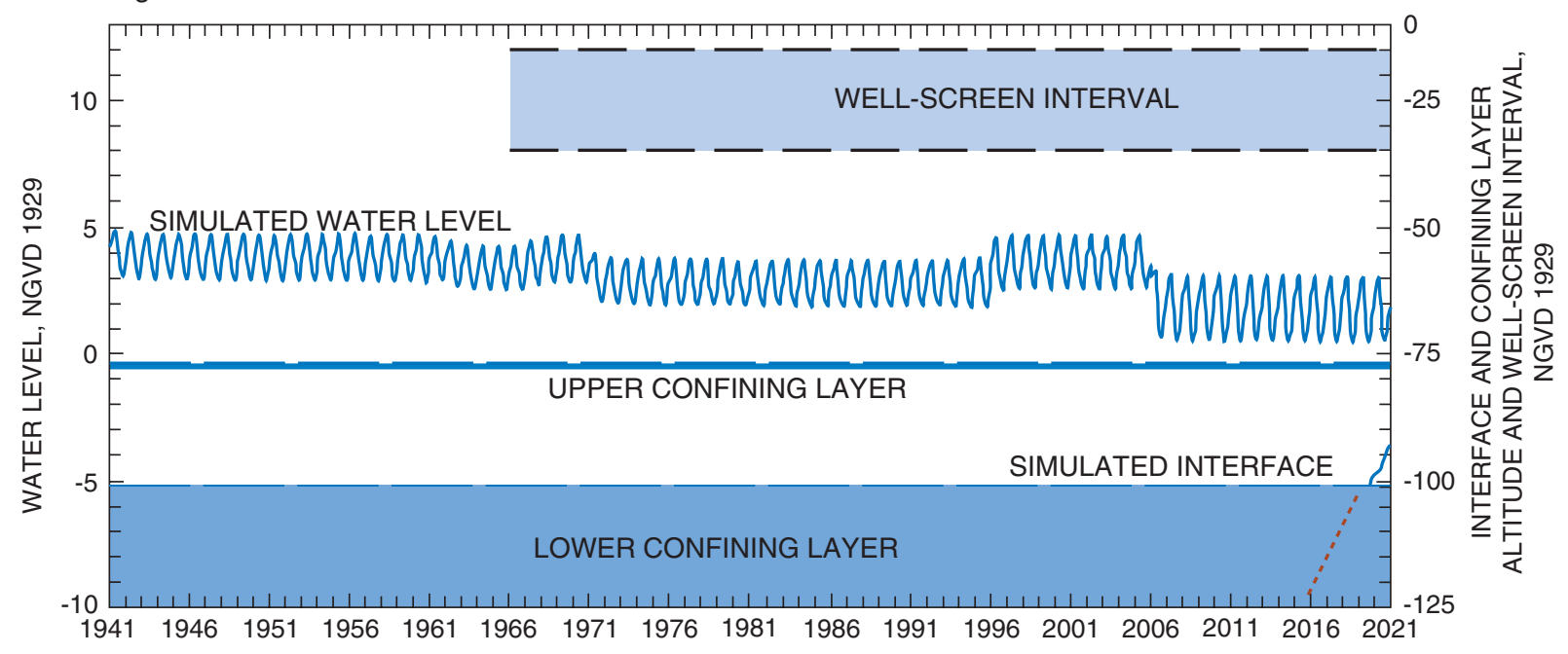

Figure 30. (continued) Vertical sections showing model-generated heads and freshwater-saltwater-interface positions at selected wells in scenarios 1 through 4 under simulated average-recharge conditions in North Fork model, Suffolk County, N.Y.: C. Scenario 3: Well S105669(redeveloped as S108347). D. Drought scenario 3: Well H19001. E. Drought scenario 4: Well S24851. (Well locations are shown in figs. 3C-E; pumpage values for each scenario are given in table 11.) (Location is shown in fig. 1) 


\section{Drought Scenario 3}

Upward movement of the saltwater interface in response to the drought condition in scenario 3 was greatest at well S-190001 at the Alvah's Lane wellfield (fig. 30D), where the interface moved up $3 \mathrm{ft}$ during the drought.

\section{Drought Scenario 4}

A breakthrough of the saltwater interface through the lower confining unit (fig. 30E) occurs in 2018 at well S24851 at the North Road wellfield (fig. 3D). The upper confining unit is not present at this location; thus, the main impediment to movement of the interface to the well screen has been crossed.

\section{Summary and Conclusions}

Ground water, the sole source of drinking water on the North Fork of eastern Long Island, occurs only in a series of hydraulically isolated freshwater lenses of varying thickness. Future increases in the demand for drinking water and irrigation water could, in a prolonged drought, cause drawdowns that induce saltwater intrusion and upconing at public-supply wells. As the demand for the limited supply of freshwater increases, information on the effects of current and future pumping and drought on ground-water levels within the freshwater systems, and especially on the position of the freshwater-saltwater interface, will be needed by watersupply managers. This need for information on the ability of the freshwater systems to meet future increased demands prompted a study by the USGS, in cooperation with SCWA, to develop a ground-water-flow model of the North Fork aquifer system and to analyze the effects of simulated pumping and recharge rates on water levels and the position of the freshwater-saltwater interface.

The modeled area encompasses all of the Town of Southold and the easternmost part of the Town of Riverhead. The hydrogeology of the North Fork was evaluated from published information and from exploratory drilling of five deep wells during this study. The hydraulic properties of hydrogeologic units were compiled from previous investigations of unconsolidated deposits on Long Island and those in similar settings on western Cape Cod, Massachusetts.

The code used for the model was SHARP, a quasithree dimensional, finite-difference method of simulating freshwater and saltwater flow simultaneously. The position of the freshwater-saltwater interface was simulated in four hydrogeologic units: (1) the unconfined part of the upper glacial aquifer, (2) the part of upper glacial aquifer that underlies an upper confining unit, (3) the part of the upper glacial aquifer that underlies a lower confining unit, and (4) the Magothy aquifer. The active model boundary extends vertically through all layers and coincides with natural hydrologic boundaries where possible, or is specified at locations at sufficient distance from points of stress so as not to affect simulation results.

The model was calibrated under a quasi-steady-state simulation of 1994 average annual conditions. Modelgenerated water levels were compared statistically with water levels measured in March-April 1994, and the modelgenerated freshwater-saltwater interface position was compared with long-term estimated equilibrium positions. Model-generated water levels based on the transient-state simulation of 1941-2005 seasonal conditions were plotted as time series along with historical hydrographs.

Ground-water levels and the freshwater-saltwater interface were simulated initially for a long-term (250-year) period under average annual pumping and recharge conditions that generally corresponded to those of 1994 . When the simulated heads and interface positions reached a quasi-steady state deemed representative of 1994 conditions, a long-term (250-year) simulation under average annual predevelopment (nonpumping) conditions was run. Simulated predevelopment heads and interface positions were then used as initial conditions for a simulated 65-year period (1941-2005) at seasonal pumping and recharge rates. The simulated heads and interface positions obtained at the end of this period were then used as initial conditions for a simulated 15-year period under seasonal conditions corresponding to years 2006-20. Two sets of four water-supply scenarios - one set with average-recharge conditions, the other with the same conditions except for a 5-year simulated drought (2011-15) — were run in which future water-use projections were applied. The simulated drought conditions were represented as a 20-percent decrease in the long-term rate of recharge from precipitation and a 20-percent increase in the 1999 agricultural pumpage during the 5-year drought.

Upward movement of the freshwater-saltwater interface during the hypothetical scenarios should be considered a cause for concern if there is a potential for saltwater intrusion; namely, if the interface reaches a position within $50 \mathrm{ft}$ of a well screen, if a large percent change occurs in the distance between the interface and the well screen, or if the interface moves through a confining unit. Simulations predict there is a potential for saltwater intrusion at the wellfields of Inlet Drive, Brecknock Hall, Main Bayview Road, Islands End, North Road and Alvah's Lane. Wellfields that did not show a potential for saltwater intrusion were those at Ackerly Pond, Kenney's Road, Middle Road, Rocky Point Road, and the hypothetical-wellfield parcels. 


\section{References Cited}

Baier, J.H., and Moran, Dennis, 1981, Status report on aldicarb contamination of groundwater as of September 1981: Hauppauge, N.Y., Suffolk County Department of Health Services, $45 \mathrm{p}$.

Baier, J.H., and Robbins, S.F., 1982a, Report on the occurrence and movement of agricultural chemicals in groundwater-North Fork of Suffolk County: Hauppauge, N.Y., Suffolk County Department of Health Services, 71 p.

Baier, J.H., and Robbins, S.F., 1982b, Report on the occurrence and movement of agricultural chemicals in groundwater-South Fork of Suffolk County: Hauppauge, N.Y., Suffolk County Department of Health Services, 68 p.

Barlow, P.M., and Wild, E.C., 2002, Bibliography on the occurrence and intrusion of saltwater intrusion in aquifers along the Atlantic coast of the United States: U.S. Geological Survey Open-File Report 02-235, 30 p.

Bohn-Buxton, D.E., Buxton, H.T., and Eagen, V.K., 1996, Simulation of ground-water flow paths and traveltime in relation to tritium and aldicarb concentrations in the upper glacial aquifer on the North Fork, Long Island, New York: U.S. Geological Survey Open-File Report 95-761, 36 p.

Cohen, Philip, Franke, O.L., and Foxworthy, B.L., 1968, An atlas of Long Island's water resources: New York State Water Resources Commission Bulletin 62, 117 p.

Crandell, H.C., Jr., 1963, Geology and ground-water resources of the Town of Southold, Suffolk County, New York: U.S. Geological Survey Water-Supply Paper 1619-GG, $36 \mathrm{p}$.

Essaid, H.I., 1990, The computer model SHARP, a quasi-three-dimensional finite-difference model to simulate freshwater and saltwater flow in layered coastal aquifer systems: U.S. Geological Survey Water-Resources Investigations Report 90-4130, $181 \mathrm{p}$.

Franke, O.L., and McClymonds, N.E., 1972, Summary of the hydrologic situation on Long Island, New York as a guide to water-management alternatives: U.S. Geological Survey Professional Paper 627-F, 59 p.

Fuller, M.L., 1914, The geology of Long Island, New York: U.S. Geological Survey Professional Paper 82, 231 p.

Hoffman, J.F., 1961, Hydrology of the shallow groundwater reservoir of the Town of Southold, Suffolk County, Long Island, New York: New York State Water Resources Commission Bulletin GW-45, 49 p.

Kontis, A.L., 1999, Simulation of freshwater-saltwater interfaces in the Brooklyn-Queens aquifer system, Long Island, New York: U.S. Geological Survey Water-Resources Investigations Report 98-4067, 26 p.

Masterson, J.P., and Barlow, P.M., 1997, Effects of simulated ground-water pumping and recharge on groundwater flow in Cape Cod, Martha's Vineyard, and Nantucket Island basins, Massachusetts: U.S. Geological Survey WaterSupply Paper 2447, 79 p.
Misut, P.E., and McNew-Cartwright, E.R., 1996, Calibration of a ground-water-flow model by regression: U.S. Geological Survey Open-File Report 95-388, 11 p.

Nemickas, Bronius and Koszalka, E.J., 1982, Geohydrologic appraisal of water resources of the South Fork, Long Island, New York: U.S. Geological Survey WaterSupply Paper 2073, 55 p.

Nemickas, Bronius, Mallard, G.E., and Reilly, T.E., 1989, Availability and historical development of ground-water resources of Long Island, New York-an introduction: U.S. Geological Survey Water-Resources Investigations Report 88-4113, 43 p.

Peterson, D.S., 1987, Ground-water recharge rates in Nassau and Suffolk Counties, New York: U.S. Geological Survey Water-Resources Investigations Report 86-4181, 19 p.

Pope, D.A., and Gordon, A.D., 1999, Simulation of ground-water flow and movement of the freshwater-saltwater interface in the New Jersey Coastal Plain: U.S. Geological Survey Water-Resources Investigations Report 98-4216, $159 \mathrm{p}$.

Prince, K.R., 1986, Ground-water assessment of the Montauk area, Long Island, New York: U.S. Geological Survey Water-Resources Investigations Report 85-4013, $103 \mathrm{p}$.

Reilly, T.E., 1993, Analysis of ground-water systems in freshwater-saltwater environments, in Alley, W.M., ed., Regional ground-water quality: New York, Van Nostrand Reinhold, p. 443-469.

Richardson, D.L., 1993, Hydrogeology and analysis of the ground-water-flow system of the eastern shore, Virginia: U.S. Geological Survey Water-Supply Paper 2401, 108 p.

Roy F. Weston, Inc., 1992, Draft groundwater management study report: Carle Place, N.Y., 48 p.

Schubert, C.E., 1998, Areas contributing ground water to the Peconic Estuary, and ground-water budgets for the North and South Forks and Shelter Island, eastern Suffolk County, New York: U.S. Geological Survey Water-Resources Investigations Report 97-4136, 36 p., 1 pl.

Schubert, C.E., 1998, Ground-water flow paths and traveltime to three small embayments within the Peconic Estuary, eastern Suffolk County, New York: U.S. Geological Survey Water-Resources Investigations Report 98-4181, 41 p.

Schubert, C.E., Bova, R.G., and Misut, P.E., 2004, Hydrogeologic framework of the North Fork and surrounding areas, Long Island, New York: U.S. Geological Survey WaterResources Investigations Report 02-4284, 4 sheets.

Soren, Julian, and Stelz, W.G., 1984, Aldicarb-pesticide contamination of ground water in eastern Suffolk County, Long Island, New York: U.S. Geological Survey WaterResources Investigations Report 84-4251, 34 p.

Spitz, F.J., 1998, Analysis of ground-water flow and saltwater encroachment in the shallow aquifer system of Cape May County, New Jersey: U.S. Geological Survey WaterSupply Paper 2490, 51 p. 
Steenhius, T.S., Jackson, C.D., Kung, S.K.J., and Brutsaert, W., 1985, Measurement of groundwater recharge on eastern Long Island, New York, USA: Journal of Hydrology, v. 79, p. 145-169.

Suffolk County Department of Planning, 2001, Saturation population analysis--Eastern Suffolk County: Hauppauge, N.Y., 20 p.
Suter, Russell, de Laguna, Wallace, and Perlmutter, N.M., 1949, Mapping of geologic formations and aquifers of Long Island, New York: New York State Water Power and Control Commission Bulletin GW-18, 212 p.

Veatch, A.C., Slichter, C.S., Bowman, Isaiah, Crosby, W.O., and Horton, R.E., 1906, Underground water resources of Long Island, New York: U.S. Geological Survey Professional Paper 44, 394 p. 


\section{Appendix}

1. Estimated 1957 annual and seasonal pumpage on the North Fork, Suffolk County, N.Y., by water-supply district . ...... 45

2. Estimated 1994 public-supply pumpage on the North Fork, Suffolk County, N.Y., by water-supply district . ............ 46

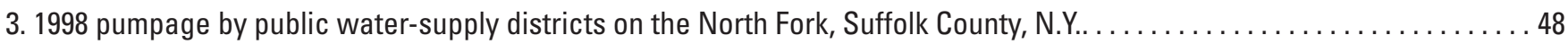

4. Reported and estimated annual 1993-95 pumpage by commercial-supply wells on the North Fork, Suffolk County, N.Y. . . . 50

5. Annual, seasonal, and long-term precipitation at Bridgehampton, Greenport, and Riverhead, Suffolk County, N.Y., and

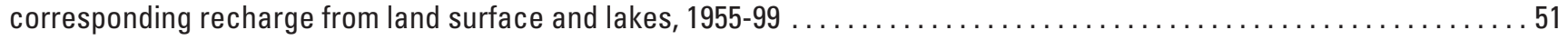

6. Modeled public water-supply pumpage and return-flow rates for 1957, 1994, 1998, and 2020 on the North Fork, Suffolk

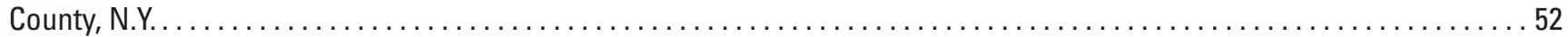

7. Pumpage at present, planned, and proposed public water-supply wellfields on the North Fork, Suffolk County, N.Y,

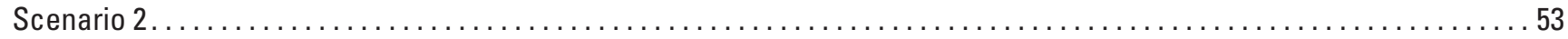

8. Pumpage at present, planned, and proposed public water-supply wellfields on the North Fork, Suffolk County, N.Y.,

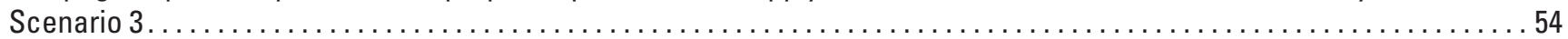

9. Pumpage at present, planned, and proposed public water-supply wellfields on the North Fork, Suffolk County, N.Y.,

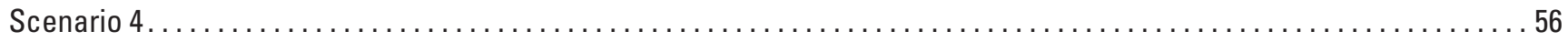

10. Pumpage at present, planned, and proposed commercial-supply wells on the North Fork, Suffolk County, N.Y., Scenario 4 . 
Appendix 1. Estimated 1957 annual and seasonal pumpage on the North Fork, Suffolk County, N.Y., by water-supply district

[Well locations are shown in fig. 21. gal/min, gallons per minute. $\mathrm{ft}^{3} / \mathrm{s}$, cubic feet per second. Dash (--) indicates no data available.]

\begin{tabular}{|c|c|c|c|c|c|c|c|c|c|c|c|c|c|}
\hline \multirow{4}{*}{$\begin{array}{c}\text { Wellfield } \\
\text { name }\end{array}$} & \multirow{4}{*}{$\begin{array}{c}\text { Well } \\
\text { no. }\end{array}$} & \multirow{4}{*}{$\begin{array}{c}\text { Well } \\
\text { identi- } \\
\text { fier }\end{array}$} & \multirow{4}{*}{$\begin{array}{c}\text { Well } \\
\text { capacity } \\
\text { (gal/min) }\end{array}$} & \multirow{4}{*}{$\begin{array}{c}\text { Estimated } \\
\text { annual } \\
\text { pumpage } \\
\text { (gal x 103) }\end{array}$} & \multirow{2}{*}{\multicolumn{3}{|c|}{$\begin{array}{c}\text { Average annual } \\
\text { pumpage }\end{array}$}} & \multicolumn{6}{|c|}{ Monthly pumping rate } \\
\hline & & & & & & & & \multicolumn{3}{|c|}{ June through August } & \multicolumn{3}{|c|}{ September through May } \\
\hline & & & & & \multicolumn{2}{|c|}{ Rate } & \multirow{2}{*}{$\begin{array}{l}\text { Percent of } \\
\text { capacity }\end{array}$} & \multicolumn{2}{|c|}{ Rate } & \multirow{2}{*}{$\begin{array}{c}\text { Percent of } \\
\text { capacity }\end{array}$} & \multicolumn{2}{|c|}{ Rate } & \multirow{2}{*}{$\begin{array}{c}\text { Percent of } \\
\text { capacity }\end{array}$} \\
\hline & & & & & gal/min & $\mathrm{ft}^{3} / \mathrm{s}$ & & gal/min & $\mathbf{f t}^{3} / \mathbf{s}$ & & gal/min & $\mathrm{ft}^{3} / \mathrm{s}$ & \\
\hline \multicolumn{14}{|c|}{ FORMER VILLAGE OF GREENPORT WATER SUPPLY (wellfield names are those associated with former Greenport Water District) } \\
\hline Plant no. 1 & -- & S-1668 & ${ }^{\mathrm{a}} 150$ & 19,950 & 38.0 & 0.085 & 25.30 & 57.7 & 0.129 & 38.46 & 31.4 & 0.070 & 20.92 \\
\hline \multirow[t]{2}{*}{ Plant no. 3} & $\begin{array}{c}-- \\
1\end{array}$ & $\begin{array}{l}\text { S-1669 } \\
\text { S-1673 }\end{array}$ & $\begin{array}{r}\text { a } 150 \\
167\end{array}$ & $\begin{array}{l}19,950 \\
22,167\end{array}$ & $\begin{array}{l}38.0 \\
42.2\end{array}$ & $\begin{array}{l}0.085 \\
0.094\end{array}$ & $\begin{array}{l}25.30 \\
25.30\end{array}$ & $\begin{array}{l}57.7 \\
64.1\end{array}$ & $\begin{array}{l}0.129 \\
0.143\end{array}$ & $\begin{array}{l}38.46 \\
38.46\end{array}$ & $\begin{array}{l}31.4 \\
34.9\end{array}$ & $\begin{array}{l}0.070 \\
0.078\end{array}$ & $\begin{array}{l}20.92 \\
20.92\end{array}$ \\
\hline & 2 & S-1674 & 167 & 22,167 & 42.2 & 0.094 & 25.30 & 64.1 & 0.143 & 38.46 & 34.9 & 0.078 & 20.92 \\
\hline \multirow[t]{2}{*}{ Plant no. 4} & $\begin{array}{l}6 \\
6\end{array}$ & $\begin{array}{l}\text { S-1678 } \\
\text { S-3697 }\end{array}$ & $\begin{array}{l}167 \\
200\end{array}$ & $\begin{array}{l}22,167 \\
26,600\end{array}$ & $\begin{array}{l}42.2 \\
50.6\end{array}$ & $\begin{array}{l}0.094 \\
0.113\end{array}$ & $\begin{array}{l}25.30 \\
25.30\end{array}$ & $\begin{array}{l}64.1 \\
76.9\end{array}$ & $\begin{array}{l}0.143 \\
0.171\end{array}$ & $\begin{array}{l}38.46 \\
38.46\end{array}$ & $\begin{array}{l}34.9 \\
41.8\end{array}$ & $\begin{array}{l}0.078 \\
0.093\end{array}$ & $\begin{array}{l}20.92 \\
20.92\end{array}$ \\
\hline & 7 & S-3698 & 200 & 26,600 & 50.6 & 0.113 & 25.30 & 76.9 & 0.171 & 38.46 & 41.8 & 0.093 & 20.92 \\
\hline subtotal $^{\mathrm{b}}$ & & & 1,201 & 159,601 & 303.7 & 0.677 & & 461.6 & 1.028 & & 251.1 & 0.560 & \\
\hline \multicolumn{14}{|c|}{ FORMER NORTH FORK WATER COMPANY } \\
\hline \multirow[t]{4}{*}{ Plant no. 5} & 1 & S-169 & 250 & 6,250 & 11.9 & 0.026 & 4.76 & 18.1 & 0.040 & 7.23 & 9.8 & 0.022 & 3.93 \\
\hline & 2 & S-170 & a250 & 6,250 & 11.9 & 0.026 & 4.76 & 18.1 & 0.040 & 7.23 & 9.8 & 0.022 & 3.93 \\
\hline & 3 & S-3045 & 250 & 6,250 & 11.9 & 0.026 & 4.76 & 18.1 & 0.040 & 7.23 & 9.8 & 0.022 & 3.93 \\
\hline & 4 & S-4163 & 50 & 1,250 & 2.4 & 0.005 & 4.76 & 3.6 & 0.008 & 7.23 & 2.0 & 0.004 & 3.93 \\
\hline subtotal $^{\mathrm{b}}$ & & & 800 & 20,000 & 38.1 & 0.085 & & 57.89 & 0.129 & & 31.5 & 0.070 & \\
\hline TOTAL & & & 2,001 & 179,600 & 341.7 & 0.761 & & 519.4 & 1.157 & & 282.5 & 0.629 & \\
\hline
\end{tabular}

${ }^{a}$ Estimated well capacity.

${ }^{\mathrm{b}}$ Total may not equal the sum of values because of rounding to significant digits. 
Appendix 2.. Estimated 1994 public-supply pumpage on the North Fork, Suffolk County, N.Y., by water-supply district

Monthly pumpage (thousands of gallons)

\begin{tabular}{|c|c|c|c|c|c|c|c|c|c|c|c|c|c|c|c|c|}
\hline $\begin{array}{c}\text { Wellfield } \\
\text { name }\end{array}$ & $\begin{array}{c}\text { Well } \\
\text { no. }\end{array}$ & $\begin{array}{c}\text { Well } \\
\text { identifier }^{\mathrm{a}}\end{array}$ & $\begin{array}{l}\text { capacity. } \\
\text { (gal/min) }\end{array}$ & Jan & Feb & Mar & Apr & May & Jun & Jul & Aug & Sep & Oct & Nov & Dec & Total \\
\hline \multicolumn{17}{|c|}{ FORMER VILLAGE OF GREENPORT WATER SUPPLY (wellfield names are those associated with former Greenport Water District) } \\
\hline Plant no. 3 & 1 & 1673 & 167 & 30 & 0 & 33 & 0 & 0 & 3 & 0 & 54 & 0 & 39 & 0 & 8 & 167 \\
\hline \multirow[t]{3}{*}{ Plant no. 4} & 6 & 3697 & 200 & 3 & 0 & 22 & 0 & 18 & 18 & 0 & 56 & 6 & 0 & 11 & 12 & 146 \\
\hline & 7 & 3698 & 200 & 30 & 0 & 44 & 0 & 20 & 18 & 0 & 282 & 24 & 0 & 9 & 24 & 451 \\
\hline & 8 & 15795 & 300 & 27 & 0 & 24 & 0 & 20 & 18 & 0 & 111 & 12 & 0 & 15 & 12 & 239 \\
\hline \multirow[t]{2}{*}{ Plant no. 6} & 1 & 24850 & 500 & 3,705 & 3,719 & 3,055 & 988 & 862 & 5,936 & 3,956 & 285 & 316 & 942 & 0 & 381 & 24,145 \\
\hline & 2 & 24851 & 500 & 3,875 & 2,120 & 1,413 & 3,366 & 3,161 & 5,668 & 5,464 & 1,224 & 1,193 & 5,236 & 2,995 & 1,719 & 37,434 \\
\hline \multirow[t]{2}{*}{ Plant no. 7} & 1 & 33775 & 500 & 4,205 & 5,196 & 5,940 & 4,379 & 3,099 & 6,139 & 5,529 & 6,429 & 4,494 & 4,715 & 3,870 & 3,884 & 57,879 \\
\hline & 2 & 93794 & 500 & 5,116 & 4,244 & 5,737 & 3,953 & 4,792 & 6,399 & 4,189 & 9,466 & 6,703 & 3,178 & 4,864 & 3,809 & 62,450 \\
\hline Plant no. 8 & 1 & 71873 & 500 & 0 & 0 & 21 & 0 & 0 & 36 & 5 & 14 & 13 & 0 & 12 & 18 & 119 \\
\hline Plant no. 9 & 1 & 76772 & 500 & 0 & 0 & 22 & 0 & 0 & 541 & 1,214 & 2,002 & 2,508 & 2,661 & 2,132 & 2,624 & 13,704 \\
\hline Plant no. 12 & 1 & 97501 & 500 & 2,567 & 1,218 & 3,449 & 5,165 & 7,969 & 8,737 & 15,244 & 10,984 & 9,694 & 5,541 & 5,000 & 3,960 & 79,528 \\
\hline Plant no. 15 & 1 & 97502 & 500 & 4,698 & 3,821 & 3,758 & 6,172 & 9,489 & 9,483 & 15,304 & 9,768 & 6,191 & 3,745 & 2,246 & 3,973 & 78,648 \\
\hline Subtotal $^{c}$ & & & 4,867 & 24,256 & 20,318 & 23,518 & 24,023 & 29,430 & 42,996 & 50,905 & 40,675 & 31,154 & 26,057 & 21,154 & 20,424 & 354,910 \\
\hline
\end{tabular}

SUFFOLK COUNTY WATER AUTHORITY--MATTITUCK ZONE

\begin{tabular}{|c|c|c|c|c|c|c|c|c|c|c|c|c|c|c|c|c|}
\hline \multirow[t]{3}{*}{ Inlet Drive } & 1 & 6513 & 200 & 755 & 798 & 594 & 483 & 0 & 0 & 0 & 0 & 0 & 0 & 0 & 0 & 2,630 \\
\hline & $1 \mathrm{~A}$ & 105669 & 200 & 0 & 0 & 0 & 0 & 0 & 0 & 331 & 1,238 & 1,101 & 2,048 & 555 & 1,222 & 6,495 \\
\hline & 2 & 17835 & 200 & 0 & 11 & 22 & 26 & 6 & 17 & 217 & 15 & 29 & 0 & 66 & 15 & 424 \\
\hline Sunset Dr. & 1 & 94138 & 130 & 702 & 545 & 473 & 563 & 1,485 & 3,362 & 3,740 & 1,889 & 1,374 & 122 & 941 & 324 & 15,520 \\
\hline Subtotal $^{\mathrm{c}}$ & & & 730 & 1,457 & 1,354 & 1,089 & 1,072 & 1,491 & 3,379 & 4,288 & 3,142 & 2,504 & 2,170 & 1,562 & 1,561 & 25,069 \\
\hline
\end{tabular}

SUFFOLK COUNTY WATER AUTHORITY--SOUTHOLD ZONE ${ }^{b}$

Main

\begin{tabular}{|c|c|c|c|c|c|c|c|c|c|c|c|c|c|c|c|c|}
\hline Bayview & 1 & 89754 & 30 & -- & -- & -- & -- & -- & -- & -- & 7 & 36 & 19 & 27 & 37 & 126 \\
\hline & 2 & 94274 & 30 & -- & -- & -- & -- & -- & -- & -- & 72 & 27 & 14 & 23 & 44 & 180 \\
\hline & 3 & 89756 & 25 & -- & -- & -- & -- & -- & -- & -- & 23 & 16 & 27 & 47 & 0 & 113 \\
\hline Subtotal $^{\mathrm{c}}$ & & & 85 & -- & -- & -- & -- & -- & -- & -- & 102 & 79 & 60 & 97 & 81 & 419 \\
\hline TOTAL $^{\mathrm{c}}$ & & & 5,682 & 25,713 & 21,672 & 24,607 & 25,095 & 30,921 & 46,375 & 55,193 & 43,919 & 33,737 & 28,287 & 22,813 & 22,066 & 380,398 \\
\hline
\end{tabular}

TOTAL PUMPAGE, BY SEASON

\begin{tabular}{|c|c|c|c|c|c|}
\hline Greenport Water District- & May through October & 221,217 & SCWA--Southold Zone ${ }^{\mathrm{b}}$ - & May through October & 241 \\
\hline & November through April & 133,693 & & November through April & 178 \\
\hline & Subtotal $^{\mathrm{c}}$ & 354,910 & & Subtotal & 419 \\
\hline SCWA--Mattituck Zone- & May through October & 16,974 & & & \\
\hline & November through April & 8,095 & & & \\
\hline & Subtotal & 25,069 & & & \\
\hline
\end{tabular}

\footnotetext{
${ }^{a}$ Prefix S for Suffolk County is omitted.
}

${ }^{\text {b }}$ Pumpage subtotals for Suffolk County Water Authority--Southold zone include only 5 months of pumpage data.

${ }^{\mathrm{c}}$ Total may not equal the sum of values because of rounding to significant digits. 
Appendix 2.. (continued) Estimated 1994 public-supply pumpage on the North Fork, Suffolk County, N.Y., by water-supply district [gal/min, gallons per minute; $\mathrm{ft}^{3} / \mathrm{s}$, cubic feet per second]

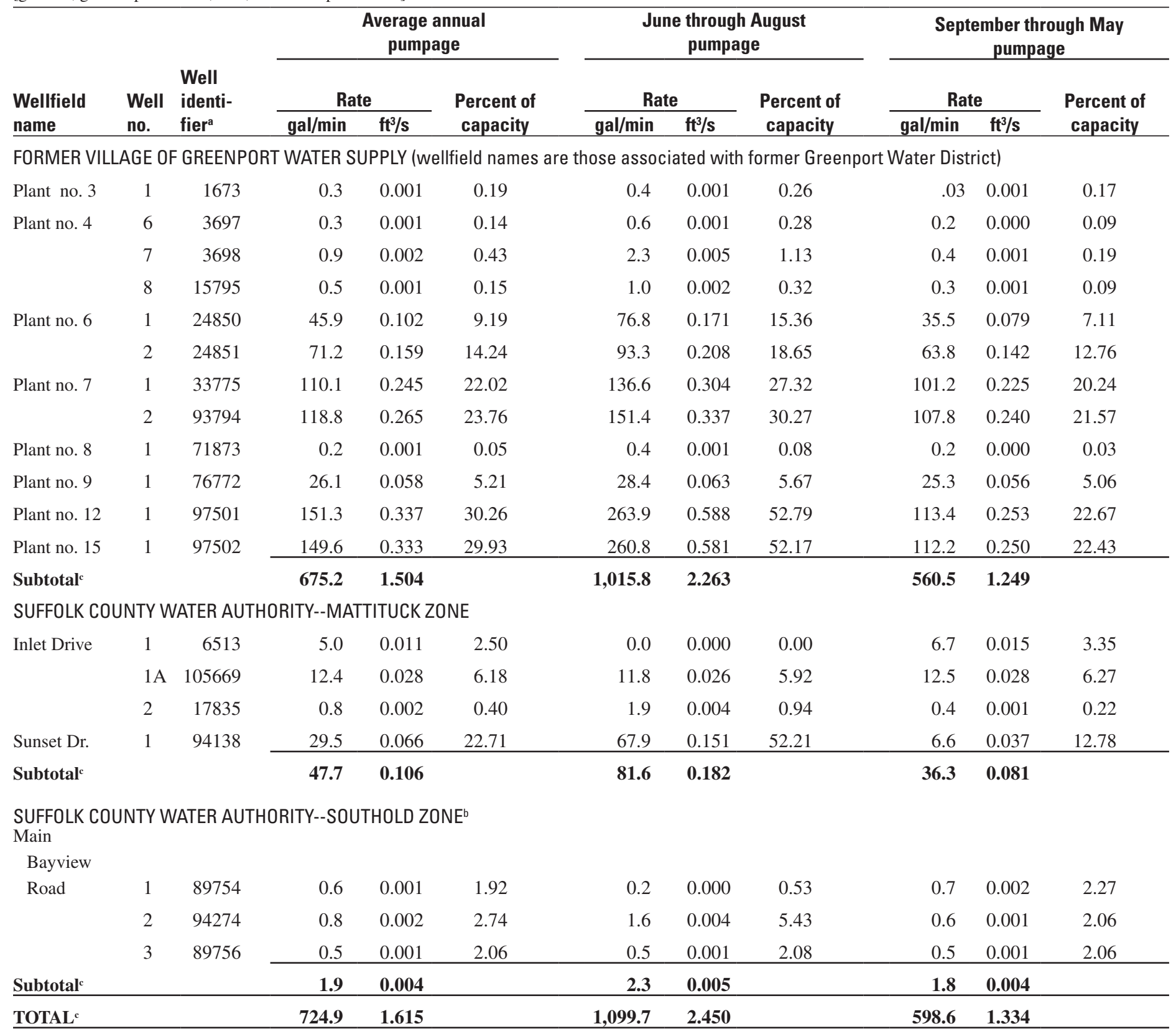


Appendix 3. 1998 pumpage by public water-supply districts on the North Fork, Suffolk County, N.Y.

[Wellfield locations are shown in fig. 3. cap., capacity; \%, percent; gal $/ \mathrm{min}$, gallons per minute; $\mathrm{ft}^{3} / \mathrm{s}$, cubic feet per second]

\begin{tabular}{|c|c|c|c|c|c|c|c|c|c|c|c|c|c|c|c|c|}
\hline \multirow{2}{*}{$\begin{array}{l}\text { Wellfield } \\
\text { name }\end{array}$} & \multirow{2}{*}{$\begin{array}{l}\text { Well } \\
\text { no. }\end{array}$} & \multirow{2}{*}{$\begin{array}{c}\text { Well } \\
\text { identifier }\end{array}$} & \multirow{2}{*}{$\begin{array}{l}\text { Well cap. } \\
\text { (gal/min) }\end{array}$} & \multicolumn{12}{|c|}{ Monthly pumpage (thousands of gallons) } & \multirow[b]{2}{*}{ Total } \\
\hline & & & & Jan & Feb & Mar & Apr & May & Jun & Jul & Aug & Sep & Oct & Nov & Dec & \\
\hline \multicolumn{17}{|c|}{ SUFFOLK COUNTY WATER AUTHORITY - MATTITUCK ZONE } \\
\hline \multirow[t]{2}{*}{ Inlet Drive } & $1 \mathrm{~A}$ & S-105669 & 200 & 831 & 436 & 402 & 863 & 417 & 974 & 2,332 & 1,953 & 1,399 & 1,074 & 962 & 505 & 12,147 \\
\hline & $2 \mathrm{~A}$ & S-108347 & 200 & 189 & 386 & 440 & 301 & 1,207 & 1,240 & 1,708 & 1,653 & 1,279 & 1,100 & 936 & 465 & 10,904 \\
\hline \multirow[t]{2}{*}{ Laurel Lake } & 1 & S-101755 & 250 & 39 & 39 & 20 & 58 & 17 & 33 & 34 & 17 & 49 & 16 & 16 & 16 & 352 \\
\hline & 2 & S-106415 & 250 & 911 & 771 & 1,030 & 1,572 & 1,483 & 1,997 & 2,736 & 2,793 & 1,691 & 994 & 844 & 1,124 & 17,948 \\
\hline Sunset Drive & 1 & S-94138 & 130 & 18 & 18 & 0 & 0 & 946 & 25 & 170 & 732 & 804 & 425 & 226 & 54 & 3,417 \\
\hline \multicolumn{3}{|l|}{ Subtotal $^{\mathrm{a}}$} & 1,030 & 1,988 & 1,650 & 1,892 & 2,794 & 4,070 & 4,269 & 6,980 & 7,148 & 5,222 & 3,608 & 2,985 & 2,164 & 44,768 \\
\hline \multicolumn{17}{|c|}{$\begin{array}{l}\text { SUFFOLK COUNTY WATER AUTHORITY - SOUTHOLD ZONE } \\
\text { Ackerly }\end{array}$} \\
\hline Pond & 1 & S-33775 & 340 & 346 & 764 & 507 & 510 & 2,366 & 2,356 & 5,447 & 2,734 & 1,071 & 0 & 0 & 0 & 16,101 \\
\hline Brecknock & 2 & S-93794 & 500 & 207 & 592 & 1,175 & 1,869 & 72 & 0 & 1,047 & 6,887 & 2,366 & 2,815 & 2,746 & 3,187 & 22,963 \\
\hline $\begin{array}{l}\text { Hall } \\
\text { Kenneys }\end{array}$ & 1 & S-76772 & 200 & 3,495 & 3,278 & 3,180 & 2,562 & 3,282 & 3,168 & 3,132 & 2,946 & 1,770 & 2,568 & 2,922 & 2,944 & 35,247 \\
\hline \multirow{2}{*}{\multicolumn{17}{|c|}{$\begin{array}{l}\text { Main } \\
\text { Bayview }\end{array}$}} \\
\hline & & & & & & & & & & & & & & & & 736 \\
\hline \multirow{2}{*}{ Road. } & 2 & S-94274 & 30 & 12 & 9 & 15 & 3 & 18 & 20 & 24 & 69 & 114 & 32 & 12 & 63 & 391 \\
\hline & 3 & S-89756 & 25 & 0 & 4 & 38 & 1 & 3 & 3 & 2 & 27 & 126 & 6 & 2 & 61 & 273 \\
\hline $\begin{array}{l}\text { Middle Road } \\
\text { Mill Lane }\end{array}$ & 1 & S-97502 & 500 & 8,012 & 5,156 & 7,512 & 7,650 & 10,119 & 12,286 & 13,138 & 11,431 & 13,819 & 10,131 & 5,845 & 5,408 & 110,507 \\
\hline \multirow[t]{2}{*}{ (Peconic) } & 1 & S-103522 & 300 & 0 & 0 & 0 & 0 & 0 & 594 & 377 & 450 & 450 & 923 & 393 & 512 & 3,699 \\
\hline & 2 & S-103523 & 300 & 0 & 0 & 0 & 0 & 0 & 260 & 363 & 320 & 1,067 & 796 & 641 & 368 & 3,815 \\
\hline \multirow[t]{2}{*}{ North Road } & 1 & S-24850 & 500 & 141 & 443 & 543 & 533 & 1,893 & 2,523 & 4,196 & 4,366 & 1,830 & 818 & 831 & 968 & 19,084 \\
\hline & 3 & S-83475 & 425 & 23 & 89 & 1,222 & 622 & 0 & 0 & 29 & 5,405 & 2,007 & 2,059 & 1,090 & 645 & 13,191 \\
\hline \multicolumn{3}{|l|}{ Subtotal $^{\mathbf{a}}$} & 3,650 & 21,240 & 18,017 & 21,400 & 21,652 & 28,923 & 32,215 & 44,444 & 47,789 & 35,905 & 29,640 & 24,903 & 23,875 & 350,004 \\
\hline \multicolumn{3}{|l|}{ TOTAL $^{\mathrm{a}}$} & 4,735 & 23,471 & 19,873 & 23,524 & 24,697 & 33,453 & 36,930 & 52,091 & $\mathbf{5 5 , 7 7 3}$ & 41,723 & 33,737 & 28,253 & 26,338 & 399,861 \\
\hline \multicolumn{16}{|c|}{ Suffolk County Water Authority - Mattituck Zone May through October } & 31,296 \\
\hline \multicolumn{16}{|c|}{ Suffolk County Water Authority - Mattituck Zone November through April } & 13,472 \\
\hline \multicolumn{16}{|c|}{ Suffolk County Water Authority - Mattituck Zone total } & 44,768 \\
\hline
\end{tabular}


Appendix 3. (Continued) 1998 pumpage by public water-supply districts on the North Fork, Suffolk County, N.Y.

\begin{tabular}{|c|c|c|c|c|c|c|c|c|c|c|c|}
\hline \multirow{3}{*}{$\begin{array}{c}\text { Wellfield } \\
\text { name }\end{array}$} & \multirow{3}{*}{$\begin{array}{c}\text { Well } \\
\text { no. }\end{array}$} & \multirow{3}{*}{$\begin{array}{c}\text { Well } \\
\text { identifier }\end{array}$} & \multicolumn{3}{|c|}{ Average annual pumpage } & \multicolumn{3}{|c|}{ June through August } & \multicolumn{3}{|c|}{ September through May } \\
\hline & & & \multicolumn{2}{|c|}{ Rate } & \multirow[b]{2}{*}{$\%$ of cap. } & \multicolumn{2}{|c|}{ Rate } & \multirow[b]{2}{*}{$\%$ of cap. } & \multicolumn{2}{|c|}{ Rate } & \multirow[b]{2}{*}{$\%$ of cap. } \\
\hline & & & gal/min & $\mathrm{ft}^{3} / \mathrm{s}$ & & gal/min & $\mathrm{ft}^{3} / \mathrm{s}$ & & gal/min & $\mathrm{ft}^{3} / \mathrm{s}$ & \\
\hline \multicolumn{12}{|c|}{ SUFFOLK COUNTY WATER AUTHORITY - MATTITUCK ZONE } \\
\hline \multirow[t]{2}{*}{ Inlet Drive } & $1 \mathrm{~A}$ & S-105669 & 23.1 & 0.051 & 11.56 & 39.7 & 0.088 & 19.85 & 17.5 & 0.039 & 8.76 \\
\hline & $2 \mathrm{~A}$ & S-108347 & 20.7 & 0.046 & 10.37 & 34.7 & 0.077 & 17.37 & 16.0 & 0.036 & 8.02 \\
\hline \multirow[t]{2}{*}{ Laurel Lake } & 1 & S-101755 & 0.7 & 0.001 & 0.27 & 0.6 & 0.001 & 0.25 & 0.7 & 0.002 & 0.27 \\
\hline & 2 & S-106415 & 34.1 & 0.076 & 13.66 & 56.8 & 0.127 & 22.73 & 26.5 & 0.059 & 10.60 \\
\hline Sunset Drive & 1 & S-94138 & 6.5 & 0.014 & 5.00 & 7.0 & 0.016 & 5.38 & 6.3 & 0.014 & 4.87 \\
\hline Subtotal $^{\mathrm{a}}$ & & & 85.2 & 0.190 & & 138.9 & 0.309 & 13.48 & 67.1 & 0.149 & \\
\hline \multicolumn{12}{|c|}{ SUFFOLK COUNTY WATER AUTHORITY - SOUTHOLD ZONE } \\
\hline Ackerly Pond & 1 & S-33775 & 30.6 & 0.068 & 9.01 & 79.5 & 0.177 & 23.39 & 14.2 & 0.032 & 4.16 \\
\hline Brecknock & 2 & S-93794 & 43.7 & 0.097 & 8.74 & 59.9 & 0.133 & 11.98 & 38.2 & 0.085 & 7.65 \\
\hline $\begin{array}{c}\text { Hall } \\
\text { Kenneys }\end{array}$ & 1 & S-76772 & 67.1 & 0.149 & 33.53 & 69.8 & 0.155 & 34.90 & 66.1 & 0.147 & 33.07 \\
\hline $\begin{array}{l}\text { Road } \\
\text { Main }\end{array}$ & 1 & S-97501 & 235.9 & 0.526 & 47.18 & 305.3 & 0.680 & 61.06 & 212.5 & 0.474 & 42.51 \\
\hline \multirow[t]{3}{*}{$\begin{array}{l}\text { Bayview } \\
\text { Rd. }\end{array}$} & 1 & S-89754 & 1.4 & 0.003 & 4.67 & 3.0 & 0.007 & 10.17 & 0.8 & 0.002 & 2.82 \\
\hline & 2 & S-94274 & 0.7 & 0.002 & 2.48 & 0.9 & 0.002 & 2.84 & 0.7 & 0.002 & 2.36 \\
\hline & 3 & S-89756 & 0.5 & 0.001 & 2.08 & 0.2 & 0.001 & 0.97 & 0.6 & 0.001 & 2.46 \\
\hline $\begin{array}{l}\text { Middle Road } \\
\text { Mill Lane }\end{array}$ & 1 & S-97502 & 210.2 & 0.468 & 42.05 & 278.2 & 0.620 & 55.64 & 187.4 & 0.417 & 37.47 \\
\hline \multirow[t]{2}{*}{ (Peconic) } & 1 & S-103522 & 7.0 & 0.016 & 2.35 & 10.7 & 0.024 & 3.58 & 5.8 & 0.013 & 1.93 \\
\hline & 2 & S-103523 & 7.3 & 0.016 & 2.42 & 7.1 & 0.016 & 2.37 & 7.3 & 0.016 & 2.44 \\
\hline \multirow[t]{2}{*}{ North Road } & 1 & S-24850 & 36.3 & 0.081 & 7.26 & 83.7 & 0.186 & 16.73 & 20.3 & 0.045 & 4.07 \\
\hline & 3 & S-83475 & 25.1 & 0.056 & 5.91 & 41.0 & 0.091 & 9.65 & 19.7 & 0.044 & 4.64 \\
\hline Subtotal $^{\mathrm{a}}$ & & & 665.9 & 1.484 & & 939.4 & 2.093 & & $\mathbf{5 7 3 . 8}$ & 1.278 & \\
\hline TOTAL $^{\mathbf{a}}$ & & & 760.8 & 1.695 & & $1,092.9$ & 2.435 & & 648.8 & 1.446 & \\
\hline
\end{tabular}

a Total may not equal the sum of values because of rounding to significant digits. 
Appendix 4. Reported and estimated annual 1993-95 pumpage by commercial-supply wells on the North Fork, Suffolk County, N.Y.

[gal/min, gallons per minute; $\mathrm{ft}^{3} / \mathrm{s}$, cubic feet per second; --, no data reported]

\begin{tabular}{|c|c|c|c|c|c|c|c|c|c|}
\hline \multirow{3}{*}{$\begin{array}{c}\text { Well } \\
\text { Identifier }\end{array}$} & \multirow[b]{3}{*}{ Well use } & \multirow{3}{*}{$\begin{array}{c}\text { Well } \\
\text { capacity } \\
\text { (gal/min) }\end{array}$} & \multirow{2}{*}{\multicolumn{3}{|c|}{ Total pumpage (gallons) }} & \multicolumn{4}{|c|}{ 1993-95 mean annual pumpage } \\
\hline & & & & & & \multirow{2}{*}{$\begin{array}{c}\text { Total } \\
\text { (gallons) }\end{array}$} & \multicolumn{2}{|c|}{ Flow rate } & \multirow{2}{*}{$\begin{array}{c}\text { Percent of } \\
\text { capacity }\end{array}$} \\
\hline & & & 1993 & 1994 & 1995 & & $\mathrm{gal} / \mathrm{min}$ & $\mathrm{ft}^{3} / \mathrm{s}$ & \\
\hline \multicolumn{10}{|c|}{ REPORTED PUMPAGE } \\
\hline S-31448 & Irrigation & 600 & $21,126,000$ & $21,989,000$ & $14,332,000$ & $19,149,000$ & 36.4 & 0.081 & 6.07 \\
\hline S-52086 & Industrial & 65 & $1,727,000$ & $1,814,000$ & $1,855,000$ & $1,798,667$ & 3.4 & 0.008 & 5.26 \\
\hline S-93628 & Domestic & 80 & -- & 0 & $2,611,000$ & $1,305,500$ & 2.5 & 0.006 & 3.10 \\
\hline S-94491 & Irrigation & 60 & $2,353,000$ & $10,189,000$ & $1,178,000$ & $4,573,333$ & 8.7 & 0.019 & 14.50 \\
\hline$\underline{\text { Subtotal }}^{\mathrm{a}}$ & & 805 & $25,206,000$ & $33,992,000$ & $19,976,000$ & $26,826,500$ & 51.0 & 0.114 & \\
\hline \multicolumn{10}{|c|}{ ESTIMATED PUMPAGE } \\
\hline S-11362 & Irrigation & 60 & -- & -- & -- & $1,999,491$ & 3.8 & 0.008 & 6.34 \\
\hline S-11699 & Domestic & 25 & -- & -- & -- & 833,121 & 1.6 & 0.004 & 6.34 \\
\hline S-26049 & Domestic & 20 & -- & -- & -- & 666,497 & 1.3 & 0.003 & 6.34 \\
\hline S-33990 & Domestic & 30 & -- & -- & -- & 999,745 & 1.9 & 0.004 & 6.34 \\
\hline S-36799 & General & 200 & -- & -- & -- & $6,664,969$ & 12.7 & 0.028 & 6.34 \\
\hline S-45809 & Domestic & 20 & -- & -- & -- & 666,497 & 1.3 & 0.003 & 6.34 \\
\hline S-45810 & Domestic & 20 & -- & -- & -- & 666,497 & 1.3 & 0.003 & 6.34 \\
\hline S-45811 & Domestic & 20 & -- & -- & -- & 666,497 & 1.3 & 0.003 & 6.34 \\
\hline S-45812 & Domestic & 20 & -- & -- & -- & 666,497 & 1.3 & 0.003 & 6.34 \\
\hline S-84076 & Domestic & 20 & -- & -- & -- & 666,497 & 1.3 & 0.003 & 6.34 \\
\hline S-98991 & Irrigation & 500 & -- & -- & -- & $16,662,422$ & 31.7 & 0.071 & 6.34 \\
\hline S-101947 & Domestic & 20 & -- & -- & -- & 666,497 & 1.3 & 0.003 & 6.34 \\
\hline$\underline{\text { Subtotal }}^{\mathrm{a}}$ & & 955 & -- & -- & -- & $\mathbf{3 1 , 8 2 5 , 2 2 7}$ & 60.6 & 0.135 & \\
\hline TOTAL $^{a}$ & & 1,760 & $25,206,000$ & $33,992,000$ & $19,976,000$ & $58,651,727$ & 111.6 & 0.249 & \\
\hline
\end{tabular}

${ }^{a}$ Total may not equal the sum of values because of rounding to significant digits. 
Appendix 5. Annual, seasonal, and long-term precipitation at Bridgehampton, Greenport, and Riverhead, Suffolk County, N.Y., and corresponding recharge from land surface and lakes, 1955-99

[Precipitation values are in inches. Boldface values are means for multiple years. --, no data available. Locations are shown in fig. 1.]

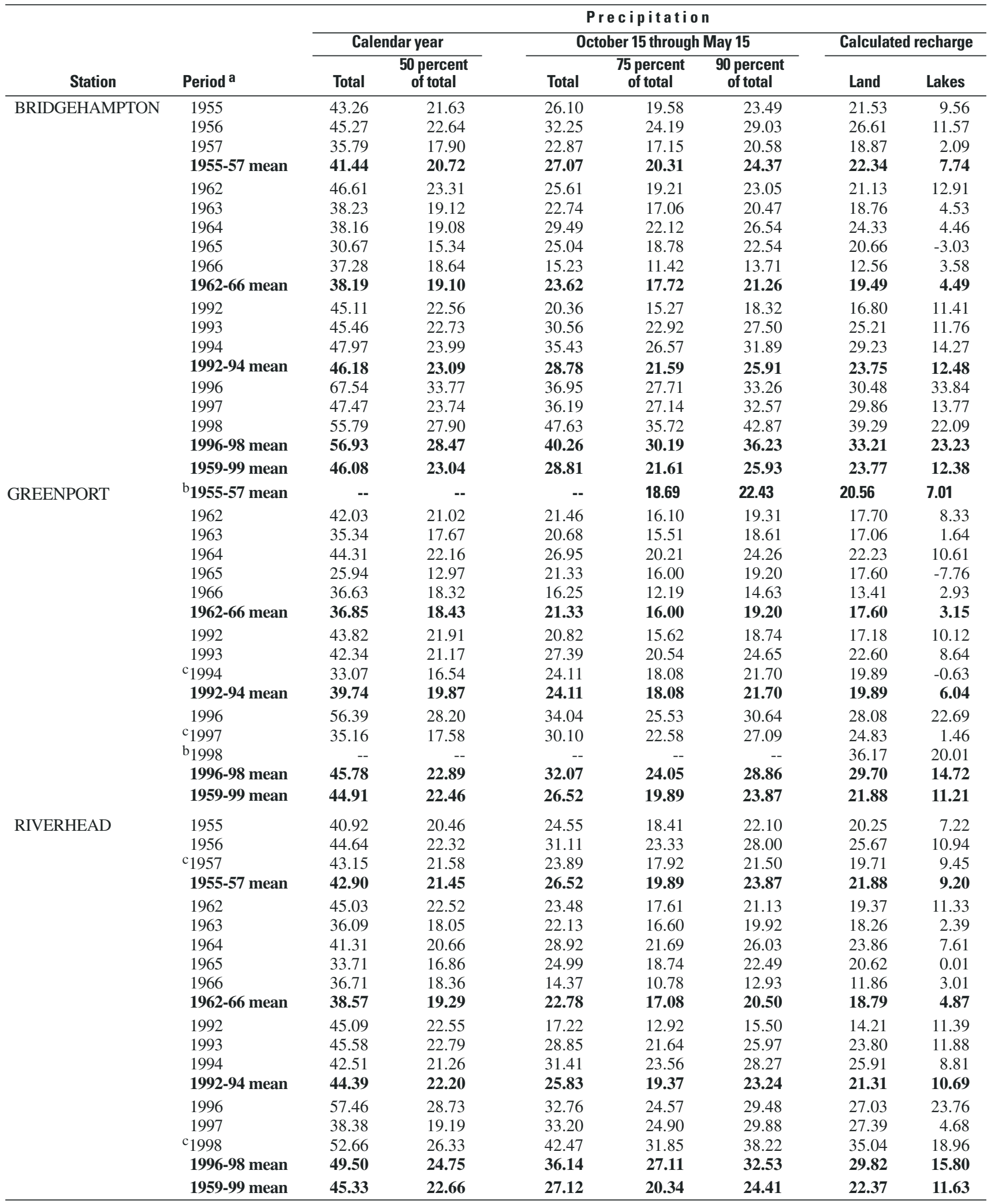

${ }^{a}$ Long-term precipitation data incomplete for 1 or more years; data for those years were not used to compute long-term mean value.

b Greenport recharge data for 1955-57 and 1998 estimated from Bridgehampton records and from the ratio of 1959-99 values.

c Precipitation data for the following years and stations were unavailable; annual values for the stated months were estimated

from Bridgehampton records: Greenport - September 1994 and October 1997. Riverhead - September 1957 and April 1998. 
Appendix 6. Modeled public water-supply pumpage and return-flow rates for 1957, 1994, 1998, and 2020 on the North Fork, Suffolk County, N.Y.

[est., estimated. SWCA, Suffolk County Water Authority. --, no data available]

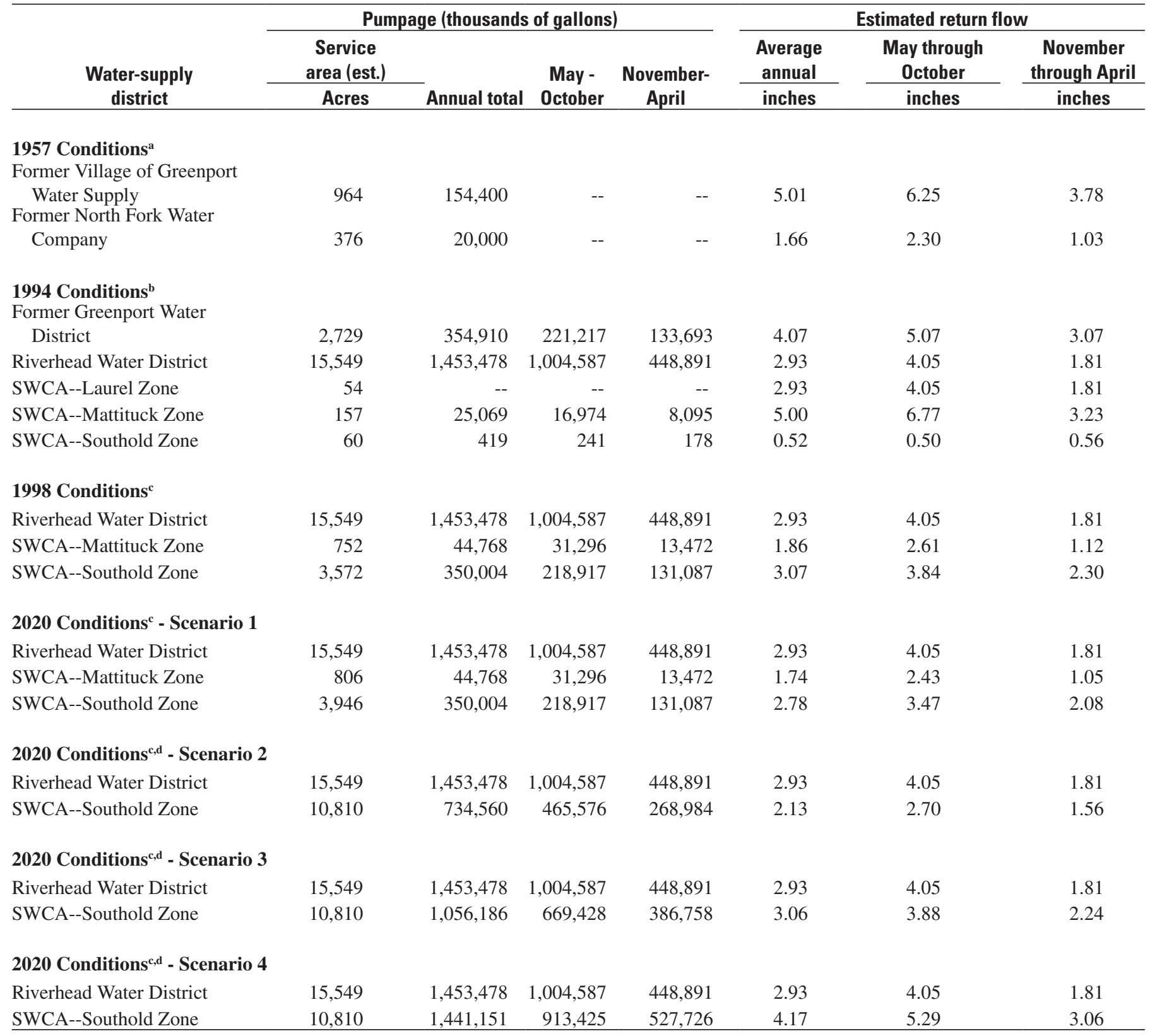

${ }^{\text {a }}$ Pumpage and estimated 1957 monthly return flow for former Village of Greenport Water Supply excludes 5,200,000 gallons pumped for irrigation. Estimated 1957 return flows for former Village of Greenport Water Supply are based on ratio of May through October to 1994 annual total pumgage by former Greenport Water District.

${ }^{\mathrm{b}}$ Pumpage and estimated monthly return flows in 1994 for SWCA - Laurel Zone are from Riverhead Water District.

Estimated monthly return-flow rates in 1994 for SWCA - Southold zone are estimated from 5 months of pumpage data.

c 1998 and 2020 pumpage and estimated monthly return-flow rates for Riverhead Water District are from 1994 data for this system.

${ }^{\mathrm{d}}$ Estimated monthly return flow for SWCA 2020 scenarios 2-4 are based on ratio of May through October

to 1998 annual total pumgage for this system. 
Appendix 7. Pumpage at present, planned, and proposed public water-supply wellfields on the North Fork, Suffolk County, N.Y, Scenario 2 [Well identifier between 190000 and 199999 denotes planned well; identifier with number greater than 200000 denotes proposed well. Well-identifier prefix "S" is omitted.]

\begin{tabular}{|c|c|c|c|c|c|c|c|c|c|c|c|c|c|}
\hline \multirow[b]{4}{*}{ Wellfield name } & \multirow{4}{*}{$\begin{array}{c}\text { Well } \\
\text { no. }\end{array}$} & \multirow{4}{*}{$\begin{array}{c}\text { Well } \\
\text { identifier }\end{array}$} & \multirow{4}{*}{$\begin{array}{c}\text { Well } \\
\text { capacity } \\
\text { (gal/min) }\end{array}$} & \multirow{4}{*}{$\begin{array}{c}\text { Annual } \\
\text { total } \\
\text { pumpage } \\
\left(\text { gal } \times 10^{3}\right)\end{array}$} & \multicolumn{9}{|c|}{ Monthly pumping rate } \\
\hline & & & & & \multicolumn{3}{|c|}{ Average annual } & \multicolumn{3}{|c|}{ June through August } & \multicolumn{3}{|c|}{ September through May } \\
\hline & & & & & \multicolumn{2}{|c|}{ Flow rate } & \multirow{2}{*}{$\begin{array}{l}\text { Percent } \\
\text { of } \\
\text { capacity }\end{array}$} & \multicolumn{2}{|c|}{ Flow rate } & \multirow{2}{*}{$\begin{array}{l}\text { Percent } \\
\text { of } \\
\text { capacity }\end{array}$} & \multicolumn{2}{|c|}{ Flow rate } & \multirow{2}{*}{$\begin{array}{c}\text { Percent } \\
\text { of } \\
\text { capacity }\end{array}$} \\
\hline & & & & & gal/min & $\mathrm{ft}^{3} / \mathrm{s}$ & & $\mathrm{gal} / \mathrm{min}$ & $\mathrm{ft}^{3} / \mathrm{s}$ & & $\mathrm{gal} / \mathrm{min}$ & $\mathrm{ft}^{3} / \mathrm{s}$ & \\
\hline \multicolumn{14}{|c|}{ Scenario 2--Increase number of connections to 8,930, serving 67 percent of 13,313 housing units in 1998.} \\
\hline \multicolumn{14}{|c|}{ SUFFOLK COUNTY WATER AUTHORITY--SOUTHOLD ZONE } \\
\hline \multirow[t]{2}{*}{ Ackerly Pond } & 1 & 33775 & 340 & 28,281 & 53.8 & 0.120 & 15.83 & 77.5 & 0.173 & 22.79 & 45.9 & 0.102 & 13.50 \\
\hline & 2 & 93794 & 500 & 41,590 & 79.1 & 0.176 & 15.83 & 113.9 & 0.254 & 22.79 & 67.5 & 0.150 & 13.50 \\
\hline \multirow[t]{2}{*}{ Alvah's Lane } & 1 & 190001 & 50 & 4,159 & 7.9 & 0.018 & 15.83 & 11.4 & 0.025 & 22.79 & 6.8 & 0.015 & 13.50 \\
\hline & 2 & 190002 & 100 & 8,318 & 15.8 & 0.035 & 15.83 & 22.8 & 0.051 & 22.79 & 13.5 & 0.030 & 13.50 \\
\hline Brecknock Hall & 1 & 76772 & 200 & 16,636 & 31.7 & 0.071 & 15.83 & 45.6 & 0.102 & 22.79 & 27.0 & 0.060 & 13.50 \\
\hline \multirow[t]{2}{*}{ Inlet Drive } & $1 \mathrm{~A}$ & 105669 & 200 & 16,636 & 31.7 & 0.071 & 15.83 & 45.6 & 0.102 & 22.79 & 27.0 & 0.060 & 13.50 \\
\hline & $2 \mathrm{~A}$ & 108347 & 200 & 16,636 & 31.7 & 0.071 & 15.83 & 45.6 & 0.102 & 22.79 & 27.0 & 0.060 & 13.50 \\
\hline Island's End & 6 & 3697 & 200 & 16,636 & 31.7 & 0.071 & 15.83 & 45.6 & 0.102 & 22.79 & 27.0 & 0.060 & 13.50 \\
\hline & 7 & 3698 & 200 & 16,636 & 31.7 & 0.071 & 15.83 & 45.6 & 0.102 & 22.79 & 27.0 & 0.060 & 13.50 \\
\hline & 8 & 15795 & 300 & 24,954 & 47.5 & 0.106 & 15.83 & 68.4 & 0.152 & 22.79 & 40.5 & 0.090 & 13.50 \\
\hline Kenneys Road & 1 & 97501 & 500 & 41,590 & 79.1 & 0.176 & 15.83 & 113.9 & 0.254 & 22.79 & 67.5 & 0.150 & 13.50 \\
\hline Laurel Lake & 1 & 101755 & 250 & 20,795 & 39.6 & 0.088 & 15.83 & 57.0 & 0.127 & 22.79 & 33.8 & 0.075 & 13.50 \\
\hline & 2 & 106415 & 250 & 20,795 & 39.6 & 0.088 & 15.83 & 57.0 & 0.127 & 22.79 & 33.8 & 0.075 & 13.50 \\
\hline Main Bayview Road & 1 & 89754 & 30 & 2,495 & 4.7 & 0.011 & 15.83 & 6.8 & 0.015 & 22.79 & 4.1 & 0.009 & 13.50 \\
\hline & 2 & 94274 & 30 & 2,495 & 4.7 & 0.011 & 15.83 & 6.8 & 0.015 & 22.79 & 4.1 & 0.009 & 13.50 \\
\hline & 3 & 89756 & 25 & 2,079 & 4.0 & 0.009 & 15.83 & 5.7 & 0.013 & 22.79 & 3.4 & 0.008 & 13.50 \\
\hline Middle Road & 1 & 97502 & 500 & 41,590 & 79.1 & 0.176 & 15.83 & 113.9 & 0.254 & 22.79 & 67.5 & 0.150 & 13.50 \\
\hline Mill Lane (Peconic) & 1 & 103522 & 300 & 24,954 & 47.5 & 0.106 & 15.83 & 68.4 & 0.152 & 22.79 & 40.5 & 0.090 & 13.50 \\
\hline & 2 & 103523 & 300 & 24,954 & 47.5 & 0.106 & 15.83 & 68.4 & 0.152 & 22.79 & 40.5 & 0.090 & 13.50 \\
\hline Moore's Lane & 1 & 1673 & 167 & 13,891 & 26.4 & 0.059 & 15.83 & 38.1 & 0.085 & 22.79 & 22.6 & 0.050 & 13.50 \\
\hline & 2 & 1674 & 167 & 13,891 & 26.4 & 0.059 & 15.83 & 38.1 & 0.085 & 22.79 & 22.6 & 0.050 & 13.50 \\
\hline & 6 & 1678 & 167 & 13,891 & 26.4 & 0.059 & 15.83 & 38.1 & 0.085 & 22.79 & 22.6 & 0.050 & 13.50 \\
\hline North Road & 1 & 24850 & 500 & 41,590 & 79.1 & 0.176 & 15.83 & 113.9 & 0.254 & 22.79 & 67.5 & 0.150 & 13.50 \\
\hline & 2 & 24851 & 500 & 41,590 & 79.1 & 0.176 & 15.83 & 113.9 & 0.254 & 22.79 & 67.5 & 0.150 & 13.50 \\
\hline & 3 & 83475 & 425 & 35,351 & 67.3 & 0.150 & 15.83 & 96.9 & 0.216 & 22.79 & 57.4 & 0.128 & 13.50 \\
\hline North Road (Peconic) & 1 & 113387 & 150 & 12,477 & 23.7 & 0.053 & 15.83 & 34.2 & 0.076 & 22.79 & 20.3 & 0.045 & 13.50 \\
\hline Parcel number 1 & 1 & 200001 & 150 & 12,477 & 23.7 & 0.053 & 15.83 & 34.2 & 0.076 & 22.79 & 20.3 & 0.045 & 13.50 \\
\hline Parcel number 7 & 1 & 200007 & 150 & 12,477 & 23.7 & 0.053 & 15.83 & 34.2 & 0.076 & 22.79 & 20.3 & 0.045 & 13.50 \\
\hline Parcel number 10 & 1 & 200010 & 300 & 24,954 & 47.5 & 0.106 & 15.83 & 68.4 & 0.152 & 22.79 & 40.5 & 0.090 & 13.50 \\
\hline Parcel number 15 & 1 & 200015 & 150 & 12,477 & 23.7 & 0.053 & 15.83 & 34.2 & 0.076 & 22.79 & 20.3 & 0.045 & 13.50 \\
\hline Parcel number 16 & 1 & 200016 & 300 & 24,954 & 47.5 & 0.106 & 15.83 & 68.4 & 0.152 & 22.79 & 40.5 & 0.090 & 13.50 \\
\hline Rocky Point Road & 1 & 115103 & 50 & 4,159 & 7.9 & 0.018 & 15.83 & 11.4 & 0.025 & 22.79 & 6.8 & 0.015 & 13.50 \\
\hline South Harbor Road & 1 & 169 & 250 & 20,795 & 39.6 & 0.088 & 15.83 & 57.0 & 0.127 & 22.79 & 33.8 & 0.075 & 13.50 \\
\hline & 3 & 3045 & 250 & 20,795 & 39.6 & 0.088 & 15.83 & 57.0 & 0.127 & 22.79 & 33.8 & 0.075 & 13.50 \\
\hline & 4 & 4163 & 50 & 4,159 & 7.9 & 0.018 & 15.83 & 11.4 & 0.025 & 22.79 & 6.8 & 0.015 & 13.50 \\
\hline Sunset Drive & 1 & 94138 & 130 & 10,813 & 20.6 & 0.046 & 15.83 & 29.6 & 0.066 & 22.79 & 17.6 & 0.039 & 13.50 \\
\hline The Long Way & 1 & 71873 & 500 & 41,590 & 79.1 & 0.176 & 15.83 & 113.9 & 0.254 & 22.79 & 67.5 & 0.150 & 13.50 \\
\hline TOTAL ${ }^{a}$ & & & 8,831 & 734,560 & $1,397.6$ & 3.114 & & $2,012.5$ & 4.484 & & $1,192.6$ & 2.657 & \\
\hline
\end{tabular}

${ }^{a}$ Total may not equal the sum of values because of rounding to significant digits. 
Appendix 8. Pumpage at present, planned, and proposed public water-supply wellfields on the North Fork, Suffolk County, N.Y., Scenario 3

\begin{tabular}{|c|c|c|c|c|c|c|c|c|c|c|c|c|c|}
\hline \multirow[b]{4}{*}{ Wellfield name } & \multirow{4}{*}{$\begin{array}{c}\text { Well } \\
\text { no. }\end{array}$} & \multirow{4}{*}{$\begin{array}{c}\text { Well } \\
\text { identifier }\end{array}$} & \multirow{4}{*}{$\begin{array}{c}\text { Well } \\
\text { capacity } \\
\text { (gal/min) }\end{array}$} & \multirow{4}{*}{$\begin{array}{c}\text { Annual } \\
\text { total } \\
\text { pumpage } \\
\text { (gal } \times 10^{3} \text { ) }\end{array}$} & \multicolumn{9}{|c|}{ Monthly pumping rate } \\
\hline & & & & & \multicolumn{3}{|c|}{ Average annual } & \multicolumn{3}{|c|}{ June through August } & \multicolumn{3}{|c|}{ September through May } \\
\hline & & & & & \multicolumn{2}{|c|}{ Flow rate } & \multirow{2}{*}{$\begin{array}{l}\text { Percent } \\
\text { of capacity }\end{array}$} & \multicolumn{2}{|c|}{ Flow rate } & \multirow{2}{*}{$\begin{array}{c}\text { Percent } \\
\text { of capacity }\end{array}$} & \multicolumn{2}{|c|}{ Flow rate } & \multirow{2}{*}{$\begin{array}{c}\text { Percent } \\
\text { of capacity }\end{array}$} \\
\hline & & & & & gal/min & $\mathbf{f t}^{3} / \mathbf{s}$ & & $\mathrm{gal} / \mathrm{min}$ & $\mathrm{ft}^{3} / \mathrm{s}$ & & gal/min & $\mathrm{ft}^{3} / \mathbf{s}$ & \\
\hline \multicolumn{14}{|c|}{ Scenario 3--Increase number of connections to 12,840, serving 96 percent of 13,313 housing units in 1998.} \\
\hline \multicolumn{14}{|c|}{ SUFFOLK COUNTY WATER AUTHORITY—SOUTHOLD ZONE } \\
\hline \multirow[t]{2}{*}{ Ackerly Pond } & 1 & 33775 & 340 & 40,664 & 77.4 & 0.172 & 22.75 & 111.4 & 0.248 & 32.77 & 66.0 & 0.147 & 19.42 \\
\hline & 2 & 93794 & 500 & 59,800 & 113.8 & 0.253 & 22.75 & 163.8 & 0.365 & 32.77 & 97.1 & 0.216 & 19.42 \\
\hline \multirow[t]{2}{*}{ Alvah's Lane } & 1 & 190001 & 50 & 5,980 & 11.4 & 0.025 & 22.75 & 16.4 & 0.037 & 32.77 & 9.7 & 0.022 & 19.42 \\
\hline & 2 & 190002 & 100 & 11,960 & 22.8 & 0.051 & 22.75 & 32.8 & 0.073 & 32.77 & 19.4 & 0.043 & 19.42 \\
\hline Brecknock Hall & 1 & 76772 & 200 & 23,920 & 45.5 & 0.101 & 22.75 & 65.5 & 0.146 & 32.77 & 38.8 & 0.087 & 19.42 \\
\hline \multirow[t]{2}{*}{ Inlet Drive } & $1 \mathrm{~A}$ & 105669 & 200 & 23,920 & 45.5 & 0.101 & 22.75 & 65.5 & 0.146 & 32.77 & 38.8 & 0.087 & 19.42 \\
\hline & $2 \mathrm{~A}$ & 108347 & 200 & 23,920 & 45.5 & 0.101 & 22.75 & 65.5 & 0.146 & 32.77 & 38.8 & 0.087 & 19.42 \\
\hline \multirow[t]{3}{*}{ Island's End } & 6 & 3697 & 200 & 23,920 & 45.5 & 0.101 & 22.75 & 65.5 & 0.146 & 32.77 & 38.8 & 0.087 & 19.42 \\
\hline & 7 & 3698 & 200 & 23,920 & 45.5 & 0.101 & 22.75 & 65.5 & 0.146 & 32.77 & 38.8 & 0.087 & 19.42 \\
\hline & 8 & 15795 & 300 & 35,880 & 68.3 & 0.152 & 22.75 & 98.3 & 0.219 & 32.77 & 58.3 & 0.130 & 19.42 \\
\hline Kenneys Road & 1 & 97501 & 500 & 59,800 & 113.8 & 0.253 & 22.75 & 163.8 & 0.365 & 32.77 & 97.1 & 0.216 & 19.42 \\
\hline \multirow[t]{2}{*}{ Laurel Lake } & 1 & 101755 & 250 & 29,900 & 56.9 & 0.127 & 22.75 & 81.9 & 0.183 & 32.77 & 48.5 & 0.108 & 19.42 \\
\hline & 2 & 106415 & 250 & 29,900 & 56.9 & 0.127 & 22.75 & 81.9 & 0.183 & 32.77 & 48.5 & 0.108 & 19.42 \\
\hline \multirow[t]{3}{*}{ Main Bayview Road } & 1 & 89754 & 30 & 3,588 & 6.8 & 0.015 & 22.75 & 9.8 & 0.022 & 32.77 & 5.8 & 0.013 & 19.42 \\
\hline & 2 & 94274 & 30 & 3,588 & 6.8 & 0.015 & 22.75 & 9.8 & 0.022 & 32.77 & 5.8 & 0.013 & 19.42 \\
\hline & 3 & 89756 & 25 & 2,990 & 5.7 & 0.013 & 22.75 & 8.2 & 0.018 & 32.77 & 4.9 & 0.011 & 19.42 \\
\hline Middle Road & 1 & 97502 & 500 & 59,800 & 113.8 & 0.253 & 22.75 & 163.8 & 0.365 & 32.77 & 97.1 & 0.216 & 19.42 \\
\hline \multirow[t]{2}{*}{ Mill Lane (Peconic) } & 1 & 103522 & 300 & 35,880 & 68.3 & 0.152 & 22.75 & 98.3 & 0.219 & 32.77 & 58.3 & 0.130 & 19.42 \\
\hline & 2 & 103523 & 300 & 35,880 & 68.3 & 0.152 & 22.75 & 98.3 & 0.219 & 32.77 & 58.3 & 0.130 & 19.42 \\
\hline
\end{tabular}


Appendix 8. (Continued) Pumpage at present, planned, and proposed public water-supply wellfields on the North Fork, Suffolk County, N.Y., Scenario 3

\begin{tabular}{|c|c|c|c|c|c|c|c|c|c|c|c|c|c|}
\hline \multirow[b]{4}{*}{ Wellfield name } & \multirow{4}{*}{$\begin{array}{c}\text { Well } \\
\text { no. }\end{array}$} & \multirow{4}{*}{$\begin{array}{c}\text { Well } \\
\text { identifier }\end{array}$} & \multirow{4}{*}{$\begin{array}{c}\text { Well } \\
\text { capacity } \\
\text { (gal/min) }\end{array}$} & \multirow{4}{*}{$\begin{array}{c}\begin{array}{c}\text { Annual } \\
\text { total } \\
\text { pumpage } \\
\left(\text { gal } \times 10^{3}\right)\end{array} \\
\end{array}$} & \multicolumn{9}{|c|}{ Monthly pumping rate } \\
\hline & & & & & \multicolumn{3}{|c|}{ Average annual } & \multicolumn{3}{|c|}{ June through August } & \multicolumn{3}{|c|}{ September through May } \\
\hline & & & & & \multicolumn{2}{|c|}{ Flow rate } & \multirow{2}{*}{$\begin{array}{c}\text { Percent } \\
\text { of capacity }\end{array}$} & \multicolumn{2}{|c|}{ Flow rate } & \multirow{2}{*}{$\begin{array}{c}\text { Percent } \\
\text { of capacity }\end{array}$} & \multicolumn{2}{|c|}{ Flow rate } & \multirow{2}{*}{$\begin{array}{c}\text { Percent } \\
\text { of capacity }\end{array}$} \\
\hline & & & & & gal/min & $\mathrm{ft}^{3} / \mathrm{s}$ & & gal/min & $\mathrm{ft}^{3} / \mathrm{s}$ & & gal/min & $\mathrm{ft}^{3} / \mathrm{s}$ & \\
\hline \multirow[t]{3}{*}{ Moore's Lane } & 1 & 1673 & 167 & 19,973 & 38.0 & 0.085 & 22.75 & 54.7 & 0.122 & 32.77 & 32.4 & 0.072 & 19.42 \\
\hline & 2 & 1674 & 167 & 19,973 & 38.0 & 0.085 & 22.75 & 54.7 & 0.122 & 32.77 & 32.4 & 0.072 & 19.42 \\
\hline & 6 & 1678 & 167 & 19,973 & 38.0 & 0.085 & 22.75 & 54.7 & 0.122 & 32.77 & 32.4 & 0.072 & 19.42 \\
\hline \multirow[t]{3}{*}{ North Road } & 1 & 24850 & 500 & 59,800 & 113.8 & 0.253 & 22.75 & 163.8 & 0.365 & 32.77 & 97.1 & 0.216 & 19.42 \\
\hline & 2 & 24851 & 500 & 59,800 & 113.8 & 0.253 & 22.75 & 163.8 & 0.365 & 32.77 & 97.1 & 0.216 & 19.42 \\
\hline & 3 & 83475 & 425 & 50,830 & 96.7 & 0.215 & 22.75 & 139.3 & 0.310 & 32.77 & 82.5 & 0.184 & 19.42 \\
\hline North Road (Peconic) & 1 & 113387 & 150 & 17,940 & 34.1 & 0.076 & 22.75 & 49.2 & 0.110 & 32.77 & 29.1 & 0.065 & 19.42 \\
\hline Parcel number 1 & 1 & 200001 & 150 & 17,940 & 34.1 & 0.076 & 22.75 & 49.2 & 0.110 & 32.77 & 29.1 & 0.065 & 19.42 \\
\hline Parcel number 7 & 1 & 200007 & 150 & 17,940 & 34.1 & 0.076 & 22.75 & 49.2 & 0.110 & 32.77 & 29.1 & 0.065 & 19.42 \\
\hline Parcel number 10 & 1 & 200010 & 300 & 35,880 & 68.3 & 0.152 & 22.75 & 98.3 & 0.219 & 32.77 & 58.3 & 0.130 & 19.42 \\
\hline Parcel number 15 & 1 & 200015 & 150 & 17,940 & 34.1 & 0.076 & 22.75 & 49.2 & 0.110 & 32.77 & 29.1 & 0.065 & 19.42 \\
\hline Parcel number 16 & 1 & 200016 & 300 & 35,880 & 68.3 & 0.152 & 22.75 & 98.3 & 0.219 & 32.77 & 58.3 & 0.130 & 19.42 \\
\hline Rocky Point Road & 1 & 115103 & 50 & 5,980 & 11.4 & 0.025 & 22.75 & 16.4 & 0.037 & 32.77 & 9.7 & 0.022 & 19.42 \\
\hline \multirow[t]{3}{*}{ South Harbor Road } & 1 & 169 & 250 & 29,900 & 56.9 & 0.127 & 22.75 & 81.9 & 0.183 & 32.77 & 48.5 & 0.108 & 19.42 \\
\hline & 3 & 3045 & 250 & 29,900 & 56.9 & 0.127 & 22.75 & 81.9 & 0.183 & 32.77 & 48.5 & 0.108 & 19.42 \\
\hline & 4 & 4163 & 50 & 5,980 & 11.4 & 0.025 & 22.75 & 16.4 & 0.037 & 32.77 & 9.7 & 0.022 & 19.42 \\
\hline Sunset Drive & 1 & 94138 & 130 & 15,548 & 29.6 & 0.066 & 22.75 & 42.6 & 0.095 & 32.77 & 25.2 & 0.056 & 19.42 \\
\hline The Long Way & 1 & 71873 & 500 & 59,800 & 113.8 & 0.253 & 22.75 & 163.8 & 0.365 & 32.77 & 97.1 & 0.216 & 19.42 \\
\hline TOTAL ${ }^{\mathbf{a}}$ & & & 8,831 & $\mathbf{1 , 0 5 6 , 1 8 6}$ & $2,009.5$ & 4.477 & & $2,893.7$ & 6.447 & 32.77 & $1,714.8$ & 3.821 & \\
\hline
\end{tabular}

${ }^{a}$ Total may not equal the sum of values because of rounding to significant digits. 
Appendix 9. Pumpage at present, planned, and proposed public water-supply wellfields on the North Fork, Suffolk County, N.Y., Scenario 4

[Well identifier between 190000 and 199999 denotes planned well; identifier greater than 200000 denotes proposed well. Prefix S is omitted.]

\begin{tabular}{|c|c|c|c|c|c|c|c|c|c|c|c|c|c|}
\hline \multirow{4}{*}{$\begin{array}{c}\text { Wellfield } \\
\text { name }\end{array}$} & \multirow{4}{*}{$\begin{array}{c}\text { Well } \\
\text { no. }\end{array}$} & \multirow{4}{*}{$\begin{array}{c}\text { Well } \\
\text { identifier }\end{array}$} & \multirow{4}{*}{$\begin{array}{c}\text { Well } \\
\text { capacity } \\
\text { (gal/min) }\end{array}$} & \multirow{4}{*}{$\begin{array}{c}\text { Annual } \\
\text { total pumpage } \\
\left(\text { gal } \times 10^{3}\right)\end{array}$} & \multicolumn{9}{|c|}{ Monthly pumping rate } \\
\hline & & & & & \multicolumn{3}{|c|}{ Average annual } & \multicolumn{3}{|c|}{ May through August } & \multicolumn{3}{|c|}{ September through May } \\
\hline & & & & & \multicolumn{2}{|c|}{ Flow rate } & \multirow{2}{*}{$\begin{array}{c}\text { Percent of } \\
\text { capacity }\end{array}$} & \multicolumn{2}{|c|}{ Flow rate } & \multirow{2}{*}{$\begin{array}{c}\text { Percent of } \\
\text { capacity }\end{array}$} & \multicolumn{2}{|c|}{ Flow rate } & \multirow{2}{*}{$\begin{array}{c}\text { Percent of } \\
\text { capacity }\end{array}$} \\
\hline & & & & & gal/min & $\mathrm{ft}^{3} / \mathrm{s}$ & & gal/min & $\mathrm{ft} 3 / \mathrm{s}$ & & gal/min & $\mathrm{ft} 3 / \mathrm{s}$ & \\
\hline \multicolumn{14}{|c|}{ Scenario 4 (Scenario 3 plus 4,680 connections serving 62 percent of 7,590 additional housing units at saturation) } \\
\hline \multicolumn{14}{|c|}{ SUFFOLK COUNTY WATER AUTHORITY—SOUTHOLD ZONE } \\
\hline \multirow[t]{2}{*}{ Ackerly Pond } & 1 & 33775 & 340 & 55,485 & 105.6 & 0.235 & 31.05 & 152.0 & 0.339 & 44.71 & 90.1 & 0.201 & 26.49 \\
\hline & 2 & 93794 & 500 & 81,596 & 155.2 & 0.346 & 31.05 & 223.6 & 0.498 & 44.71 & 132.5 & 0.295 & 26.49 \\
\hline Alvah's Lane & 1 & 190001 & 50 & 8,160 & 15.5 & 0.035 & 31.05 & 22.4 & 0.050 & 44.71 & 13.2 & 0.030 & 26.49 \\
\hline Brecknock & 2 & 190002 & 100 & 16,319 & 31.0 & 0.069 & 31.05 & 44.7 & 0.100 & 44.71 & 26.5 & 0.059 & 26.49 \\
\hline Hall & 1 & 76772 & 200 & 32,638 & 62.1 & 0.138 & 31.05 & 89.4 & 0.199 & 44.71 & 53.0 & 0.118 & 26.49 \\
\hline \multirow[t]{2}{*}{ Inlet Drive } & $1 \mathrm{~A}$ & 105669 & 200 & 32,638 & 62.1 & 0.138 & 31.05 & 89.4 & 0.199 & 44.71 & 53.0 & 0.118 & 26.49 \\
\hline & $2 \mathrm{~A}$ & 108347 & 200 & 32,638 & 62.1 & 0.138 & 31.05 & 89.4 & 0.199 & 44.71 & 53.0 & 0.118 & 26.49 \\
\hline \multirow[t]{3}{*}{ Island's End } & 6 & 3697 & 200 & 32,638 & 62.1 & 0.138 & 31.05 & 89.4 & 0.199 & 44.71 & 53.0 & 0.118 & 26.49 \\
\hline & 7 & 3698 & 200 & 32,638 & 62.1 & 0.138 & 31.05 & 89.4 & 0.199 & 44.71 & 53.0 & 0.118 & 26.49 \\
\hline & 8 & 15795 & 300 & 48,958 & 93.1 & 0.208 & 31.05 & 134.1 & 0.299 & 44.71 & 79.5 & 0.177 & 26.49 \\
\hline $\begin{array}{c}\text { Kenneys } \\
\text { Road }\end{array}$ & 1 & 97501 & 500 & 81,596 & 155.2 & 0.346 & 31.05 & 223.6 & 0.498 & 44.71 & 132.5 & 0.295 & 26.49 \\
\hline Laurel Lake & 1 & 101755 & 250 & 40,798 & 77.6 & 0.173 & 31.05 & 111.8 & 0.249 & 44.71 & 66.2 & 0.148 & 26.49 \\
\hline \multirow{4}{*}{$\begin{array}{l}\text { Main } \\
\text { Bayview } \\
\text { Road }\end{array}$} & 2 & 106415 & 250 & 40,798 & 77.6 & 0.173 & 31.05 & 111.8 & 0.249 & 44.71 & 66.2 & 0.148 & 26.49 \\
\hline & 1 & 89754 & 30 & 4,896 & 9.3 & 0.021 & 31.05 & 13.4 & 0.030 & 44.71 & 7.9 & 0.018 & 26.49 \\
\hline & 2 & 94274 & 30 & 4,896 & 9.3 & 0.021 & 31.05 & 13.4 & 0.030 & 44.71 & 7.9 & 0.018 & 26.49 \\
\hline & 3 & 89756 & 25 & 4,080 & 7.8 & 0.017 & 31.05 & 11.2 & 0.025 & 44.71 & 6.6 & 0.015 & 26.49 \\
\hline \multirow{3}{*}{$\begin{array}{l}\text { Middle Road } \\
\text { Mill Lane } \\
\text { (Peconic) }\end{array}$} & 1 & 97502 & 500 & 81,596 & 155.2 & 0.346 & 31.05 & 223.6 & 0.498 & 44.71 & 132.5 & 0.295 & 26.49 \\
\hline & 1 & 103522 & 300 & 48,958 & 93.1 & 0.208 & 31.05 & 134.1 & 0.299 & 44.71 & 79.5 & 0.177 & 26.49 \\
\hline & 2 & 103523 & 300 & 48,958 & 93.1 & 0.208 & 31.05 & 134.1 & 0.299 & 44.71 & 79.5 & 0.177 & 26.49 \\
\hline
\end{tabular}

${ }^{a}$ Total may not equal the sum of values because of rounding to significant digits. 
Appendix 9. (continued) Pumpage at present, planned, and proposed public water-supply wellfields on the North Fork, Suffolk County, N.Y., Scenario 4

\begin{tabular}{|c|c|c|c|c|c|c|c|c|c|c|c|c|c|}
\hline \multirow{4}{*}{$\begin{array}{c}\text { Wellfield } \\
\text { name }\end{array}$} & \multirow{4}{*}{$\begin{array}{l}\text { Well } \\
\text { no. }\end{array}$} & \multirow{4}{*}{$\begin{array}{c}\begin{array}{c}\text { Well } \\
\text { identifier }\end{array} \\
\end{array}$} & \multirow{4}{*}{$\begin{array}{c}\text { Well } \\
\text { capacity } \\
\text { (gal/min) }\end{array}$} & \multirow{4}{*}{$\begin{array}{c}\text { Annual } \\
\text { total pumpage } \\
\left(\text { gal } \times 10^{3}\right)\end{array}$} & \multicolumn{9}{|c|}{ Monthly pumping rate } \\
\hline & & & & & \multicolumn{3}{|c|}{ Average annual } & \multicolumn{3}{|c|}{ May through August } & \multicolumn{3}{|c|}{ September through May } \\
\hline & & & & & \multicolumn{2}{|c|}{ Flow rate } & \multirow{2}{*}{$\begin{array}{l}\text { Percent of } \\
\text { capacity }\end{array}$} & \multicolumn{2}{|c|}{ Flow rate } & \multirow{2}{*}{$\begin{array}{c}\text { Percent of } \\
\text { capacity }\end{array}$} & \multicolumn{2}{|c|}{ Flow rate } & \multirow{2}{*}{$\begin{array}{c}\text { Percent of } \\
\text { capacity }\end{array}$} \\
\hline & & & & & $\mathrm{gal} / \mathrm{min}$ & $\mathrm{ft}^{3} / \mathrm{s}$ & & gal/min & $\mathrm{ft} 3 / \mathrm{s}$ & & gal/min & $\mathrm{ft} 3 / \mathrm{s}$ & \\
\hline \multirow[t]{3}{*}{ Moore's Lane } & 1 & 1673 & 167 & 27,253 & 51.9 & 0.116 & 31.05 & 74.7 & 0.166 & 44.71 & 44.2 & 0.099 & 26.49 \\
\hline & 2 & 1674 & 167 & 27,253 & 51.9 & 0.116 & 31.05 & 74.7 & 0.166 & 44.71 & 44.2 & 0.099 & 26.49 \\
\hline & 6 & 1678 & 167 & 27,253 & 51.9 & 0.116 & 31.05 & 74.7 & 0.166 & 44.71 & 44.2 & 0.099 & 26.49 \\
\hline \multirow[t]{3}{*}{ North Road } & 1 & 24850 & 500 & 81,596 & 155.2 & 0.346 & 31.05 & 223.6 & 0.498 & 44.71 & 132.5 & 0.295 & 26.49 \\
\hline & 2 & 24851 & 500 & 81,596 & 155.2 & 0.346 & 31.05 & 223.6 & 0.498 & 44.71 & 132.5 & 0.295 & 26.49 \\
\hline & 3 & 83475 & 425 & 69,357 & 132.0 & 0.294 & 31.05 & 190.0 & 0.423 & 44.71 & 112.6 & 0.251 & 26.49 \\
\hline $\begin{array}{l}\text { (Peconic) } \\
\text { Parcel }\end{array}$ & 1 & 113387 & 150 & 24,479 & 46.6 & 0.104 & 31.05 & 67.1 & 0.149 & 44.71 & 39.7 & 0.089 & 26.49 \\
\hline $\begin{array}{l}\text { number } 1 \\
\text { Parcel }\end{array}$ & 1 & 200001 & 150 & 24,479 & 46.6 & 0.104 & 31.05 & 67.1 & 0.149 & 44.71 & 39.7 & 0.089 & 26.49 \\
\hline number 7 & 1 & 200007 & 150 & 24,479 & 46.6 & 0.104 & 31.05 & 67.1 & 0.149 & 44.71 & 39.7 & 0.089 & 26.49 \\
\hline $\begin{array}{l}\text { Parcel } \\
\quad \text { number } 10\end{array}$ & 1 & 200010 & 300 & 48,958 & 93.1 & 0.208 & 31.05 & 134.1 & 0.299 & 44.71 & 79.5 & 0.177 & 26.49 \\
\hline $\begin{array}{l}\text { Parcel } \\
\quad \text { number } 15\end{array}$ & 1 & 200015 & 150 & 24,479 & 46.6 & 0.104 & 31.05 & 67.1 & 0.149 & 44.71 & 39.7 & 0.089 & 26.49 \\
\hline $\begin{array}{l}\text { Parcel } \\
\quad \text { number } 16\end{array}$ & 1 & 200016 & 300 & 48,958 & 93.1 & 0.208 & 31.05 & 134.1 & 0.299 & 44.71 & 79.5 & 0.177 & 26.49 \\
\hline $\begin{array}{l}\text { Rocky Point } \\
\text { Road }\end{array}$ & 1 & 115103 & 50 & 8,160 & 15.5 & 0.035 & 31.05 & 22.4 & 0.050 & 44.71 & 13.2 & 0.030 & 26.49 \\
\hline $\begin{array}{l}\text { South Harbor } \\
\text { Road }\end{array}$ & 1 & 169 & 250 & 40,798 & 77.6 & 0.173 & 31.05 & 111.8 & 0.249 & 44.71 & 66.2 & 0.148 & 26.49 \\
\hline & 3 & 3045 & 250 & 40,798 & 77.6 & 0.173 & 31.05 & 111.8 & 0.249 & 44.71 & 66.2 & 0.148 & 26.49 \\
\hline & 4 & 4163 & 50 & 8,160 & 15.5 & 0.035 & 31.05 & 22.4 & 0.050 & 44.71 & 13.2 & 0.030 & 26.49 \\
\hline $\begin{array}{l}\text { Sunset Drive } \\
\text { The Long }\end{array}$ & 1 & 94138 & 130 & 21,215 & 40.4 & 0.090 & 31.05 & 58.1 & 0.129 & 44.71 & 34.4 & 0.077 & 26.49 \\
\hline Way & 1 & 71873 & 500 & 81,596 & 155.2 & 0.346 & 31.05 & 223.6 & 0.498 & 44.71 & 132.5 & 0.295 & 26.49 \\
\hline TOTAL $^{\mathbf{a}}$ & & & 8,831 & $1,441,151$ & $2,741.9$ & 6.109 & & $3,948.4$ & 8.797 & & $2,339.8$ & 5.213 & \\
\hline
\end{tabular}


Appendix 10. Pumpage at present, planned, and proposed commercial-supply wells on the North Fork, Suffolk County, N.Y., Scenario 4 [Annual total pumpage for 1994 from appendix 4. Well capacity is in gallons per minute. Annual total pumpage is in thousands of gallons. Well identifier between 190000 and 199999 denotes planned well; identifier with number greater than 200,000 denotes proposed well. Well-identifier prefix "S" is omitted.]

\begin{tabular}{|c|c|c|c|c|c|c|c|c|c|c|c|c|c|}
\hline \multirow{4}{*}{$\begin{array}{c}\text { Well } \\
\text { no. }\end{array}$} & \multirow{4}{*}{$\begin{array}{c}\text { Well } \\
\text { use }\end{array}$} & \multirow{4}{*}{$\begin{array}{c}\text { Well } \\
\text { capacity } \\
\text { (gal/min) }\end{array}$} & \multirow{4}{*}{$\begin{array}{c}1994 \text { Annual } \\
\text { total } \\
\text { pumpage } \\
\left(\text { gal } \times 10^{3}\right) \\
\end{array}$} & \multirow{4}{*}{$\begin{array}{c}\text { Annual } \\
\text { total } \\
\text { pumpage } \\
\left(\text { gal } \times 10^{3}\right)\end{array}$} & \multicolumn{9}{|c|}{ Monthly pumping rate } \\
\hline & & & & & \multicolumn{3}{|c|}{ Average annual } & \multicolumn{3}{|c|}{ June through August } & \multicolumn{3}{|c|}{ September through May } \\
\hline & & & & & \multicolumn{2}{|c|}{ Flow rate } & \multirow{2}{*}{$\begin{array}{c}\text { Percent of } \\
\text { capacity }\end{array}$} & \multicolumn{2}{|c|}{ Flow rate } & \multirow{2}{*}{$\begin{array}{c}\text { Percent of } \\
\text { capacity }\end{array}$} & \multicolumn{2}{|c|}{ Flow rate } & \multirow{2}{*}{$\begin{array}{c}\text { Percent of } \\
\text { capacity }\end{array}$} \\
\hline & & & & & $\mathrm{gal} / \mathrm{min}$ & $\mathrm{ft}^{3} / \mathrm{s}$ & & $\mathrm{gal} / \mathrm{min}$ & $\mathrm{ft}^{3} / \mathrm{s}$ & & $\mathrm{gal} / \mathrm{min}$ & $\mathrm{ft}^{3} / \mathrm{s}$ & \\
\hline \multicolumn{14}{|l|}{ Scenario 4} \\
\hline S-11362 & Irrigation & 60 & 1,999 & 3,139 & 6.0 & 0.013 & 9.96 & 8.6 & 0.019 & 14.34 & 5.1 & 0.011 & 8.50 \\
\hline S-11699 & Domestic & 25 & 833 & 1,308 & 2.5 & 0.006 & 9.96 & 3.6 & 0.008 & 14.34 & 2.1 & 0.005 & 8.50 \\
\hline S-26049 & Domestic & 20 & 666 & 1,046 & 2.0 & 0.004 & 9.96 & 2.9 & 0.006 & 14.34 & 1.7 & 0.004 & 8.50 \\
\hline S-31448 & Irrigation & 600 & 19,149 & 30,066 & 57.2 & 0.127 & 9.53 & 82.4 & 0.184 & 13.73 & 48.8 & 0.109 & 8.14 \\
\hline S-33990 & Domestic & 30 & 1,000 & 1,570 & 3.0 & 0.007 & 9.96 & 4.3 & 0.010 & 14.34 & 2.5 & 0.006 & 8.50 \\
\hline S-36799 & General & 200 & 6,665 & 10,465 & 19.9 & 0.044 & 9.96 & 28.7 & 0.064 & 14.34 & 17.0 & 0.038 & 8.50 \\
\hline S-45809 & Domestic & 20 & 666 & 1,046 & 2.0 & 0.004 & 9.96 & 2.9 & 0.006 & 14.34 & 1.7 & 0.004 & 8.50 \\
\hline S-45810 & Domestic & 20 & 666 & 1,046 & 2.0 & 0.004 & 9.96 & 2.9 & 0.006 & 14.34 & 1.7 & 0.004 & 8.50 \\
\hline S-45811 & Domestic & 20 & 666 & 1,046 & 2.0 & 0.004 & 9.96 & 2.9 & 0.006 & 14.34 & 1.7 & 0.004 & 8.50 \\
\hline S-45812 & Domestic & 20 & 666 & 1,046 & 2.0 & 0.004 & 9.96 & 2.9 & 0.006 & 14.34 & 1.7 & 0.004 & 8.50 \\
\hline S-52086 & Industrial & 65 & 1,799 & 2,824 & 5.4 & 0.012 & 8.27 & 7.7 & 0.017 & 11.90 & 4.6 & 0.010 & 7.05 \\
\hline S-84076 & Domestic & 20 & 666 & 1,046 & 2.0 & 0.004 & 9.96 & 2.9 & 0.006 & 14.34 & 1.7 & 0.004 & 8.50 \\
\hline S-93628 & Domestic & 80 & 1,306 & 2,050 & 3.9 & 0.009 & 4.87 & 5.6 & 0.013 & 7.02 & 3.3 & 0.007 & 4.16 \\
\hline S-94491 & Irrigation & 60 & 4,573 & 7,181 & 13.7 & 0.030 & 22.77 & 19.7 & 0.044 & 32.79 & 11.7 & 0.026 & 19.43 \\
\hline S-98991 & Irrigation & 500 & 16,662 & 26,162 & 49.8 & 0.111 & 9.96 & 71.7 & 0.160 & 14.34 & 42.5 & 0.095 & 8.50 \\
\hline S-101947 & Domestic & 20 & 666 & 1,046 & 2.0 & 0.004 & 9.96 & 2.9 & 0.006 & 14.34 & 1.7 & 0.004 & 8.50 \\
\hline Total $^{\mathrm{a}}$ & & 1,760 & 58,652 & 92,090 & 175.2 & 0.390 & & 252.3 & 0.562 & & 149.5 & 0.333 & \\
\hline
\end{tabular}

${ }^{\text {a }}$ Total may not equal the sum of values because of rounding to significant digits. 